\title{
Application of Chelating Agents to Enhance Fenton Process in Soil Remediation: A Review
}

\author{
Alicia Checa-Fernandez (D), Aurora Santos, Arturo Romero and Carmen M. Dominguez *(D) \\ Chemical Engineering and Materials Department, Facultad de Ciencias Químicas, \\ Universidad Complutense de Madrid, Ciudad Universitaria S/N, 28040 Madrid, Spain; \\ crcheca@ucm.es (A.C.-F.); aursan@quim.ucm.es (A.S.); aromeros@quim.ucm.es (A.R.) \\ * Correspondence: carmdomi@ucm.es; Tel.: +91-394-4170
}

Citation: Checa-Fernandez, A.; Santos, A.; Romero, A.; Dominguez, C.M. Application of Chelating Agents to Enhance Fenton Process in Soil Remediation: A Review. Catalysts 2021, 11, 722. https://doi.org/ $10.3390 /$ catal11060722

Academic Editor: Stanisław

Wacławek

Received: 30 April 2021

Accepted: 7 June 2021

Published: 10 June 2021

Publisher's Note: MDPI stays neutral with regard to jurisdictional claims in published maps and institutional affiliations.

Copyright: (c) 2021 by the authors. Licensee MDPI, Basel, Switzerland. This article is an open access article distributed under the terms and conditions of the Creative Commons Attribution (CC BY) license (https:// creativecommons.org/licenses/by/ $4.0 /)$.

\begin{abstract}
Persistent organic contaminants affecting soil and groundwater pose a significant threat to ecosystems and human health. Fenton oxidation is an efficient treatment for removing these pollutants in the aqueous phase at acidic $\mathrm{pH}$. However, the in-situ application of this technology for soil remediation (where $\mathrm{pHs}$ around neutrality are required) presents important limitations, such as catalyst (iron) availability and oxidant $\left(\mathrm{H}_{2} \mathrm{O}_{2}\right)$ stability. The addition of chelating agents (CAs), forming complexes with $\mathrm{Fe}$ and enabling Fenton reactions under these conditions, so-called chelate-modified Fenton process (MF), tries to overcome the challenges identified in conventional Fenton. Despite the growing interest in this technology, there is not yet a critical review compiling the information needed for its real application. The advantages and drawbacks of MF must be clarified, and the recent achievements should be shared with the scientific community. This review provides a general overview of the application of CAs to enhance the Fenton process for the remediation of soils polluted with the most common organic contaminants, especially for a deep understanding of the activation mechanisms and influential factors. The existing shortcomings and research needs have been highlighted. Finally, future research perspectives on the use of CAs in MF and recommendations have been provided.
\end{abstract}

Keywords: chelating agents (CAs); modified Fenton (MF); soil remediation; organic pollutants; $\mathrm{H}_{2} \mathrm{O}_{2}$ stability; reactive oxygen species (ROS); ligand

\section{Introduction}

In recent years, many persistent and toxic contaminants found in soils have attracted the attention of the scientific community. Soil and sediment contamination by organic compounds, resulting from industrial and municipal waste discharge and improper use of chemical fertilizer and pesticides, is a widespread problem worldwide due to its great harm to the ecological environment and public health [1-3]. Nowadays, the principal substances contributing to soil pollution are petroleum oil hydrocarbons (e.g., aliphatic, aromatic, polycyclic aromatic hydrocarbons (PAHs), BTEX (benzene, toluene, ethylbenzene, and xylenes), chlorinated hydrocarbons like polychlorinated biphenyls (PCBs), trichloroethylene (TCE), and perchloroethylene, nitroaromatic compounds, organophosphorus compounds), solvents, and pesticides [4]. In China, $2.5 \%$ of total farmland is too contaminated to be used [5], whereas more than 80,000 sites suffer from soil pollution in the European Union [6]. In this context, the remediation of organic-contaminated soils is crucial, becoming a priority objective for both government institutions and society [3,7].

Extensive work has been devoted to developing soil remediation techniques [8], which mainly involves physical, chemical, and biological processes or/and their combinations. Advanced oxidation processes (AOPs) are powerful chemical methods with growing popularity for organic-contaminated soil remediation, being considered more effective than physical and biological approaches [9]. AOPs are considered capable of oxidizing different classes of organic pollutants by reactive radical species, achieving high levels 
of mineralization [8,9]. The oxidants used in AOPs include hydrogen peroxide $\left(\mathrm{H}_{2} \mathrm{O}_{2}\right)$, persulfate $\left(\mathrm{S}_{2} \mathrm{O}_{8}{ }^{2-}\right)$, permanganate $\left(\mathrm{MnO}_{4}{ }^{-}\right)$, and ozone $\left(\mathrm{O}_{3}\right)$. One of the most frequently AOPs used is the Fenton process $\left(\mathrm{H}_{2} \mathrm{O}_{2}+\mathrm{Fe}(\mathrm{II})\right)$, where $\mathrm{H}_{2} \mathrm{O}_{2}$ is the oxidant species and homogeneous $\mathrm{Fe}(\mathrm{II})$ acts as a catalyst for hydrogen peroxide decomposition $[7,10]$. Alternatively, the catalyst used can be homogeneous Fe(III), giving rise to the Fenton-like process [11]. The interest in using heterogeneous catalysts in the Fenton process (known as catalytic wet peroxide oxidation process, CWPO) has significantly increased in recent times [12]. CWPO uses natural iron-containing materials [12-14], supported catalysts with high surface area-supports (pillared clays, zeolites, silica, activated carbon, etc.), allowing the dispersion of the active phase (mainly Fe, but also $\mathrm{Cu}, \mathrm{Mn}, \mathrm{Au}$, etc.) and metal-free-catalysts (carbonaceous materials) $[15,16]$ to generate highly oxidizing species.

Many recalcitrant organic compounds (e.g., benzene, phenol, PAHs) have been efficiently degraded by the Fenton process and converted into low toxicity compounds [17,18]. The generally accepted mechanism of the Fenton process proposes that the reaction between $\mathrm{Fe}(\mathrm{II})$ and $\mathrm{H}_{2} \mathrm{O}_{2}$ first leads to the formation of hydroxyl radical $\left(\mathrm{OH}^{\bullet}\right.$, redox potential $\mathrm{E}_{0}$ of $2.80 \mathrm{~V}$ ) and $\mathrm{Fe}(\mathrm{III})$ (Equation (1)). Then, the generated Fe(III) can be reduced by reaction with excess hydrogen peroxide, generating $\mathrm{Fe}(\mathrm{II})$ and hydroperoxyl radical $\left(\mathrm{HO}_{2}{ }^{\bullet}\right)$ (Equation (2)). This step allows the regeneration of the catalyst in a cyclic mechanism. Since the regeneration of $\mathrm{Fe}$ (II) (Equation (2)) is several orders of magnitude slower than its oxidation (Equation (1)), it is considered as the rate-limiting step of the reaction chain in catalytic Fenton systems. Once the radical species are formed $\left(\mathrm{OH}^{\bullet}\right.$ and $\left.\mathrm{HO}_{2}{ }^{\bullet}\right)$, they react with organic pollutants ( $\mathrm{RH}$ ) as presented in Equation (3). Moreover, several competitive reactions (radicals recombination, reaction of hydroxyl radicals with hydrogen peroxide and with $\mathrm{Fe}(\mathrm{II})$ ) can also occur (Equations (4)-(7)), negatively affecting the oxidation process [19-23]. The rate constants of these reactions (Equations (4)-(7)) have been reported in the literature [21,24]; as well as the hydroperoxyl radical $\left(\mathrm{HO}_{2}{ }^{\bullet}\right)$ and its conjugated base $\left(\mathrm{O}_{2}{ }^{\bullet-}\right)$ dissociation rate constants (Equation (8)) [25] and $k$ values have been numbered according to their corresponding equation. According to Equations (9)-(11), it should be considered that $\mathrm{O}_{2}{ }^{\bullet-}$ and $\mathrm{HO}_{2}{ }^{\bullet}$ can act as scavengers of the $\mathrm{O}_{2}{ }^{\bullet-}$ formed [26].

$$
\begin{gathered}
\mathrm{Fe}(\mathrm{II})+\mathrm{H}_{2} \mathrm{O}_{2} \rightarrow \mathrm{Fe}(\mathrm{III})+\mathrm{OH}^{\bullet}+\mathrm{OH}^{-} \\
k_{1}=40-80 \mathrm{M}^{-1} \mathrm{~s}^{-1} \\
\mathrm{Fe}(\mathrm{III})+\mathrm{H}_{2} \mathrm{O}_{2} \rightarrow \mathrm{Fe}(\mathrm{II})+\mathrm{HO}_{2} \bullet+\mathrm{H}^{+} \\
k_{2}=9.1 \times 10^{-7} \mathrm{M}^{-1} \mathrm{~s}^{-1} \\
\mathrm{RH}+\mathrm{OH}^{\bullet} \text { or } \mathrm{HO}_{2} \bullet \rightarrow \text { oxidized products } \\
\mathrm{Fe}(\mathrm{II})+\mathrm{OH}^{\bullet} \rightarrow \mathrm{Fe}(\mathrm{III})+\mathrm{OH}^{-} \\
k_{4}=2.5-5 \times 10^{8} \mathrm{M}^{-1} \mathrm{~s}^{-1} \\
\mathrm{H}_{2} \mathrm{O}_{2}+\mathrm{OH}^{\bullet} \rightarrow \mathrm{HO}_{2}^{\bullet}+\mathrm{H}_{2} \mathrm{O} \\
k_{5}=1.7-4.5 \times 10^{7} \mathrm{M}^{-1} \mathrm{~s}^{-1} \\
\mathrm{HO}_{2}^{\bullet}+\mathrm{OH}^{\bullet} \rightarrow \mathrm{O}_{2}+\mathrm{H}_{2} \mathrm{O} \\
k_{6}=1.4 \times 10^{10} \mathrm{M}^{-1} \mathrm{~s}^{-1} \\
\mathrm{OH}^{\bullet}+\mathrm{OH}^{\bullet} \rightarrow \mathrm{H}_{2} \mathrm{O}_{2} \\
k_{7}=5-8 \times 10^{9} \mathrm{M}^{-1} \mathrm{~s}^{-1} \\
\mathrm{HO}_{2} \bullet \leftrightarrow \mathrm{H}^{+}+\mathrm{O}_{2}^{\bullet-} \\
\mathrm{HO}_{2}^{\bullet}+\mathrm{HO}_{2}^{\bullet} \rightarrow \mathrm{H}_{2} \mathrm{O}_{2}+\mathrm{O}_{2} \\
k_{9}=0.8 \times 10^{6} \mathrm{M}^{-1} \mathrm{~s}^{-1} \\
\mathrm{HO}_{2}+\mathrm{O}_{2}^{\bullet-} \stackrel{\mathrm{H}_{2} \mathrm{O}}{\rightarrow} \mathrm{H}_{2} \mathrm{O}_{2}+\mathrm{O}_{2}+\mathrm{OH}^{-} \\
k_{10}=8.5 \times 10^{7} \mathrm{M}^{-1} \mathrm{~s}^{-1}
\end{gathered}
$$




$$
\begin{gathered}
\mathrm{O}_{2}^{\bullet-}+\mathrm{O}_{2}^{\bullet-} \stackrel{2 \mathrm{H}_{2} \mathrm{O}}{\rightarrow} \mathrm{H}_{2} \mathrm{O}_{2}+\mathrm{O}_{2}+2 \mathrm{OH}^{-} \\
k_{11} \leq 100 \mathrm{M}^{-1} \mathrm{~s}^{-1}
\end{gathered}
$$

Although the Fenton process has been proven to be a potentially viable approach for remediating contaminated soils [27-29], there are various limitations associated with this treatment [28]. These limitations, along with possible solutions proposed in the literature, will be examined in the following sections.

\subsection{Major Limitations of Fenton Oxidation in Contaminated Soils}

The Fenton process displays its maximum $\mathrm{OH}^{\bullet}$ production and the subsequent pollutant oxidation activity under acidic $\mathrm{pH}$, in the range $2.8-3.5[19,30,31]$. The system reactivity decreases with increasing $\mathrm{pH}$ above the value of 3.5 due to a decrease in dissolved iron concentration, which precipitates as ferric hydroxide $\left(\mathrm{Fe}(\mathrm{OH})_{3}\right)$ [32]. Moreover, the adsorption of $\mathrm{Fe}(\mathrm{II})$ and $\mathrm{Fe}(\mathrm{III})$ ions onto mineral and organic constituents in the soil increases with the $\mathrm{pH}$ increase [33], resulting in less dissolved Fe available as catalyst for hydrogen decomposition, and consequently, Equation (1) would end. Hence, most of the research on the Fenton process application in aqueous systems has focused on the acidic $\mathrm{pH}$ range [34]. However, subsurface systems are often buffered in the neutral $\mathrm{pH}$ range $(\mathrm{pH}$ 6-8), which greatly complicates the implementation of this process. When treating in situ calcareous soils by the Fenton process, the initial $\mathrm{pH}$ adjustment of the soil by injecting an acid into the subsurface is expensive and impractical because of the buffer capacity of the soil $[8,35,36]$. Moreover, an acidified soil environment may also cause permanent damage to the soil ecosystem, preventing further biological treatments application $[37,38]$.

To ensure the efficient presence of catalysis at neutral $\mathrm{pH}$ despite the low solubility of $\mathrm{Fe}(\mathrm{III})$, iron minerals naturally occurring in soils (normally iron in its oxidized state $\mathrm{Fe}(\mathrm{III}))$ have also been used as catalysts instead of soluble iron (Fe(II)) [39]. The progressive solubilization of the native iron minerals allows the decomposition of $\mathrm{H}_{2} \mathrm{O}_{2}$ and pollutants oxidation in soils without $\mathrm{pH}$ adjustment [22,35]. Similarly, heterogeneous Fenton reactions can effectively degrade refractory organic pollutants in soils at even circumneutral $\mathrm{pH}$ ranges [19]. Another possibility to overcome the constraint mentioned above is to deliver a soluble inorganic or organic ligand (also named chelating agent, CA) to maintain iron in the solution, enhancing the Fenton reactions. This process is called chelate-modified Fenton (MF; $\mathrm{Fe}(\mathrm{II}) / \mathrm{Fe}(\mathrm{III})+\mathrm{H}_{2} \mathrm{O}_{2}+\mathrm{CA}$ ) process. Inorganic and organic CAs form complexes with $\mathrm{Fe}(\mathrm{II}) / \mathrm{Fe}$ (III) at neutral $\mathrm{pH}$, keep it soluble, and thus enhance the production of oxidative species and extend the applicability of Fenton oxidation to a wider range of $\mathrm{pH}[28,40,41]$. The extraction of the transition metals of the soil is also enhanced by the addition of chelating agents [42]. Furthermore, some authors proposed that CAs can also improve the persistence of $\mathrm{H}_{2} \mathrm{O}_{2}$, allowing the radical species generated to flow through the soil, reaching the target contaminants [9]. Thus, CAs addition has practical implications for enhancing the Fenton and Fenton-like processes in soil remediation. The main characteristics of the chelating agents applied in Fenton process have been summarized in Table 1 (Section 2.3).

\subsection{Use of Chelating Agents in Soil Remediation by Modified Fenton Process: Reaction Mechanism}

A simplified reaction mechanism showing the reversible binding between the ligand and iron ( $\mathrm{Fe}(\mathrm{II}) / \mathrm{Fe}(\mathrm{III})$ ), which results in the formation of a complex (expressed as $\mathrm{Fe}(\mathrm{II})-\mathrm{L}$ and $\mathrm{Fe}(\mathrm{III})-\mathrm{L}$, respectively), is proposed in Equations (12) and (13). It should be considered that the complexation of Fe species with ligands is more complicated than shown, and a wide variety of complexes, such as $\mathrm{FeL}_{2}$, FeHL, $\mathrm{FeHL}_{2}$, etc., can be formed. Their generation depends on several factors, such as the type of CA used, the CA:Fe molar ratio, and the $\mathrm{pH}$, among others. For simplicity, $\mathrm{Fe}(\mathrm{II}) / \mathrm{Fe}(\mathrm{III})-\mathrm{L}$ (abbreviated as Fe-L) is used to represent 
all the forms of the possible complexes formed between the ligand corresponding to each $\mathrm{CA}$ and $\mathrm{Fe}$, which stability constants have been summarized in Table 2 .

$$
\begin{aligned}
& \mathrm{Fe}(\mathrm{II})+\mathrm{L} \rightleftarrows \mathrm{Fe}(\mathrm{III})-\mathrm{L} \\
& \mathrm{Fe}(\mathrm{III})+\mathrm{L} \rightleftarrows \mathrm{Fe}(\mathrm{III})-\mathrm{L}
\end{aligned}
$$

In a simplified reaction scheme of chelate-modified Fenton (MF), the Fe-L complexes formed (Equations (12) and (13)) would decompose $\mathrm{H}_{2} \mathrm{O}_{2}$ to generate radical species (hydroxyl and hydroperoxyl radicals) (Equations (14) and (15)), equivalent to classical Fenton reactions (Equations (1) and (2), respectively), being the catalytic regeneration (Equation (15)) the limiting stage of the process. However, in the presence of most organic CAs, it has been suggested that $\mathrm{H}_{2} \mathrm{O}_{2}$ was unlikely to reduce complexed iron, and the reduction of $\mathrm{Fe}(\mathrm{III})-\mathrm{L}$ was mainly produced through $\mathrm{O}_{2}{ }^{\bullet-}$ generated (Equation (18)) rather than from the direct Fenton reactions with $\mathrm{H}_{2} \mathrm{O}_{2}$ (Equation (15)) [26,43-47]. In this way, the MF acceleration is attributed to the positive effect of $\mathrm{O}_{2}{ }^{-}$- during regeneration of $\mathrm{Fe}(\mathrm{II})-\mathrm{L}$ from $\mathrm{Fe}(\mathrm{III})-\mathrm{L}$. Following the catalytic cycle, the reduced $\mathrm{Fe}(\mathrm{II})-\mathrm{L}$ can be reoxidized by $\mathrm{H}_{2} \mathrm{O}_{2}$ (Equation (14)), reactive species $\left(\mathrm{HO}_{2} \bullet / \mathrm{O}_{2}^{\bullet-}\right.$ ) (Equation (16)) or $\mathrm{O}_{2}$ (Equation (17)). The nomenclature of the kinetic constants corresponding to each reaction has been included. The values of these constants are listed in Table 3 (Section 2.4).

$$
\begin{gathered}
\mathrm{Fe}(\mathrm{II})-\mathrm{L}+\mathrm{H}_{2} \mathrm{O}_{2} \rightarrow \mathrm{Fe}(\mathrm{III})-\mathrm{L}+\mathrm{OH}^{\bullet}+\mathrm{OH}^{-} \\
{\left[k_{\mathrm{Fe}(\mathrm{II})-\mathrm{L}, \mathrm{H} 2 \mathrm{O} 2}\right]} \\
\mathrm{Fe}(\mathrm{III})-\mathrm{L}+\mathrm{H}_{2} \mathrm{O}_{2} \rightarrow \mathrm{Fe}(\mathrm{II})-\mathrm{L}+\mathrm{H}^{+}+\mathrm{HO}_{2} \bullet \\
{\left[k_{\mathrm{Fe}(\mathrm{III})-\mathrm{L}, \mathrm{H} 2 \mathrm{O} 2}\right]} \\
\mathrm{Fe}(\mathrm{II})-\mathrm{L}+\mathrm{HO}_{2} \bullet / \mathrm{O}_{2} \bullet-\rightarrow \mathrm{Fe}(\mathrm{III})-\mathrm{L}+\mathrm{H}_{2} \mathrm{O}_{2} \\
{\left[k_{\mathrm{Fe}(\mathrm{II})-\mathrm{L}, \mathrm{O} 2}^{\bullet}\right]} \\
\mathrm{Fe}(\mathrm{II})-\mathrm{L}+\mathrm{O}_{2} \rightarrow \mathrm{Fe}(\mathrm{III})-\mathrm{L}+\mathrm{O}_{2} \bullet- \\
\mathrm{Fe}(\mathrm{III})-\mathrm{L}+\mathrm{HO}_{2} \bullet / \mathrm{O}_{2} \bullet-\rightarrow \mathrm{Fe}(\mathrm{II})-\mathrm{L}+\mathrm{O}_{2} \\
{\left[k_{\mathrm{Fe}(\mathrm{III})-\mathrm{L}, \mathrm{O}^{\bullet}}--\right]}
\end{gathered}
$$

In the MF system, different reactive oxygen species (ROS) can be responsible for the degradation of organic contaminants, being the main types: hydroxyl radical $\left(\mathrm{OH}^{\bullet}\right)$, superoxide radical $\left(\mathrm{O}_{2}{ }^{\bullet-}\right)$ (and its conjugated base, hydroperoxyl radical $\left(\mathrm{HO}_{2}{ }^{\bullet}\right)$ ), and high-valent iron species [48]. Indeed, there has been considerable debate as to whether the main ROS in the MF process are hydroxyl radicals or higher oxidation states of iron (such as Fe(IV) or ferryl (FeO) ${ }^{2+}$ complexes) (Equations (19)-(22)) [49]. In the presence of some CAs, rather than the direct generation of hydroxyl radicals (Equation (14)), the initial step is likely the formation of a ferrous peroxide (Fe(IV)) complex (Equation (19)). This complex can convert to ferryl species (Equation (20)), breakdown to give hydroxyl radicals (Equation (21)), or directly oxidize an organic substrate. Thus, in different circumstances, one or all three of the reactive species (or the combination of them) may oxide the organic pollutants (RH) (Equation (22)).

$$
\begin{gathered}
\mathrm{Fe}(\mathrm{II})-\mathrm{L}+\mathrm{H}_{2} \mathrm{O}_{2} \rightarrow \mathrm{Fe}(\mathrm{IV})-\mathrm{L} \\
\mathrm{Fe}(\mathrm{IV})-\mathrm{L} \rightarrow(\mathrm{FeOL})^{4+}+\mathrm{H}_{2} \mathrm{O} \\
\mathrm{Fe}(\mathrm{IV})-\mathrm{L} \rightarrow \mathrm{Fe}(\mathrm{III})-\mathrm{L}+\mathrm{OH}^{\bullet}+\mathrm{OH}^{-} \\
\mathrm{RH}+\mathrm{OH}^{\bullet} \text { or } \mathrm{HO}_{2}{ }^{\bullet} \mathrm{O}_{2} \bullet-\text { or Fe(IV)-L } /(\mathrm{FeOL})^{4+} \rightarrow \text { oxidized products }
\end{gathered}
$$

As mentioned above, the addition of CAs in the Fenton process allows the extent of its $\mathrm{pH}$ application range to approximately neutral conditions and decreases oxidant consumption [50]. However, the use of CAs has some disadvantages that must be considered 
before its implementation. CA and pollutant can compete for the hydroxyl radicals (or the other reactive species) formed with a significant loss of the process efficiency [51]. In this regard, the scavenger effect of the CA should be considered. The reactions between Fe-L and ligands (L) with $\mathrm{OH}^{\bullet}$ are reflected in Equations (23) and (24), respectively.

$$
\begin{array}{r}
\mathrm{Fe}(\mathrm{II})-\mathrm{L} / \mathrm{Fe}(\mathrm{III})-\mathrm{L}+\mathrm{OH}^{\bullet} \rightarrow \text { oxidized products } \\
{\left[k_{\left.\mathrm{Fe}-\mathrm{L}, \mathrm{OH}^{\bullet}\right]}\right.} \\
\mathrm{L}+\mathrm{OH}^{\bullet} \rightarrow \underset{\text { oxidized products }}{ }\left[k_{\left.\mathrm{L}, \mathrm{OH}^{\bullet}\right]}{ }^{\bullet}\right.
\end{array}
$$

Even though the possible oxidation of ligands by the radical species generated is of great importance, this aspect has not been deeply analyzed in the literature, where attention has been mostly paid to the pollutant abatement. The $\mathrm{OH}^{\bullet}$ or other reactive species yield in the MF process depends on the $\mathrm{pH}$ value, the $\mathrm{H}_{2} \mathrm{O}_{2}$ : $\mathrm{Fe}$ ratio, and the $\mathrm{CA}$ :Fe ratio [52]. Moreover, when choosing the $\mathrm{CA}$, different factors, such as the contaminant accessibility, soil matrix content, soil texture and moisture, the adsorption of the catalyst and the CA onto the soil, intraparticle diffusion and removal of chemicals added by leaching can significantly affect the contaminant removal, and thus, should be considered. In the same direction, it should be considered that the type of soil will determine the kinetics of the process and even the mechanism scheme.

Applying different $\mathrm{CAs}$ to make iron soluble at circumneutral $\mathrm{pH}$ (as catalyst for hydrogen peroxide decomposition) has been recently reviewed for Fenton and photo-Fenton processes in the aqueous phase [32,40,41]. The authors affirmed that the contaminants are efficiently degraded by this process (MF), highlighting a potential treatment approach for the degradation of different pollutants (including emerging contaminants, aromatic compounds, pesticides, dyes, etc.) at neutral $\mathrm{pH}$.

However, to the best of our knowledge, a critical review illustrating the use of different chelating agents in Fenton treatment for soil remediation is still missing in the literature. Thus, this article reviews the most common CAs and their employment for soil remediation by the Fenton process (MF process). Four aspects have been considered: the main characteristics of the CAs, the stability constants of the Fe-L complexes formed (Fe(II)-L and $\mathrm{Fe}(\mathrm{III})-\mathrm{L}$, respectively), the reaction mechanism of $\mathrm{Fe}(\mathrm{II})-\mathrm{L}$ oxidation (and potentially $\mathrm{Fe}(\mathrm{III})$ - $\mathrm{L}$ reduction) in the presence of different ligands, and the negative hydroxyl radical scavenger effect of the ligand. Finally, this review analyzes the results obtained when using different $\mathrm{CAs}$ to enhance the Fenton process in soil remediation, giving practical information on which type of CA to use depending on the pollutant type and the real matrix soil's characteristics. Moreover, this review has identified the unexplored areas in this topic which will give readers insight into future studies.

\section{Chelating Agents Commonly Used in Modified Fenton Process for Soil Remediation}

Many compounds strongly complex with Fe and, therefore, can be used as chelating agents in the MF process. CAs used in soil remediation may be classified into inorganic and organic compounds. The most used inorganic compound is pyrophosphate (PPP). Among organic CAs, three main types may be considered according to their coordination sites: polycarboxylates (citrate (in the form of citric acid (CitrA) or its salt) and oxalate (in the form of oxalic acid (OA) or its salt), aminocarboxylates (ethylenediaminetetraacetic acid (EDTA), nitrilotriacetic acid (NTA), ethylenediamine-N,N'-disuccinic acid (EDDS), ethylenediamine-N,N'-bis(2-hydroxyphenyl)acetic acid (EDDHA)) and humic substances (humic (HA) and fulvic acids (FA)). The structure of the CAs most used for the remediation of soils contaminated with organic pollutants, and therefore considered in this review, is summarized Figure 1. 
1. INORGANIC CHELATING AGENTS

a) PPP<smiles>O=P(O)(O)OP(=O)(O)O</smiles>

2. ORGANIC CHELATING AGENTS

Polycarboxylic acids

b) CitrA<smiles>O=C(O)CC(O)(CC(=O)O)C(O)=[14C]C(=O)O</smiles>

c) $\mathrm{OA}$<smiles>O=C(O)C(=O)O</smiles>

Aminopolycarboxylic acids

d) EDTA<smiles>O=C(O)CN(CCN(CC(=O)O)CC(=O)O)CC(=O)O</smiles>

f) EDDS<smiles>O=C(O)CC(NCCNC(CC(=O)O)C(=O)O)C(=O)O</smiles>

e) NTA<smiles>O=C(O)CN(CC(=O)O)CC(=O)O</smiles>

g) EDDHA

Figure 1. Structure of the investigated chelating agents: (1) inorganics; (a) pyrophosphate (PPP), and (2) organics; (b) citrate as citric acid (CitrA), (c) oxalate as oxalic acid (OA), (d) ethylenediaminetetraacetic (EDTA), (e) nitriloacetic acid (NTA), (f) ethylenediamine-N,N'-disuccinic acid (EDDS) and (g) ethylenediamine-N,N'-bis(2-hydroxyphenyl)acetic acid (EDDHA).

In addition to the CAs above-mentioned, other organics CAs less frequently used for soil remediation are catechol (CC), 1-Ascorbic acid (1-AA), gallic acid (GA), picolinic acid (PA), sodium N,N'-bis(carboxymethyl) glutamic acid (GLDA), and cyclodextrins (CD).

The capability of a single ligand to form strong complexes with Fe is essential to prevent the precipitation of Fe(III) as iron hydroxide [32]. The binding Fe-L influences the characteristics and reactivity of the complex with substrates [53]. The stability constant of $\mathrm{Fe}(\mathrm{II})-\mathrm{L}$ and $\mathrm{Fe}(\mathrm{III})$-L is defined as the equilibrium constant for the complex formation in solution (Equations (12) and (13)), and it indicates the strength of the interaction between CAs and Fe. The complex formation equilibria can be written as the sum of each stage (generation of $\mathrm{ML}, \mathrm{ML}_{2}, \mathrm{ML}_{3}$, etc.), giving rise to overall stability constants $(\beta)$. Except for the first stage (ML), in which $\beta_{1}$ corresponds to $K_{1}$, the overall stability constants are 
products of the successive formation constants of each of the stages. CAs with lower stability constants (expressed as its logarithmic value, $\log \beta$ ) would need higher CA:Fe molar ratios to form stable Fe-L complexes. The higher the stability constant of a complex is, the higher the tendency of forming the Fe-L complex will be. In this way, higher stability constants of $\mathrm{Fe}(\mathrm{III})-\mathrm{L}$ than $\mathrm{Fe}(\mathrm{II})-\mathrm{L}$ suggested higher reaction rates of $\mathrm{Fe}(\mathrm{II})-\mathrm{L}$ with $\mathrm{H}_{2} \mathrm{O}_{2}$ (Equation (14)), and accordingly, lower reduction rates of Fe(III)-L to Fe(II)-L (Equation (15) or Equation (18)) [41].

Another interesting feature of each CA is its acid ionization constant values $(p K a) . p K a$ is a quantitative measure of the strength of an acid that dissociates into the conjugate base and a hydrogen ion $\left(\mathrm{H}^{+}\right)$. Depending on the charges, each ligand will have corresponding $p K a$ values, e.g., a poliprotonic CA with four protons will have four $p K a$ values, corresponding to Equations (25)-(28). $p K a$ values represent the tendency of the donor atoms of the ligand to donate electrons to metal atoms: thus, directly affecting the Fe-L formation, and consequently, the stability constant. The lower the value of $p K a$ is, the stronger the acid is. The addition of CAs with low $p K a$ values will tend to decrease the $\mathrm{pH}$ of the Fenton system, and it would correspond with lower stability constants of Fe-L complexes [41].

$$
\begin{gathered}
\mathrm{H}_{4} \mathrm{~L} \leftrightarrow \mathrm{H}_{3} \mathrm{~L}^{-}+\mathrm{H}^{+} p k a_{1} \\
\mathrm{H}_{3} \mathrm{~L}^{-} \leftrightarrow \mathrm{H}_{2} \mathrm{~L}^{2-}+\mathrm{H}^{+} p k a_{2} \\
\mathrm{H}_{2} \mathrm{~L}^{2-} \leftrightarrow \mathrm{HL}^{3-}+\mathrm{H}^{+} p k a_{3} \\
\mathrm{HL}^{3-} \leftrightarrow \mathrm{L}^{4-}+\mathrm{H}^{+} p k a_{4}
\end{gathered}
$$

The Fe-L formed will depend on the reaction conditions, such as CA:Fe molar ratio and $\mathrm{pH}$. Therefore, a systematic review of each ligand, including its main characteristics, the Fe-L formation, the reaction mechanisms between $\mathrm{Fe}-\mathrm{L}$ and $\mathrm{H}_{2} \mathrm{O}_{2}$, the reactive species generated in the system and their role in contaminant degradation, has been carried out in the following subsections. However, it should be considered that the chemical kinetics and mechanism controlled by stoichiometry can vary significantly depending on the type of soil treated and its characteristics, as further detailed in Section 3.1.

\subsection{Inorganic Chelating Agents: Pyrophosphate}

Pyrophosphate (PPP) contains two dentates, as can be seen in Figure 1. PPP, in the form of sodium pyrophosphate (SP), is the most used inorganic CA for iron stabilization in Fenton type systems [54-58]. Moreover, the addition of SP has shown an oxidant stabilizer effect, slowing down its decomposition [54,56,59]. The Fe-L formed between Fe and SP are $\mathrm{Fe}\left(\mathrm{HP}_{2} \mathrm{O}_{7}\right)_{2}{ }^{3-}$, in the $\mathrm{pH}$ range of $2-8$, and $\mathrm{Fe}(\mathrm{OH})_{2} \mathrm{P}_{2} \mathrm{O}_{7}{ }^{3-}$, at $\mathrm{pH}>8[59,60]$.

Contradictory results have been found in the literature regarding the $\mathrm{Fe} / \mathrm{PPP} / \mathrm{H}_{2} \mathrm{O}_{2}$ mechanism. Ma et al. proposed a plausible reaction mechanism for the degradation of organic compounds by MF in the presence of PPP (in the form of SP), as shown in Figure 2, where the main reactions of the process are schematized (adapted from $\mathrm{Ma}$ et al. [56]). Fe(III)-PPP is reduced to Fe(II)-PPP by hydrogen peroxide. The authors found that $\mathrm{O}_{2}{ }^{\bullet-}$ and $\mathrm{OH}^{\bullet}$ contributed to the degradation of polychlorinated biphenyls (PCBs) by 10\% and 90\%, respectively [56]. Rachmilovich-Calis et al. determined the rate constant of $\mathrm{Fe}(\mathrm{II})-\mathrm{PPP}$ with $\mathrm{H}_{2} \mathrm{O}_{2}$ (Equation (14)), which was at least 20 times higher than in the absence of ligands [53] (see Table 3, Section 2.4, where the kinetic constants of the different reactions involved in MF process have been summarized). However, Fischbacher et al. suggested that $\mathrm{Fe}(\mathrm{III})$-PPP did not react with $\mathrm{H}_{2} \mathrm{O}_{2}$ (Equation (15)), and thus, catalyst regeneration is not produced [52]. This finding is in accordance with the high stability constant of Fe(III)-PPP (included in Table 2, Section 2.3, where the main properties of the CAs studied have been summarized), which favors the oxidation of $\mathrm{Fe}(\mathrm{II})-\mathrm{PPP}$ to $\mathrm{Fe}(\mathrm{III})-\mathrm{PPP}$ by $\mathrm{H}_{2} \mathrm{O}_{2}$ (Equation (14)) while dramatically hinders the reduction of Fe(III)-PPP to Fe(II)-PPP (Equation (15) or Equation (18)) [44,59]. Although some authors supported that the reduction of Fe(III)-PPP was limited, the delays in the rate of $\mathrm{H}_{2} \mathrm{O}_{2}$ 
decomposition, the increase in $\mathrm{OH}^{\bullet}$ production and the amount of soluble iron, lead to an increase in pollutant conversion when this ligand is used in soil remediation under near-neutral conditions [54-56,59]. Furthermore, a positive aspect of PPP is its inorganic nature. The scavenging effect of this $\mathrm{CA}$ can be neglected due to the low reactivity of $\mathrm{OH}^{\bullet}$ towards $\mathrm{P}_{2} \mathrm{O}_{7}{ }^{4-}$, compared to other organic CAs (see Table 3) [61]. In addition, after its hydrolysis to orthophosphate, PPP can serve as phosphorus fertilizer to plants and environmental microorganisms [59,62], facilitating a subsequent bioremediation treatment after the application of the MF process.

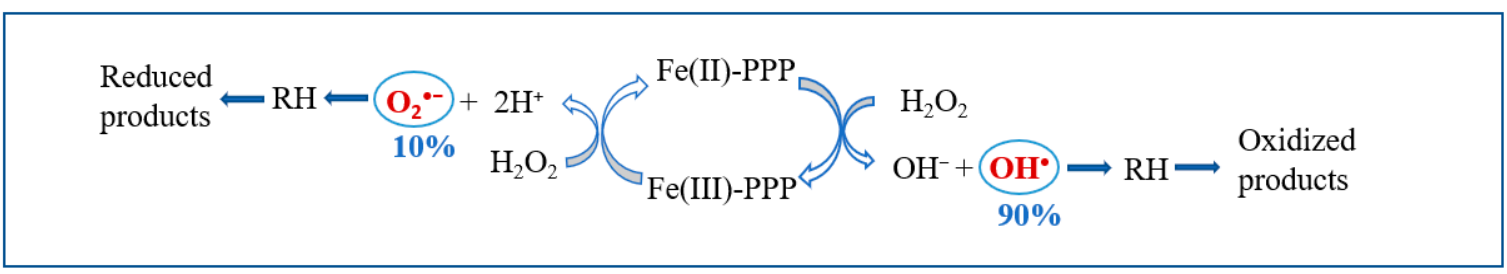

Figure 2. Simplified mechanism of organic pollutant degradation (RH) in the $\mathrm{Fe} / \mathrm{PPP} / \mathrm{H}_{2} \mathrm{O}_{2}$ system. Adapted from Ma et al. [56].

On the other hand, factors such as $\mathrm{CA}: \mathrm{Fe}$ and $\mathrm{H}_{2} \mathrm{O}_{2}$ :Fe ratios can decisively influence the process efficiency and therefore, they should be considered. In this way, it has been reported that the combination of $\mathrm{Fe}$ (II) with an equal molar amount of PPP enhanced the production of $\mathrm{OH}^{\bullet}$ [63], while the use of PPP concentrations considerably higher ([CA] $>>$ [Fe]) decreased the yield of hydroxyl radicals formed [52]. In this case, the strong steric hindrance by PPP impeded the interaction between $\mathrm{H}_{2} \mathrm{O}_{2}$ and the catalyst [61] .

\subsection{Organic Chelating Agents}

2.2.1. Polycarboxylic acids (PCAs)

Citrate/Citric acid (CitrA)

Citrate ligand can be generated from citric acid (CitrA) or sodium salts, such as sodium citrate mono-hydrate $\left(\mathrm{SC}_{\mathrm{m}}\right)$ and trisodium citrate $(\mathrm{SC})$. CitrA is an environmentalfriendly ligand consisting of three carboxyl groups and one hydroxyl group (Figure 1). This tricarboxylic acid has relatively low $p K a$ values (Table 2, Section 2.3). Thus, its addition tends to decrease the $\mathrm{pH}$ of the reaction mixture. The $\mathrm{pH}$ decline can be associated to a possible dramatic ecological impact on the soil, and, therefore, the use of CitrA should be carefully evaluated. To avoid this effect and maintain the natural $\mathrm{pH}$ of the soils, sodium salts $\left(\mathrm{SC}_{\mathrm{m}}\right.$ and $\mathrm{SC}$ ) which act as a buffer, can be used instead of CitrA [35]. The ligand citrate interacts with Fe to generate the complex Fe-citrate. The reaction of Fe(II)-citrate with $\mathrm{H}_{2} \mathrm{O}_{2}$ at neutral $\mathrm{pH}$ has been illustrated in a simplified scheme (Figure 3, adapted from Zeng et al. [64]), where the main reactions involved in the process have been schematized.

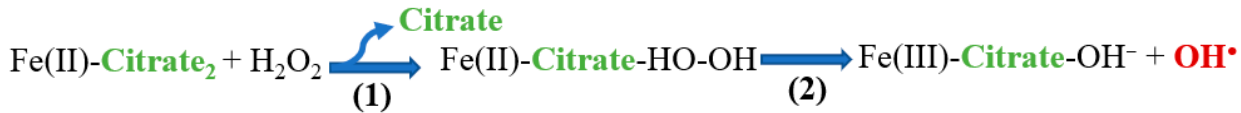

Figure 3. Simplified scheme of MF mechanism in the presence of citrate. Adapted from Zeng et al. [64].

In this reaction, $\mathrm{H}_{2} \mathrm{O}_{2}$ substitutes a citrate ligand from $\mathrm{Fe}(\mathrm{II})$-citrate 2 to form $\mathrm{Fe}(\mathrm{II})$ citrate- $\mathrm{H}_{2} \mathrm{O}_{2}$ (step 1). The ligand-exchange rate determines this reaction and thus is the ratelimiting step. Then, an intramolecular transfer from the $\mathrm{Fe}(\mathrm{II})$ to the $\mathrm{H}_{2} \mathrm{O}_{2}$ bound occurs, producing $\mathrm{Fe}(\mathrm{III})$-citrate-OH${ }^{-}$and hydroxyl radicals (step 2), much faster than step 1 [64]. Adversely, the kinetic model proposed by Miller et al. supported that superoxide radicals 
$\left(\mathrm{O}_{2}{ }^{\bullet-}\right)$ are produced by the reaction between Fe(II)-citrate and oxygen (Equation (29)). After that, the $\mathrm{Fe}(\mathrm{III})$-citrate is reduced by $\mathrm{O}_{2}{ }^{\bullet-}$ (Equation (30)) [25].

$$
\begin{aligned}
& \mathrm{Fe}(\mathrm{II}) \text {-citrate }+\mathrm{O}_{2} \rightarrow \mathrm{Fe}(\mathrm{III}) \text {-citrate }+\mathrm{O}_{2}{ }^{\bullet-} \\
& \mathrm{Fe}(\mathrm{III}) \text {-citrate }+\mathrm{O}_{2}{ }^{\bullet-} \rightarrow \mathrm{Fe}(\mathrm{II}) \text {-citrate }+\mathrm{O}_{2}
\end{aligned}
$$

The ability to maintain $\mathrm{Fe}$ in solution in the $\mathrm{Fe} /$ citrate $/ \mathrm{H}_{2} \mathrm{O}_{2}$ system depends on the reaction $\mathrm{pH}$ and the reagents molar ratio. Soluble $\mathrm{Fe}(\mathrm{III})$-citrate complexes are formed at $\mathrm{pH}$ above 3.0, and iron dramatically precipitates at $\mathrm{pH}>7$ [32,65]. At low citrate:Fe molar ratios and low $\mathrm{pH}$ values, the speciation of these systems is dominated by the dinuclear and trinuclear complexes $\left(\mathrm{Fe}_{2} \mathrm{~L}_{2}\right.$ and $\mathrm{Fe}_{3} \mathrm{~L}_{3}$, respectively) [66]. However, at low citrate:Fe molar ratios and neutral $\mathrm{pH}$, each iron atom binds with two citrate ligand to form the mononuclear dicitrate complex $\left(\mathrm{FeL}_{2}\right)$ [67]. Moreover, the reaction $\mathrm{pH}$ and the CA:Fe molar ratio also affects the amount of the oxidizing species generated in the system [68]. The oxidation of $\mathrm{Fe}(\mathrm{II})$-citrate resulted in substantial $\mathrm{OH}^{\bullet}$ production, and a rate constant of the $\mathrm{Fe}(\mathrm{II})$-citrate reaction with $\mathrm{H}_{2} \mathrm{O}_{2}\left(k_{\mathrm{Fe}(\mathrm{II})-\mathrm{L}, \mathrm{H} 2 \mathrm{O} 2}\right.$, Equation (14)) of $4.0 \times 10^{3} \mathrm{M}^{-1} \mathrm{~s}^{-1}$ has been reported $[25,69]$. The reaction rate constant obtained is in accordance with those obtained elsewhere [64,69] (included in Table 3, Section 2.4).

Zepp et al. [70] determined the reactivity of citrate with $\mathrm{OH}^{\bullet}$, suggesting relatively high values for the kinetic constant $\left(k_{\text {citrate, }} \mathrm{OH}^{\bullet}, \mathrm{M}^{-1} \mathrm{~s}^{-1}\right)$ (Equation (24))) at $25^{\circ} \mathrm{C}$, depending on the reaction $\mathrm{pH}: 1.2 \times 10^{8}(\mathrm{pH}=3.0), 1.5 \times 10^{8}(\mathrm{pH}=3.6), 2.4 \times 10^{8}(\mathrm{pH}=6.0)$, and $3.2 \times 10^{8}(\mathrm{pH}=6.6)$. The increase in reactivity with $\mathrm{pH}$ is attributable to the citrate deprotonation (as CitrA) to its more reactive dissociated species [70]. These authors estimated that the hydroxyl radical scavenging rate constant for the Fe-L complex $\left(k_{F e-c i t r a t e, ~} \mathrm{OH}^{\bullet}\right)$ was $1.2 \times 10^{8} \mathrm{M}^{-1} \mathrm{~s}^{-1}$ (Equation (23), Table 3, Section 2.4). Thus, the high-rate constant of citrate and Fe-citrate towards $\mathrm{OH}^{\bullet}$ radicals lead to a significant scavenging effect (related to low pollutants degradation) at a high dose of this ligand. However, the relatively low stability constant of Fe-citrate (especially when CitrA is used, Table 3, Section 2.3) requires high proportions of this ligand to chelate the catalyst [41]. In this way, the concentration of citrate should be high enough to favor the formation of the Fe-citrate complex but not so high as to cause a significant scavenging effect on the $\mathrm{OH}^{\bullet}$ radicals produced. For all of the above, it can be concluded that $\mathrm{pH}$ and citrate:Fe molar ratio has a decisive influence on the effectiveness of using this ligand in a MF process for soil remediation [71].

On the other hand, Fe-citrate complexes produce a significant stabilization effect of $\mathrm{H}_{2} \mathrm{O}_{2}[35,72,73]$. For example, Vicente et al. reported that citrate, both as CitrA and citrate salts $\left(\mathrm{SC}_{\mathrm{m}}\right.$ and $\mathrm{SC}$ ), reduced the $\mathrm{H}_{2} \mathrm{O}_{2}$ conversion significantly, following a decreasing order at $1 \mathrm{~h}$ of reaction time: no citrate addition $(75 \%)>\mathrm{SC}(60 \%)>\mathrm{SC}_{\mathrm{m}}(50 \%)>\operatorname{CitrA}(20 \%)$ [35].

\section{Oxalate/Oxalic Acid (OA)}

The ligand oxalate is mainly used as oxalic acid $\left(\left(\mathrm{C}_{2} \mathrm{O}_{4}\right)^{2-}, \mathrm{OA}\right)$. OA is the simplest existing dicarboxylic acid and has been widely used to enhance the Fenton process for soil remediation $[55,57,74,75]$. In the MF process, $\mathrm{OA}$ binds to the iron ion to form Fe-oxalate (Fe(III) $\left(\mathrm{C}_{2} \mathrm{O}_{4}\right)^{2-}$ [76]). This facilitates the reduction of ferric ion to ferrous ion by $\mathrm{H}_{2} \mathrm{O}_{2}$ (Equation (31)). Meanwhile, $\mathrm{Fe}(\mathrm{III})-\mathrm{OA}$ can also be reduced by superoxide $\left(\mathrm{O}_{2}{ }^{\bullet}\right)$ and hydroperoxyl $\left(\mathrm{HO}_{2}{ }^{\bullet}\right)$ radicals (Equation (32)). The catalyst regeneration (giving rise to $\mathrm{Fe}(\mathrm{III})-\mathrm{OA}$ ) contributes to the decomposition of $\mathrm{H}_{2} \mathrm{O}_{2}$ and generation of hydroxyl radicals (Equation (33)) [76]. In addition, oxalate can react with dissolved oxygen to form superoxide radicals $\left(\mathrm{O}_{2}{ }^{\bullet}\right)$ (Equation (34)), which in turn can produce $\mathrm{H}_{2} \mathrm{O}_{2}$ according to Equation (35). In this way, the hydrogen peroxide generated can yield more hydroxyl radicals [45]. Thus, oxalate enhances the production of hydroxyl radicals. The following scheme has been proposed by Wang et al. [76].

$$
\begin{gathered}
\mathrm{Fe}(\mathrm{III})-\left(\mathrm{C}_{2} \mathrm{O}_{4}\right)^{2-}+\mathrm{H}_{2} \mathrm{O}_{2} \rightarrow \mathrm{Fe}(\mathrm{II})-\left(\mathrm{C}_{2} \mathrm{O}_{4}\right)^{2-}+\mathrm{HO}_{2} \bullet \\
\mathrm{Fe}(\mathrm{III})-\left(\mathrm{C}_{2} \mathrm{O}_{4}\right)^{2-}+\mathrm{HO}_{2} \bullet / \mathrm{O}_{2}^{\bullet-} \rightarrow \mathrm{Fe}(\mathrm{II})-\left(\mathrm{C}_{2} \mathrm{O}_{4}\right)^{2-}+\mathrm{O}_{2}
\end{gathered}
$$




$$
\begin{gathered}
\mathrm{Fe}(\mathrm{II})-\left(\mathrm{C}_{2} \mathrm{O}_{4}\right)^{2-}+\mathrm{H}_{2} \mathrm{O}_{2} \rightarrow \mathrm{Fe}(\mathrm{III})-\left(\mathrm{C}_{2} \mathrm{O}_{4}\right)^{+}+\mathrm{OH}^{\bullet}+\mathrm{OH}^{-} \\
\mathrm{C}_{2} \mathrm{O}_{4}^{\bullet}+\mathrm{O}_{2} \rightarrow 2 \mathrm{CO}_{2}+\mathrm{O}_{2}^{\bullet} \\
\mathrm{HO}_{2} \bullet / \mathrm{O}_{2}^{\bullet-}+\mathrm{H}^{+} \rightarrow \mathrm{H}_{2} \mathrm{O}_{2}+\mathrm{O}_{2}
\end{gathered}
$$

The rate constant for the Fenton reaction (Equation (1)) in the absence of ligands is around 40-80 M-1 $\mathrm{s}^{-1}$, whereas this value increases up to $3.1 \times 10^{4} \mathrm{M}^{-1} \mathrm{~s}^{-1}$ when the decomposition of $\mathrm{H}_{2} \mathrm{O}_{2}$ is catalyzed by $\mathrm{Fe}(\mathrm{II})$-oxalate, which is 3 orders of magnitude higher $[77,78]$.

Moreover, OA (and its dissociated species) can be considered almost unreactive with hydroxyl radicals $\left(k_{\text {oxalate, }} \mathrm{OH}^{\bullet}\right.$ values in the range of $1.4 \times 10^{6} \mathrm{M}^{-1} \mathrm{~s}^{-1}[79]-1 \times 10^{7} \mathrm{M}^{-1}$ $\mathrm{s}^{-1}$ [70]) compared to other organic CAs, such as citrate, EDTA and EDDS (the kinetic constant between OA and hydroxyl radicals is 1 or 2 orders of magnitude lower than the corresponding to other CAs, as can be seen in Table 3, Section 2.4). Thus, the competition of oxalate with target pollutants for $\mathrm{OH}^{\bullet}$ is minimized. The lower scavenging effect of this ligand towards $\mathrm{OH}^{\bullet}$ is especially interesting for the remediation of recalcitrant organic contaminants (with relatively low pollutants-OH${ }^{\bullet}$ rate constants). Otherwise, the low stability constant of Fe-OA (Table 2, Section 2.3) highlights the need to use a high concentration of this ligand to chelate the iron. Furthermore, similarly to citrate ligand, the addition of OA might decrease the reaction $\mathrm{pH}$ due to the relatively low $p K a$ value of this compound (Table 2, Section 2.3).

\subsubsection{Aminopolycarboxylic Acids (APCAs)}

Ethylenediaminetetraacetic Acid (EDTA)

This hexa-dentate aminocarboxylate $\mathrm{CA}$ has two $\mathrm{N}$ and four $\mathrm{O}$ donors (Figure 1). This is one of the most popular APCAs and has been widely used as a chelating agent for soil remediation [80,81]. EDTA can strongly combine with $\mathrm{Fe}(\mathrm{II})$ or Fe(III) to form stable metal complex in solution $(\log \beta(\mathrm{Fe}(\mathrm{II}))=14.3 ; \log \beta(\mathrm{Fe}(\mathrm{III}))=25.1$ [82], Table 2, Section 2.3). Fe(III)-EDTA can be reduced to Fe(II)-EDTA by $\mathrm{O}_{2}{ }^{\bullet-}$ (Equation (40)). This radical is previously generated by a series of serial reactions (Equations (36)-(39)) initiated by the reaction between $\mathrm{Fe}(\mathrm{III})$-EDTA and the oxidant $\left(\mathrm{H}_{2} \mathrm{O}_{2}\right)$. Finally, $\mathrm{Fe}(\mathrm{II})-\mathrm{EDTA}$ reacts with $\mathrm{H}_{2} \mathrm{O}_{2}$ generating hydroxyl radicals (Equation (41)) [43,44].

$$
\begin{gathered}
\mathrm{Fe}(\mathrm{III}) \text {-EDTA }+\mathrm{H}_{2} \mathrm{O}_{2} \rightarrow \mathrm{Fe}(\mathrm{III}) \mathrm{OOH}^{-} \text {-EDTA }+\mathrm{H}^{+} \\
\mathrm{Fe}(\mathrm{III}) \mathrm{OOH}{ }^{-} \text {-EDTA }+\mathrm{H}_{2} \mathrm{O}_{2} \rightarrow \mathrm{FeO}(\mathrm{II}) \text {-EDTA }+\mathrm{HO}_{2}^{\bullet}+\mathrm{H}_{2} \mathrm{O} \\
\mathrm{FeO}(\mathrm{II}) \text {-EDTA }+\mathrm{H}_{2} \mathrm{O}_{2} \rightarrow \mathrm{Fe}(\mathrm{III}) \text {-EDTA }+\mathrm{HO}_{2}^{\bullet}+\mathrm{OH}^{-} \\
\mathrm{HO}_{2} \bullet \rightarrow \mathrm{H}^{+}+\mathrm{O}_{2}^{\bullet} \\
\mathrm{Fe}(\mathrm{III})-\mathrm{EDTA}+\mathrm{O}_{2}^{\bullet-} \rightarrow \mathrm{Fe}(\mathrm{II}) \text {-EDTA }+\mathrm{O}_{2} \\
\mathrm{Fe}(\mathrm{II}) \text {-EDTA }+\mathrm{H}_{2} \mathrm{O}_{2} \rightarrow \mathrm{Fe}(\mathrm{III}) \text {-EDTA }+\mathrm{OH}^{\bullet}+\mathrm{OH}^{-}
\end{gathered}
$$

This mechanism supported that the interaction of Fe-EDTA and $\mathrm{O}_{2}{ }^{--}$strongly influences $\mathrm{OH}^{\bullet}$ production. Consequently, the summarized complex reaction proposed in Equation (15)), where a direct reduction of $\mathrm{Fe}(\mathrm{III})-\mathrm{L}$ by $\mathrm{H}_{2} \mathrm{O}_{2}$ is assumed, is not applicable for EDTA-chelated systems.

Conflicting conclusions on the nature of ROS formed in the Fe/EDTA/ $\mathrm{H}_{2} \mathrm{O}_{2}$ system were reported in the literature. For example, some authors reported that $\mathrm{Fe}(\mathrm{IV})$ was the reactive intermediate produced at near-neutral $\mathrm{pH}$ [83], whereas others identified $\mathrm{OH}^{\bullet}$ as the primary intermediate [25].

Although several authors corroborated the significant effect of EDTA in the improvement of Fenton effectiveness at near neutral $\mathrm{pH}$ in soils [84-87], its use is being limited since it has been recently considered an emerging contaminant of concern due to its low biodegradability, its contribution improving heavy metal mobility/bioavailability, and persistence in the environment [73,88-90]. Therefore, there is a long term need to replace 
the conventional complexing agent EDTA with better compounds, which are not only more biodegradable, but also provide improved technical performance [91].

Nitrilotriacetic Acid (NTA)

The tetra-dentate aminocarboxylate chelating agent (NTA) is one of the environmentally friendly CAs used to replace EDTA [41]. However, although NTA is biodegradable, its usage is controversial because it is moderately toxic to humans and mammals [92].

When using a NTA:Fe ratio of $1: 1,95 \%$ of NTA was bound in the Fe(III)-NTA complex [26]. Motekaitis et al. (1994) indicated that Fe(III)-NTA predominates at $\mathrm{pH}$ below 3 [93], while the main species at $\mathrm{pH}$ around 8 was reported to be $\left[\mathrm{Fe}(\mathrm{OH})_{2} \mathrm{NTA}\right]^{2-}$. This complex activates $\mathrm{H}_{2} \mathrm{O}_{2}$ to produce $\mathrm{OH}^{\bullet}$, presenting a lower $\mathrm{OH}^{\bullet}$ scavenging effect than the other species of Fe(III)-NTA complexes [94]. The reaction sequence for NTA-modified Fenton is summarized in Equations (42)-(50) [26]. Moreover, other oxygen radical competitive reactions (radicals recombination, reaction of hydroxyl radicals with $\mathrm{H}_{2} \mathrm{O}_{2}$ and with $\mathrm{Fe}(\mathrm{II}), \mathrm{O}_{2}{ }^{\bullet-}$ scavenger ability, etc.) corresponding to the previously reported for the homogenous Fenton (Equations (4)-(11)) should also be considered. Zhang et al. suggested that $\mathrm{Fe}(\mathrm{II})-\mathrm{NTA}$ is instantaneously oxidized to Fe(III)-NTA at the beginning of the reaction (Equation (42)), and after that, $\mathrm{OH}^{\bullet}$ is generated by using $\mathrm{O}_{2}{ }^{\bullet-}$ as an intermediate (Equation (46)) and not directly through the reaction of $\mathrm{Fe}(\mathrm{III})-\mathrm{NTA}$ and $\mathrm{H}_{2} \mathrm{O}_{2}$ (Equation (43)) [26]. In this way, as for the EDTA ligand, it was suggested that $\mathrm{H}_{2} \mathrm{O}_{2}$ was unlikely to reduce complexed iron [43], and the reduction of $\mathrm{Fe}(\mathrm{III})-\mathrm{L}$ was superoxide-dependent not $\mathrm{H}_{2} \mathrm{O}_{2}$ dependent. However, no $\mathrm{Fe}(\mathrm{II})$ was detected in the $\mathrm{Fe}(\mathrm{III}) / \mathrm{NTA} / \mathrm{H}_{2} \mathrm{O}_{2}$ modified Fenton system [26,43], and this could be attributed to three reasons: (1) too low reactivity of $\mathrm{O}_{2}{ }^{\bullet-}$ in the buffer solution, (2) short life-time of $\mathrm{O}_{2}{ }^{\bullet-}$ and (3) Fe(II)-NTA was generated by the Equation (46), but it was instantaneously oxidized to Fe(III)-NTA (Equation (42)) [26].

$$
\begin{gathered}
\mathrm{Fe}(\mathrm{II})-\mathrm{NTA}+\mathrm{H}_{2} \mathrm{O}_{2} \rightarrow \mathrm{Fe}(\mathrm{III})-\mathrm{NTA}+\mathrm{OH}^{\bullet}+\mathrm{OH}^{-} \\
\mathrm{Fe}(\mathrm{III})-\mathrm{NTA}+\mathrm{H}_{2} \mathrm{O}_{2} \rightarrow \mathrm{Fe}(\mathrm{III}) \mathrm{OOH}^{-}-\mathrm{NTA}+\mathrm{H}^{+} \\
\mathrm{Fe}(\mathrm{III}) \mathrm{OOH}{ }^{-}-\mathrm{NTA}+\mathrm{H}_{2} \mathrm{O}_{2} \rightarrow \mathrm{FeO}(\mathrm{II})-\mathrm{NTA}+\mathrm{HO}_{2}{ }^{\bullet}+\mathrm{H}_{2} \mathrm{O} \\
\mathrm{FeO}(\mathrm{II})-\mathrm{NTA}+\mathrm{H}_{2} \mathrm{O}_{2} \rightarrow \mathrm{Fe}(\mathrm{III})-\mathrm{NTA}+\mathrm{HO}_{2}{ }^{\bullet}+\mathrm{OH}^{-} \\
\mathrm{Fe}(\mathrm{III})-\mathrm{NTA}+\mathrm{HO}_{2}{ }^{\bullet} / \mathrm{O}_{2}{ }^{-}-\mathrm{Fe}(\mathrm{II})-\mathrm{NTA}+\mathrm{O}_{2} \\
\mathrm{Fe}(\mathrm{II})-\mathrm{NTA}+\mathrm{HO}_{2}{ }^{\bullet} / \mathrm{O}_{2}^{\bullet-} \rightarrow \mathrm{Fe}(\mathrm{III})-\mathrm{NTA}+\mathrm{O}_{2} \\
\mathrm{Fe}(\mathrm{II})-\mathrm{NTA}+\mathrm{OH}^{\bullet} \rightarrow \mathrm{Fe}(\mathrm{III})-\mathrm{NTA}+\mathrm{OH}^{-} \\
\mathrm{Fe}(\mathrm{III})-\mathrm{NTA}+\mathrm{OH}^{\bullet} \rightarrow \text { oxidized products } \\
\mathrm{NTA}+\mathrm{OH}^{\bullet} \rightarrow \text { oxidized products }
\end{gathered}
$$

Values reported in the literature for the rate constant between Fe(III)-NTA and $\mathrm{OH}^{\bullet}$ are in the range 1.6-4.8 $\times 10^{8} \mathrm{M}^{-1} \mathrm{~s}^{-1}[26,95]$ (Table 3, Section 2.4). In addition, significant scavenging of the hydroxyl radicals generated is expected by NTA due to the high rate constant between this $\mathrm{CA}$ and $\mathrm{OH}^{\bullet}$, especially significant at high $\mathrm{pH}$ values [95], as seen in Table 3.

Ethylenediaminedisuccinate (EDDS)

EDDS has recently emerged as an alternative chelating agent, this compound presenting properties similar to those of EDTA and readily biodegradable nature $[47,88,91,96]$. EDDS is a hexa-dentate aminocarboxylate soluble in water in any ratio [91].

The formation of different Fe-EDDS complexes as a function of $\mathrm{pH}$ has been reported elsewhere [97]. These authors stated that Fe(III)-EDDS ${ }^{-}$(with $\log \beta=20.6$ ) is predominant at acid $\mathrm{pHs}(\mathrm{pH} \leq 7)$ and hydrolyzed complex species $\left(\mathrm{Fe}(\mathrm{OH})\right.$-EDDS ${ }^{2-}$ and $\mathrm{Fe}(\mathrm{OH})_{2-}$ EDDS $^{3-}$ with $\log \beta=7.9$ and 9.9, respectively) at higher $\mathrm{pH}$ values. It has been reported that the suitable $\mathrm{pH}$ range for EDDS is from 3 to 9 [47]. The Fe(III)-EDDS complex has 
shown to be unstable at $\mathrm{pH}>8$, suggesting that the addition of EDDS does not significantly shift the precipitation of $\mathrm{Fe}(\mathrm{III})$ as iron hydroxide $\left(\mathrm{Fe}(\mathrm{OH})_{3}\right)$ under these conditions [32]. As mentioned above, apart from $\mathrm{pH}$, the $\mathrm{CA}$ :Fe molar ratio greatly affects the efficiency of the process. In this way, $\mathrm{Fe}(\mathrm{II})$-EDDS complex showed low ability to activate the oxidant at EDDS:Fe ratios higher than 1:1, due to the fact that the complete coordination of $\mathrm{Fe}(\mathrm{II})$ with an excess of EDDS forms a bulky hexacoordinated complex which hinders the attachment of $\mathrm{Fe}(\mathrm{II})$ by the oxidant [98]. The main reactions involved in the EDDS-MF process are summarized as follows (Equations (51)-(55) [46]):

$$
\begin{aligned}
& \mathrm{Fe}(\mathrm{II})-\mathrm{EDDS}+\mathrm{H}_{2} \mathrm{O}_{2} \rightarrow \mathrm{Fe}(\mathrm{III})-\mathrm{EDDS}+\mathrm{OH}^{\bullet}+\mathrm{OH}^{-} \\
& \mathrm{Fe}(\mathrm{III})-\mathrm{EDDS}+\mathrm{H}_{2} \mathrm{O}_{2} \rightarrow \mathrm{Fe}(\mathrm{II}) \text {-EDDS }+\mathrm{HO}_{2}{ }^{\bullet} / \mathrm{O}_{2}{ }^{\bullet-}+\mathrm{H}^{+} \\
& \mathrm{Fe}(\mathrm{II})-\mathrm{EDDS} / \mathrm{Fe}(\mathrm{III})-\mathrm{EDDS}+\mathrm{OH}^{\bullet} \rightarrow \text { oxidized products } \\
& \mathrm{Fe}(\mathrm{II}) \text {-EDDS }+\mathrm{HO}_{2} \bullet / \mathrm{O}_{2}{ }^{\bullet-} \rightarrow \mathrm{Fe}(\mathrm{III}) \text {-EDDS }+\mathrm{H}_{2} \mathrm{O}_{2} \\
& \mathrm{Fe}(\mathrm{III}) \text {-EDDS }+\mathrm{HO}_{2}{ }^{\bullet} / \mathrm{O}_{2}{ }^{\bullet-} \rightarrow \mathrm{Fe}(\mathrm{II}) \text {-EDDS }+\mathrm{O}_{2}
\end{aligned}
$$

The generation of $\mathrm{Fe}(\mathrm{II})$-EDDS from Fe(III)-EDDS reduction is the rate-limiting step, and any factor that can raise the corresponding rate constant (Equation (52)) would probably accelerate the formation rate of $\mathrm{OH}^{\bullet}$ (Equation (51)). Huang et al. suggested that bisphenol A degradation was mainly attributed to the action of $\mathrm{OH}^{\bullet}$ rather than $\mathrm{HO}_{2}{ }^{\bullet} / \mathrm{O}_{2}{ }^{\bullet-}$ at $\mathrm{pH}=6.2$ [47]. However, it was determined that the formation of hydroxyl radicals strongly depends on the presence of $\mathrm{O}_{2}{ }^{\bullet-}$ (Equation (55)). Indeed, $20 \%$ of $\mathrm{OH}^{\bullet}$ generated comes from the classical Fenton reactions (Equations (51) and (52)), without the need for superoxide radical, whereas the other $80 \%$ of $\mathrm{OH}^{\bullet}$ comes from the reduction of $\mathrm{Fe}(\mathrm{III})$-EDDS with superoxide radical anions (Equation (55)) (Figure 4, adapted from Huang et al. [47]).

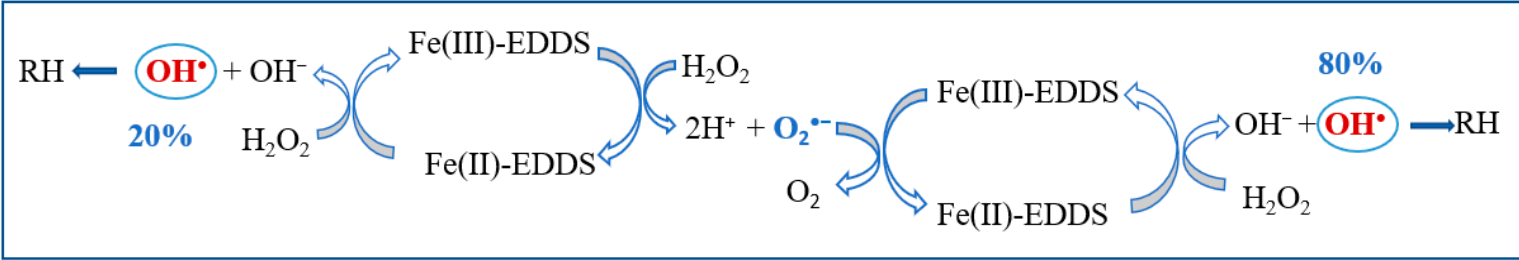

Figure 4. Simplified mechanism of organic pollutant degradation $(\mathrm{RH})$ in the $\mathrm{Fe} / \mathrm{EDDS} / \mathrm{H}_{2} \mathrm{O}_{2}$ system at $\mathrm{pH}=6.2$. Adapted from Huang et al. [47].

Since EDDS promotes the generation of superoxide radicals, the use of this new chelating agent in groundwater and soil remediation could be very effective [47]. Nevertheless, the application of this CA should be limited by the fast reaction between EDDS and $\mathrm{OH}^{\bullet}[46]$, (Table 3, Section 2.4).

\section{Ethylenediamine-N, $\mathrm{N}^{\prime}$-bis(2-hydroxyphenyl)acetic Acid (EDDHA)}

EDDHA is a biodegradable ligand with two phenolic groups substituting the carboxylates of EDTA (Figure 1), which highly increase its stability (Table 2, Section 2.3). Ma et al. proposed the oxidation mechanism of this CA based on a catalytic cycle (Figure 5, adapted from Ma et al. [56]), where the main reactions of the MF process in the presence of this CA are detailed. As can be seen, both $\mathrm{OH}^{\bullet}$ and $\mathrm{O}_{2}{ }^{\bullet-}$ radicals are of equal importance (50\% each one) in the degradation of PCBs in the $\mathrm{Fe}(\mathrm{II}) / \mathrm{EDDHA} / \mathrm{H}_{2} \mathrm{O}_{2}$ system [56]. NahimGranados et al. stated that the presence of light in the Fe/EDDHA $/ \mathrm{H}_{2} \mathrm{O}_{2}$ system favors the reduction of $\mathrm{Fe}(\mathrm{III})$ to $\mathrm{Fe}(\mathrm{II})$ [99]. 


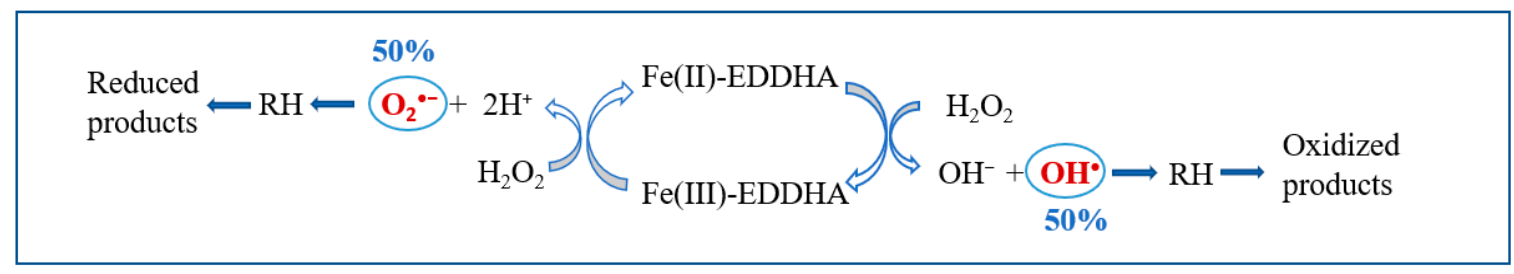

Figure 5. Simplified mechanism of organic pollutant degradation $(\mathrm{RH})$ in the Fe/EDDHA $/ \mathrm{H}_{2} \mathrm{O}_{2}$ system. Adapted from Ma et al. [56].

\subsubsection{Humic Substances (HS) and Soil Organic Matter (SOM)}

Humic substances are the major constituents of the organic matter of soils and sediments. HS are naturally occurring organic compounds that arise from the decomposition and transformation of plant, animal, and microbial residues [100]. They are organic substances of high molecular weight and refractory to biodegradation. Humic substances are classified into humic and fulvic acids (HA and FA, respectively). Both are ubiquitous without potential toxicity. Thus, these compounds can be considered "greener" amendments for the MF process [101].

Humic acids are composed of molecules rich in acidic functional groups, mainly carboxyl and phenolic groups, and hydrophobic moieties such as alkyl chains and aromatic cores. These substances have been used in literature as an amendment to improve the abatement of organic compounds by the Fenton reaction, especially in aqueous phase [75,102-104], although the reaction mechanism is not completely understood.

The applicability of HA as chelating agent in soil remediation greatly enhances the oxidation rate of organic compounds at neutral $\mathrm{pH}$, the costs increase associated being negligible [75]. Georgi et al. suggested that $\mathrm{OH}^{\bullet}$ are the main reactive species in the HA-modified Fenton system [75], whereas Yang et al. reported that superoxide was also a dominant ROS [105]. In the same way, the addition of FA as CA increases the rate constant of Fenton's reaction as a result of the formation of Fe(II)-fulvate at near circumneutral $\mathrm{pH}$ [106]. Moreover, it has been demonstrated that HAs act as sorbents for hydrophobic organic compounds from soil [101].

Recently, the research interest is focused on the possibility of extract these substances from organic wastes. In this way, Zingaretti et al. tested the use of HAs extracted from compost in a MF process, and the obtained results were equivalent to those achieved applying commercial HAs or traditional amendments $\left(\mathrm{KH}_{2} \mathrm{PO}_{4}\right.$ and EDTA) [101]. HAs extracted from compost were able to chelate $0.04 \mathrm{mg}^{\text {iron } \mathrm{mg}_{\mathrm{HA}}}{ }^{-1}$ and increased the lifetime of the oxidant similarly to the traditional stabilizers used. Moreover, the extracted humic acids allowed to obtain a normalized radius of influence higher than those observed using EDTA. Therefore, it was demonstrated that extracted HAs could be simultaneously used as $\mathrm{H}_{2} \mathrm{O}_{2}$ stabilizer and chelating agent [101]. The use of these natural substances (HAs extracted from compost) was also evaluated for the remediation of diesel-contaminated soil [107]. The addition of HAs $\left(10 \mathrm{~g} \mathrm{~L}^{-1}\right)$ showed a beneficial effect on the hydrogen peroxide stability, especially when combined with $\mathrm{KH}_{2} \mathrm{PO}_{4}$. In the same line, Zingaretti et al. have also explored the possibility to extract HAs from the bio-stabilized waste produced from a Mechanical Biological treatment plant [108]. The HAs obtained showed high functional group contents and aromaticity, equivalent to the characteristics of commercial HAs, allowing to consider these substances for different applications such as the MF process [108].

SOM, the organic fraction of the soil, which includes humic substances, can also develop an important role as $\mathrm{CA}$. Xu et al. reported that SOM can combine with iron ions to form Fe-SOM, catalyzing the decomposition of $\mathrm{H}_{2} \mathrm{O}_{2}$ to produce $\mathrm{OH}^{\bullet}$ in the solid phase, which directly oxidizes the pollutant (crude oil) [109], as described in Figure 6a (adapted from $\mathrm{Xu}$ et al. [109]). This contrasted with the $\mathrm{OH}^{\bullet}$ production and the oil degradation in the aqueous phase in the absence of Fe-SOM (Figure $6 \mathrm{~b}$ ). 


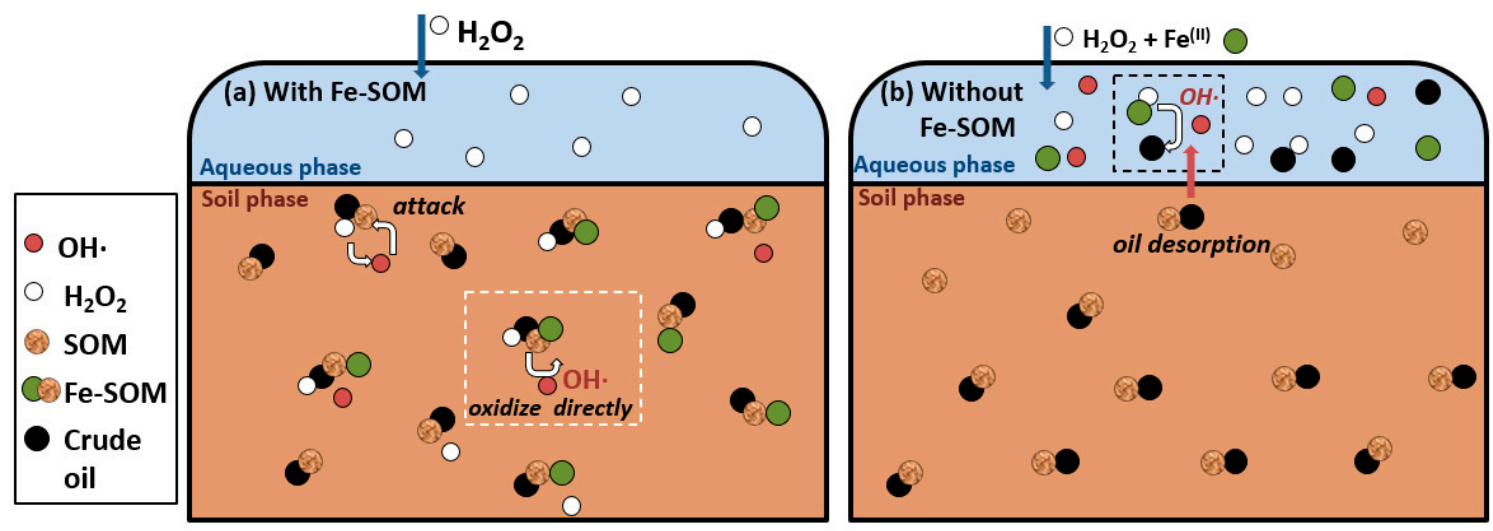

Figure 6. Schematic representation of different oxidation mechanism in soil for the degradation of crude oil; (a) with Fe-SOM and (b) without Fe-SOM. Adapted from Xu et al. [109].

\subsection{Chelating Agents' Properties}

For each CA considered in the present review (those most commonly used for soil remediation in the MF process), an overview on the most relevant properties, such as the type of ligand (inorganic/organic), the cost, biodegradability, and toxicity, has been performed and the information found in the literature has been summarized in Table 1. As previously stated, the presence of some CAs increases the stability of hydrogen peroxide. This important issue has also been considered in Table 1.

Table 1. Summary of the main characteristics of the chelating agents applied in Fenton process.

\begin{tabular}{|c|c|c|c|c|c|}
\hline Ligand & Type & Biodegradability & Toxicity & Cost & Stabilizing Effect \\
\hline PPP & Inorganic & Biodegradable & Non-toxic & $597 \$ \mathrm{t}^{-1}(\mathrm{SP})[56]$ & Yes $[54,56,59]$ \\
\hline Citrate & Organic & Biodegradable [35] & Non-toxic & $450-590 \$ \mathrm{t}^{-1}(\mathrm{SC})$ & Yes $[35,72]$ \\
\hline Oxalate & Organic & Biodegradable & Non-toxic & $450-510 \$ t^{-1}(\mathrm{OA})$ & Yes (moderate) [55] \\
\hline EDTA & Organic & Non-biodegradable [110] & Toxic [110] & $4 € \mathrm{~L}^{-1}$ (solution at $40 \%$ ) [86] & No [35] \\
\hline NTA & Organic & Biodegradable [92] & Moderately toxic [92] & n.f. & n.f. \\
\hline EDDS & Organic & Biodegradable $[91,111]$ & Non-toxic [110] & n.f. & Yes $[72,88]$ \\
\hline EDDHA & Organic & Biodegradable [111] & Non-toxic [111] & n.f. & Yes [56] \\
\hline HA & Organic & Biodegradable [101] & Non-toxic [75] & $1000 € \mathrm{t}^{-1}$ (sodium humate) & Yes [101,107] \\
\hline
\end{tabular}

Other aspects, such as the $p K a$ values and the stability constants of the complexes (Fe(II)-L and Fe(III)-L) formed, have been summarized in Table 2. As previously stated, the stability constant indicated the tendency of forming the Fe-L complex. From the results summarized in Table 2, citrate and oxalate ligands present relatively low stability constant, and thus, higher CA:Fe ratios would be needed when using these CAs compared to others having higher stability constants, such as PPP, EDDHA or EDTA. On the other hand, as previously mentioned, it can be observed that those CAs presenting lower stability constants of Fe-L complexes (citrate and oxalate) have lower $p K a$ values. It should be considered that the addition of CAs with low $p K a$ values would decrease the $\mathrm{pH}$ of the MF system. In this way, the possible ecological impact on the soil should be considered before selecting these CAs. 
Table 2. pKa values of CAs and stability constants ( $\log \beta)$ of the Fe(II)/(III)-L formation.

\begin{tabular}{|c|c|c|c|c|c|c|c|c|c|}
\hline & PPP & $\begin{array}{l}\text { Citrate } \\
\text { (CitrA) }\end{array}$ & $\begin{array}{c}\text { Citrate } \\
\text { (SC) }\end{array}$ & $\begin{array}{c}\text { Oxalate } \\
\text { (OA) }\end{array}$ & EDTA & NTA & EDDS & EDDHA & HA \\
\hline pKa: pKa & 0.8 [53] & \multicolumn{2}{|c|}{3.0 [112] } & 1.2 [113] & 2.0 [114] & 1.8 [95] & 2.4 [114] & 6.3 [115] & $4.1-8.8$ \\
\hline $\mathrm{pKa}_{2}$ & 2.3 [53] & \multicolumn{2}{|c|}{4.6 [112] } & 4.2 [113] & 3.0 [114] & $2.3[95]$ & 3.9 [114] & 8.6 [115] & [116] \\
\hline $\mathrm{pKa}_{3}$ & 6.7 [53] & \multicolumn{2}{|c|}{5.8 [112] } & & 6.4 [114] & 9.4 [95] & 6.8 [114] & $10.2[115]$ & \\
\hline $\mathrm{pKa}_{4}$ & 9.5 [53] & & & & 10.4 [114] & & 9.8 [114] & 11.7 [115] & \\
\hline $\begin{array}{l}\log \beta \text { of } \\
\text { Fe(II)-L }\end{array}$ & $\begin{array}{c}18.4 \\
{[56,117]}\end{array}$ & 3.2 [118] & $\begin{array}{c}15.5 \\
{[55,65]}\end{array}$ & $4.5[55]$ & $\begin{array}{c}14.3 \\
{[55,82]}\end{array}$ & 8.1 [82] & n.f. & 14.3 [119] & 1.3 [116] \\
\hline $\begin{array}{l}\log \beta \text { of } \\
\operatorname{Fe}(\text { III)-L }\end{array}$ & 39.2 [55] & $\begin{array}{l}11.5 \\
11.9\end{array}$ & $25[55,65]$ & 7.5 [55] & $\begin{array}{c}25.1 \\
{[55,82]}\end{array}$ & $\begin{array}{c}15.9 \\
{[82,92]}\end{array}$ & $\begin{array}{c}20.6[97] \\
22.0[121]\end{array}$ & 33.9 [119] & 2.5 [116] \\
\hline
\end{tabular}

n.f. $=$ not found. $\mathrm{pKa}_{1-4}$ are the acid ionization constant values for a poliprotonic acid, which corresponds to Equations (25)-(28), Log $\beta$ of $\mathrm{Fe}(\mathrm{II})-\mathrm{L}$ correspond to Equation (12) and $\log \beta$ of $\mathrm{Fe}(\mathrm{III})-\mathrm{L}$, to Equation (13).

\subsection{Kinetic Constants of Chelate-Modified Fenton Process}

The kinetic constants found in the literature for the main CAs studied in the MF process (Equations (14), (18), (23), and (24)) and the corresponding to the homogeneous Fenton reaction (in the absence of CA), have been summarized in Table 3. In addition, the main reactive oxygen species (ROS) involved in these reactions have also been included.

Regarding radical species, it has been reported that under acidic conditions $\mathrm{OH}^{\bullet}$ was the main oxidizing intermediate generated in the Fenton system. However, at near-neutral $\mathrm{pH}$, the reactive intermediate shifted to Fe(IV) compounds [122]. However, contradictory conclusions on the nature of reactive intermediate formed in MF systems have been obtained in the literature [123]. To clarify this aspect, a recent study carried out by Wang et al. supported that $\mathrm{Fe}(\mathrm{II})-\mathrm{L}$ ( $\mathrm{L}=\mathrm{OA}$, CitrA, NTA, EDTA, PPP, and tetrapolyphosphate (TPP)) tended to catalyze $\mathrm{H}_{2} \mathrm{O}_{2}$ to generate $\mathrm{OH}^{\bullet}$ rather than $\mathrm{Fe}(\mathrm{IV})$ [123]. Moreover, some authors have recently clarified the role of the $\mathrm{O}_{2}{ }^{-}-$in the EDDS-MF [47] and EDDHA-MF systems [56].

A major effort has been made to find as much data as possible with respect to the kinetic rate constants of the reaction mechanism of $\mathrm{Fe}(\mathrm{II})-\mathrm{L}$ oxidation (and potentially $\mathrm{Fe}(\mathrm{III})-\mathrm{L}$ reduction) in the presence of different $\mathrm{CAs}$, and the negative hydroxyl radical (from $\mathrm{H}_{2} \mathrm{O}_{2}$ decomposition) scavenger effect of the ligand. However, no values have been found for many of the cases (mainly those related to EDDS, EDDHA and HA ligands), highlighting the need for further research in this field. It has also been difficult to obtain a reliable literature estimate for the reduction rate constant of Fe(III)-L to Fe(II)-L by superoxide radicals (Equation (18)).

As shown in Table 3, the addition of CAs significantly increases the reaction rate constant of Equation (14), compared to the corresponding traditional Fenton Equation (1). As previously reported, the higher stability constant of $\mathrm{Fe}(\mathrm{III})-\mathrm{L}$ indicates a higher reaction rate of Fe(II)-L with oxidant [41,124].

Concerning the scavenger effect of the CAs under study, oxalate has the lowest reaction rate constants corresponding to Equations (23) and (24), respectively. This would justify its

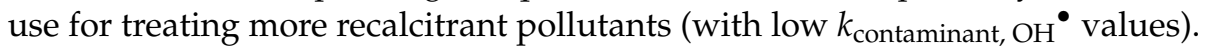


Table 3. Kinetic constants for the Fenton process in the presence of different CAs.

\begin{tabular}{|c|c|c|c|c|c|}
\hline Ligand (L) & $\begin{array}{l}\text { ROS Involved in } \\
\text { Pollutant Degradation }\end{array}$ & $\begin{array}{c}k_{\mathrm{Fe}(\mathrm{II})-\mathrm{L}, \mathrm{H}_{2} \mathrm{O}_{2}} \\
\left(\mathbf{M}^{-1} \mathbf{s}^{-1}\right) \\
\text { Equation (14) }\end{array}$ & $\begin{array}{l}k_{\mathrm{Fe}(\mathrm{III})-\mathrm{L}, \mathrm{O}_{2}}{ }^{\bullet-} \\
\left(\mathbf{M}^{-1} \mathbf{s}^{-1}\right) \\
\text { Equation (18) }\end{array}$ & $\begin{array}{c}k_{\mathrm{Fe}(\mathrm{II})-\mathrm{L} / \mathrm{Fe}(\mathrm{III})-\mathrm{L}, \mathrm{OH}} \\
\left(\mathbf{M}^{-1} \mathbf{s}^{-1}\right) \\
\text { Equation }(23)\end{array}$ & $\begin{array}{c}k_{\mathrm{L}, \mathrm{OH}} \\
\left(\mathbf{M}^{-1} \mathbf{s}^{-1}\right) \\
\text { Equation }(24)\end{array}$ \\
\hline- & $\begin{array}{c}\mathrm{OH}^{\bullet}(\text { acidic } \mathrm{pH} \text { ) or } \\
\mathrm{Fe}(\mathrm{IV})(\text { neutral } \mathrm{pH})[49]\end{array}$ & $\begin{array}{l}\text { Equation (1): } \\
40-80[21,24]\end{array}$ & n.f. & $\begin{array}{l}\text { Equation (4): Fe(II): } \\
2.5-5 \times 10^{8}[21,24]\end{array}$ & - \\
\hline PPP & $\mathrm{OH}^{\bullet}[123]$ & $1 \times 10^{5}[53,69,78]$ & n.f. & n.f. & $\begin{array}{l}2.2 \times 10^{5}[125] \\
9 \times 10^{5}[126]\end{array}$ \\
\hline Citrate & $\mathrm{OH}^{\bullet}[64,123]$ & $\begin{array}{c}3.6 \times 10^{3}[64] \\
4 \times 10^{3}[25] \\
4.9 \times 10^{3}[69]\end{array}$ & 800 [25] & $\begin{array}{c}\text { Fe(II)-L: } 1.2 \times 10^{8}[25] \\
\text { Fe(III)-L: } 1.2 \times 10^{8} *[70]\end{array}$ & $\begin{array}{c}5 \times 10^{7}[126,127] \\
1.2 \times 10^{8}(\mathrm{pH}=3) \\
2.4 \times 10^{8}(\mathrm{pH}=6) \\
3.2 \times 10^{8}(\mathrm{pH}=6.6)[70]\end{array}$ \\
\hline Oxalate & $\mathrm{OH}^{\bullet}[123]$ & $3.1 \times 10^{4}[77]$ & $<1.0 \times 10^{6}[128]$ & $\begin{array}{c}\text { Fe(II)-L: n.f. } \\
\text { Fe(III)-L: } 1 \times 10^{6}[126]\end{array}$ & $\begin{array}{c}1.4 \times 10^{6}[79] \\
7.7 \times 10^{6}[128] \\
1 \times 10^{7}[70]\end{array}$ \\
\hline EDTA & $\mathrm{OH}^{\bullet}[123]$ & $3.2 \times 10^{3}[25]$ & $\begin{array}{c}6 \times 10^{4}[25] \\
1.2 \times 10^{6}(\mathrm{pH}=7.3)[44]\end{array}$ & $\begin{array}{c}\text { Fe(II)-L: } 5 \times 10^{9}[126] \\
\text { Fe(III)-L: } 7.0 \times 10^{8}- \\
1.6 \times 10^{9}[126]\end{array}$ & $\begin{array}{c}4 \times 10^{8}(\mathrm{pH}=4)[79] \\
2 \times 10^{9}(\mathrm{pH}=9) \\
{[79,129]}\end{array}$ \\
\hline NTA & $\mathrm{OH}^{\bullet}[26,123]$ & $\begin{array}{c}9.7 \times 10^{3}- \\
1.8 \times 10^{4}[95]\end{array}$ & n.f. & $\begin{array}{c}\text { Fe(II)-L: } 2.3-5 \times 10^{9}[126] \\
\text { Fe(III)-L: } 4.8 \times 10^{8}[26] \\
1.6 \times 10^{8}[95,126]\end{array}$ & $\begin{array}{c}5.5 \times 10^{8}(\mathrm{pH}=6) \\
2.5 \times 10^{9}(\mathrm{pH}=9) \\
4.2 \times 10^{9}(\mathrm{pH}=10)[95]\end{array}$ \\
\hline EDDS & $\begin{array}{c}\mathrm{OH}^{\bullet}(80 \%) \text { and } \mathrm{O}_{2} \bullet- \\
(20 \%)[47]\end{array}$ & n.f. & n.f. & $\begin{array}{c}\mathrm{Fe}(\mathrm{II}) /(\mathrm{III})-\mathrm{L}: \\
2.0-5.2 \times 10^{8}[47]\end{array}$ & $2.5 \times 10^{9}[46]$ \\
\hline EDDHA & $\begin{array}{l}\mathrm{OH}^{\bullet}(50 \%) \text { and } \mathrm{O}_{2} \bullet- \\
(50 \%)[56]\end{array}$ & n.f. & n.f. & n.f. & n.f. \\
\hline HA & $\begin{array}{l}\mathrm{OH}^{\bullet} \cdot[130] \text { or } \\
\mathrm{O}_{2} \cdot{ }^{\bullet}[105]\end{array}$ & n.f. & n.f. & n.f. & $\begin{array}{c}1.4 \times 10^{4} \mathrm{LmgC}^{-1} \mathrm{~s}^{-1} \\
{[130]}\end{array}$ \\
\hline
\end{tabular}

n.f. $=$ not found. ${ }^{*}$ These authors supposed that $k_{\mathrm{Fe}(\mathrm{III}) \mathrm{L}, \mathrm{OH}}{ }^{\bullet}$ was like $k_{\mathrm{L}, \mathrm{OH}} \bullet$

\section{Application of Chelating Agents in Soil Remediation by Modified Fenton}

\subsection{Factors Affecting Contaminant Removal}

When applying chelate-modified Fenton technology for the remediation of contaminated soils, some common factors can affect the effectiveness of the process. The most important ones are detailed below.

\subsubsection{Contaminant Accessibility}

An important aspect in the remediation of contaminated soils derives from the accessibility of the contaminants. Pollution ageing leads to the migration of contaminant from easily accessible to difficult sites, becoming sequestrated in the soil matrix [35], which reduces the chemical remediation efficiency of hydrophobic organic pollutants [131]. Consequently, several authors have reported that pollutant removal by the Fenton process decreases with contamination ageing [85]. For example, Jorfi et al. observed that working under the same experimental conditions, removing of pyrene in spiked contaminated soil was $91 \%$ compared to the $43 \%$ obtained in a real soil sample [85]. Thus, one of the most limiting factors in soil remediation is the low availability of contaminants, partly sequestrated in the aged soils. Although some authors proposed that Fenton reaction can improve the remediation process due to the desorption of hydrophobic contaminants $[85,132]$, a refractory fraction of the contaminant remained in the solid phase after the treatment [133]. In this sense, chelating agents can also enhance the desorption of the contaminants $[35,134,135]$, and therefore favor the accessibility of the contaminant towards the oxidant.

\subsubsection{Soil Matrix: Organic Matter, Carbonates and Metals Content}

Another limiting factor in the remediation of soils when using CAs is the negative effect of the soil matrix. It has been reported that the soil type determines the concentration of soluble Fe(III) in soil slurry systems, probably through hydrolysis and adsorption [59]. Meanwhile, the stability of $\mathrm{H}_{2} \mathrm{O}_{2}$ seems to relate not only to the stability of $\mathrm{Fe}(\mathrm{III})$ complexes 
but also to the properties of the soil system [55]. Bicarbonate and carbonate are present in high concentrations in calcareous soils. Their presence has been reported to cause competitive reactions with hydroxyl radicals, inhibiting the degradation of the contaminant by the $\mathrm{OH}^{\bullet}$ (Equations (56) and (57), with the corresponding $k_{56}$ and $k_{57}$ ) [136], generated in the MF process.

$$
\begin{gathered}
\mathrm{HCO}_{3}{ }^{-}+\mathrm{OH}^{\bullet} \rightarrow \mathrm{CO}_{3}^{\bullet-}+\mathrm{H}_{2} \mathrm{O} \\
k_{56}=8.5 \times 10^{6} \mathrm{M}^{-1} \mathrm{~s}^{-1} \\
\mathrm{CO}_{3}{ }^{2-}+\mathrm{OH}^{\bullet} \rightarrow \mathrm{CO}_{3}^{\bullet-}+\mathrm{OH}^{-} \\
k_{57}=3.9 \times 10^{8} \mathrm{M}^{-1} \mathrm{~s}^{-1}
\end{gathered}
$$

In this way, Lemaire et al. reported that the degradation rate of PAH did not increase significantly with the addition of citric acid [137]. The high carbonate content of the soil (35 $\mathrm{g} \mathrm{kg}^{-1}$ ) led to hydrogenocarbonate and carbonate ions transfer to the liquid phase, increasing hydroxyl radical scavenging (Equations (56) and (57)). The high content of soil organic matter (SOM) also increases oxidant consumption $[35,59,88]$. Moreover, when the concentration of SOM is high, part of the hydroxyl radicals generated is consumed by side reactions, decreasing the pollutants' degradation [137]. CAs might alter the association between SOM and the inorganic matrix or affect the SOM structure itself [138], and this should also be studied before selecting a chelating agent. As stated in Section 2.2.3, in the case of soil with high content of SOM, it could combine with iron ions to form Fe-SOM and catalyze the decomposition of $\mathrm{H}_{2} \mathrm{O}_{2}$ to produce $\mathrm{OH}^{\bullet}$, avoiding the use of other chelating agents [81,109].

On the other hand, the intrinsic minerals in soil can be positive for soil remediation by MF. These minerals can serve as catalysts for the oxidant, increasing the removal of the pollutants. For all those mentioned above, the specific characteristics of the soil should be considered to properly select the CA for MF process. In this way, the reaction mechanisms previously reported and most of them obtained performing experiments in the aqueous phase will be more complex. Although the experiments to elucidate the reaction mechanisms and kinetics for constructing predictive models for soils have been carried out using correct chemical stoichiometry, the study of some important aspects is still missing in the literature. This is the case of separate measurements of adsorbed and dissolved chemicals (CAs and catalysts), determination of proper chemical stoichiometry depending on soil matrix, measurements of filled and empty adsorption sites, calculation of time-dependent kinetic rate coefficients for each reaction or process, etc.

\subsubsection{Soil Texture and Moisture}

Loose soil texture can help the mass transfer of reagents, while dense soil leads to large consumption of reagents [9]. In this way, the Fenton process is favored in soils containing higher surface area and high pore volumes due to enhanced accessibility [35]. Peluffo et al. explored the effect of moisture content in the presence of chemical oxidants [139]. These authors demonstrated that an increase in soil moisture (from $25 \%$ to $37 \%$ ) greatly increased the pollutant removal (phenanthrene) when a low oxidant dose was employed, whereas the results with a high oxidant dose were reversed. Moreover, the oxidant decomposition rate decreased at high moisture levels, possibly through diluting $\mathrm{H}_{2} \mathrm{O}_{2}$-activators within the soil. Thus, for oxidative treatments of contaminated soil, the application of low doses of oxidant at low soil-moisture levels seems to be the most effective option.

\subsubsection{Adsorption and Desorption of Chemicals onto the Soil}

The adsorption and desorption of chemicals (chelating agent and catalyst) onto the soil is a limiting factor that should be considered when applying MF process to remediate polluted soils. Some authors observed a significant dependence of the liquid/soil phase ratio $\left(\mathrm{V}_{\mathrm{L}} / \mathrm{W}\right)$ on the amount of adsorption of chemicals. Adsorption is often increased with decreasing the $\mathrm{V}_{\mathrm{L}} / \mathrm{W}$ ratios, being the recommended ratio from 2 to 4 [140]. However, the chemicals (CAs, catalyst, etc.) mobility through the soil and the optimum $V_{L} / W$ ratio 
can vary depending on the type of soil studied and its composition. For example, in the $\mathrm{Fe}(\mathrm{III})$ /EDDHA system, organic matter and iron oxides or hydroxides have been identified as the most reactive soil constituents and calcium carbonate and clay as the least reactive ones for Fe-EDDHA adsorption onto the soil [140]. Determining the amount of soluble $\mathrm{CA}$ and Fe-L in batch and columns is a useful tool to compare the reactivities of different CAs and establish the CAs long-lasting effect on the soil solution. In this way, although several investigations have been carried out to study the Fe-L retention by the soil when using different CAs (such as EDDHA, EDTA, diethylenetriaminepentaacetic acid (DTPA), etc.) [140-142], further research is needed concerning this aspect when applying CAs to enhance Fenton process in soil remediation. To the best of our knowledge, adsorption of CAs has been scarcely studied in the literature. Rosas et al. studied the adsorption of an organic CA (citrate) and diuron, which was much lower than that of the organic pollutant [143]. To further explore this aspect, futures investigations should include a detailed study of the interactions of the CA and Fe-L complexes with soil and soil constituents and its diminution from the solution related to possible degradation or adsorption mechanisms.

\subsection{Results of Modified Fenton Obtained according to the Contaminant Type}

The review of CAs application in the MF process will be carried out according to the main types of contaminants found in the literature for soil remediation. According to their characteristics, pollutants have been divided into the following groups: (i) BTEX and phenolic compounds, (ii) polycyclic aromatic hydrocarbons (PAHs), (iii) total petroleum hydrocarbons (TPHs), (iv) unsaturated chlorinated compounds and pesticides, and (v) saturated chlorinates compounds. The reaction rate of each contaminant with the generated

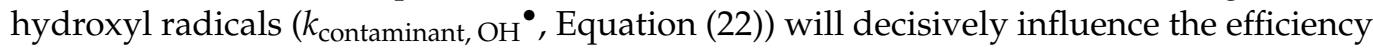
on its removal when applying the MF process. In this way, the $k_{\text {contaminant, }{ }^{\bullet}}{ }^{\bullet}$ values found in the literature have been summarized in Table 4. It should be noted that other reactive oxidants such as superoxide radical, hydroperoxyl radical, and $\mathrm{Fe}(\mathrm{IV})$ have not been included since $\mathrm{OH}^{\bullet}$ can be considered as the dominant ROS (Table 3). However, it is noteworthy that exploring the nature of the Fe(IV) species from the MF reactions (including issues on the distinguishment from $\mathrm{OH}^{\bullet}$ ) is a challenging task nowadays [144], and further research is needed to clarify the chemistry of $\mathrm{Fe}(\mathrm{IV})$. 
Table 4. Kinetic constants of different organic contaminants with hydroxyl radicals.

\begin{tabular}{|c|c|c|c|}
\hline Group & Contaminant & $\begin{array}{c}k_{\text {contaminant, } \mathrm{OH}^{\bullet}} \\
\left(\mathrm{M}^{-1} \mathbf{s}^{-1}\right),(\text { Equation (22)) }\end{array}$ & Ref. \\
\hline \multirow{6}{*}{$\begin{array}{l}\text { BTEX/phenolic } \\
\text { compounds }\end{array}$} & Benzene & $6.6 \times 10^{8}$ & [145] \\
\hline & Toluene & $3.4 \times 10^{9}$ & [145] \\
\hline & Ethylbenzene & $4.1 \times 10^{9}$ & [145] \\
\hline & Xylene & $9.5 \times 10^{9}$ & [145] \\
\hline & Phenol & $6.6 \times 10^{9}$ & [145] \\
\hline & Bisphenol-A & $9.8 \times 10^{9}$ & [146] \\
\hline \multirow{6}{*}{ PAHs } & Acenaphthene & $8.8 \times 10^{9}$ & [147] \\
\hline & Benzo[a]pyrene & $2.53 \times 10^{10}$ & [147] \\
\hline & Chrysene & $9.82 \times 10^{9}\left(20^{\circ} \mathrm{C}, \mathrm{pH}=7\right)$ & [147] \\
\hline & Fluorene & $2.8-9.9 \times 10^{9}$ & [147] \\
\hline & Naphthalene & $0.5-1.2 \times 10^{10}$ & [147] \\
\hline & Phenanthrene & $1.34 \times 10^{10}$ & [147] \\
\hline \multirow{10}{*}{$\begin{array}{l}\text { Unsaturated chlorinated } \\
\text { compounds and } \\
\text { pesticides }\end{array}$} & $\begin{array}{l}\text { Polychlorinated } \\
\text { biphenyls (PCBs) }\end{array}$ & $5 \times 10^{9}$ & [148] \\
\hline & Diuron & $4.8 \times 10^{9}$ & [126] \\
\hline & Trichloroethylene (TCE) & $3-4 \times 10^{9}$ & {$[126,147]$} \\
\hline & Tetrachloroethene (PCE) & $2.8 \times 10^{9}$ & [126] \\
\hline & Pentachlorophenol (PCP) & $4 \times 10^{9}$ & [147] \\
\hline & 1,1-dichloroethene & $6.8 \times 10^{9}$ & [126] \\
\hline & Vinyl chloride & $1.2 \times 10^{10}$ & [126] \\
\hline & $\begin{array}{l}\text { Atrazine, propazine, } \\
\text { and terbuthylazine }\end{array}$ & $2.2-3.5 \times 10^{9}$ & [130] \\
\hline & 1,2,3-trichlorobenzene & $6.1 \times 10^{9}$ & [147] \\
\hline & 1,4-dichlorobenzene & $5.4 \times 10^{9}$ & [147] \\
\hline \multirow{2}{*}{$\begin{array}{l}\text { Saturated chlorinated } \\
\text { compounds }\end{array}$} & $\begin{array}{c}\gamma \text {-hexachlorocyclohexane } \\
\text { (lindane) }\end{array}$ & $5.8 \times 10^{8}$ & [148] \\
\hline & Trichloromethane & $5.0 \times 10^{6}$ & [47] \\
\hline
\end{tabular}

\subsubsection{BTEX and Phenolic Compounds}

BTEX (benzene, toluene, ethylbenzene and xylenes) and phenolic compounds are organic compounds identified as hazardous chemicals due to adverse effects on human health at very low concentrations [149]. In addition, the high-water solubility and volatility of BTEX enable them to migrate in the subsurface and contaminate soils. In this way, a great effort has been made to remediate soils contaminated by these compounds [150]. However, the application of Fenton enhanced by the addition of chelating agents (MF process) for the remediation of soils polluted with BTEX and phenolic compounds has been poorly studied to date.

The limited number of works found in the literature concerning the remediation of this pollutants group by the MF process have been summarized in Table 5. This table contains information about the CAs tested, the oxidation process and the reagents molar ratios selected as the most convenient, the type of soil treated (spiked or real), the type of experiments (batch or column), the pollutant and its concentration in the contaminated soils, the liquid to soil mass ratio $\left(\mathrm{V}_{\mathrm{L}} / \mathrm{W}\right)$ and the system $\mathrm{pH}$, the reaction time and, finally, the main results obtained concerning the pollutants, hydrogen peroxide, and CA conversions. The same information (for the corresponding pollutants group) is collected in Tables 6-8. 
Table 5. Research studies for BTEX and phenolic compounds degradation in soils using MF process.

\begin{tabular}{|c|c|c|c|c|c|c|c|c|}
\hline Tested CA & $\begin{array}{c}\text { Treatment and Optimal } \\
\text { Reagents Dose } \\
\text { Concentration (mM) and } \\
\text { Molar ratio }\end{array}$ & $\begin{array}{l}\text { Pollutant cc. } \\
\text { (mg kg } \text { kg) }^{-1)}\end{array}$ & $\mathrm{pH}$ & $\begin{array}{c}\text { Soil Type/Reaction } \\
\text { System }\end{array}$ & $\mathrm{V}_{\mathrm{L}} / \mathrm{W}(\mathrm{mL} / \mathrm{g})$ & Reaction Time & Conversion (\%) & Ref \\
\hline $\begin{array}{l}\text { (a) } \mathrm{H}_{2} \mathrm{O}_{2} \text { Stabilizer: } \\
\text { DP } \\
\text { (b) Chelant: } \\
\text { EDTA, 1-AA } \\
\text { GA, CitrA, SC }, \text { SC } \\
\text { (c) Chelant: } \\
\text { EDTA, SC }\end{array}$ & $\begin{array}{l}\text { (a) Stabilization study }(\mathrm{DP}) \text { : } \\
{\left[\mathrm{H}_{2} \mathrm{O}_{2}\right]=290-580 \mathrm{mM} \text {, }} \\
{[\mathrm{DP}]=58-116 \mathrm{mM}} \\
\mathrm{Natural} \text { Fe species present in } \\
\text { the soil } \\
\mathrm{H}_{2} \mathrm{O}_{2}: \mathrm{DP}=5: 1 \\
\text { (b) Stabilization study }(6 \mathrm{CAs}) \text { : } \\
{\left[\mathrm{H}_{2} \mathrm{O}_{2}\right]=290 \mathrm{mM} \text {, }} \\
{[\mathrm{CA}]=50 \mathrm{mM}} \\
\mathrm{H}_{2} \mathrm{O}_{2}: \mathrm{CA}=5.8: 1 \\
\text { (c) Contaminant removal } \\
{\left[\mathrm{H}_{2} \mathrm{O}_{2}\right]=290 \mathrm{mM}} \\
{[\mathrm{EDTA}] \text { or }[\mathrm{SC}]=50 \mathrm{mM}} \\
\mathrm{H}_{2} \mathrm{O}_{2}: \mathrm{CA}=5.8: 1\end{array}$ & $\begin{array}{c}80 \mathrm{mg} \mathrm{kg}^{-1} \\
2,4-\mathrm{DMP}\end{array}$ & $\begin{array}{l}\text { EDTA: } 7.7 \\
\text { l-AA: } 5.8 \\
\text { GA: } 5.5 \\
\text { CitrA: } 5.2 \\
\text { SC: } 8.3 \\
\text { SCm: } 7\end{array}$ & $\begin{array}{c}\text { Spiked soil } \\
\text { (3 calcareous loamy } \\
\text { sand soils with SOM: } \\
\text { S1: } 15.2 \% \\
\text { S2:10.1\% } \\
\text { S3: } 6.4 \%) \\
\text { Batch slurry }\end{array}$ & 2 & $\begin{array}{l}\text { (a) } 24 \mathrm{~h} \\
\text { (b) } 1 \mathrm{~h} \\
\text { (c) } 1 \mathrm{~h}\end{array}$ & 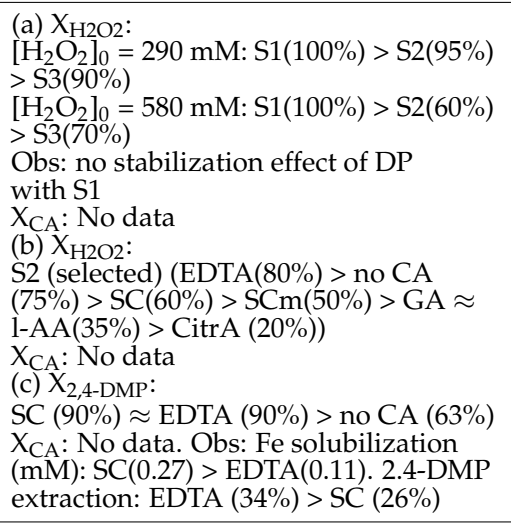 & [35] \\
\hline SC & 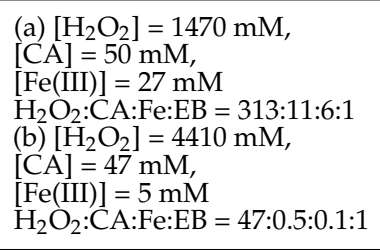 & $\begin{array}{c}\text { (a) } 1996 \mathrm{mg} \mathrm{kg}^{-1} \\
\mathrm{~EB} \\
\text { (b) } 19960 \mathrm{mg} \mathrm{kg}^{-1} \\
\mathrm{~EB}\end{array}$ & 6 & $\begin{array}{l}\text { Spiked soil } \\
\text { Batch slurry }\end{array}$ & 2 & $120 \mathrm{~h}$ & $\begin{array}{l}\text { (a) } \mathrm{X}_{\mathrm{EB}}: 100 \% \\
\mathrm{X}_{\mathrm{H} 2 \mathrm{O}}: 100 \% \\
\mathrm{X}_{\mathrm{CA}}: 80 \% \\
\text { Obs: soluble Fe decays as citrate } \\
\text { disappears, } \mathrm{H}_{2} \mathrm{O}_{2} \text { and EB disappeared } \\
\text { faster when [Fe(III)] was higher. } \\
\text { (b) } \mathrm{X}_{\mathrm{EB}}: 60 \% \\
\mathrm{X}_{\mathrm{H} 2 \mathrm{O} 2}: 100 \% ; \mathrm{X}_{\mathrm{CA}}: 100 \%\end{array}$ & [50] \\
\hline $\begin{array}{l}\mathrm{KH}_{2} \mathrm{PO}_{4} \\
\text { EDTA } \\
\text { HAs (commercial and } \\
\text { from compost) }\end{array}$ & $\begin{array}{l}{\left[\mathrm{KH}_{2} \mathrm{PO}_{4}\right]=59 \mathrm{mM},} \\
{[\mathrm{EDTA}]=10 \mathrm{mM}} \\
{[\mathrm{HAs}]=1000 \mathrm{mg} / \mathrm{L}} \\
{\left[\mathrm{H}_{2} \mathrm{O}_{2}\right]=1765 \mathrm{mM}} \\
\text { Natural Fe species present in } \\
\text { the soil }\end{array}$ & $\begin{array}{c}5 \mathrm{mg} \mathrm{kg}^{-1} \\
\text { chlorophenol }\end{array}$ & $\begin{array}{c}\mathrm{HA} \text { and } \\
\mathrm{KH}_{2} \mathrm{PO}_{4}: 5.5 \\
\text { EDTA: } 8\end{array}$ & $\begin{array}{c}\text { Spiked soil } \\
\left(\mathrm{Fe}=29.7 \mathrm{~g} \mathrm{~kg}^{-1} \text { and }\right. \\
\left.\mathrm{Mn}=0.8 \mathrm{~g} \mathrm{~kg}^{-1}\right) \\
\text { Batch slurry }\end{array}$ & 5 & $3 \mathrm{~h}$ & $\begin{array}{l}\mathrm{X}_{\text {chlorophenol }}: \mathrm{HA}_{\text {extracted }}(95 \%) \approx \\
\text { EDTA }(95 \%)>>\mathrm{HA}_{\text {commercial }}(90 \%)> \\
\mathrm{KH}_{2} \mathrm{PO}_{4}(78 \%)>\text { no CA }(76 \%) \\
\mathrm{X}_{\mathrm{H}_{2} \mathrm{O} 2}(24 \mathrm{~h}): \text { no CA }(95 \%)>\text { EDTA }(90 \%) \\
>\mathrm{HA}(62 \%)>\mathrm{KH}_{2} \mathrm{PO}_{4}(78 \%) \\
\mathrm{X}_{\mathrm{CA}}: \text { No data }\end{array}$ & [101] \\
\hline
\end{tabular}

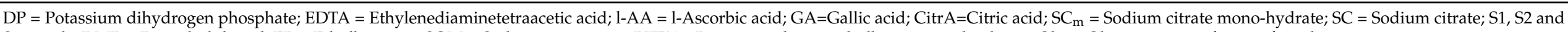
S3 = soils; DMP = Dimethylphenol; EB = Ethylbenzene; SOM = Soil organic matter; BTEX = Benzene, toluene, ethylbenzene and xylenes. Obs = Observations, n.f. = not found 
Vicente et al. analyzed the influence of a $\mathrm{H}_{2} \mathrm{O}_{2}$-stabilizer (potassium dihydrogen phosphate, DP) and different CAs on the consumption of $\mathrm{H}_{2} \mathrm{O}_{2}$ and the remediation efficiency of a soil contaminated with 2,4-dimethylphenol (2,4-DMP) [35]. The application of DP reduced the $\mathrm{H}_{2} \mathrm{O}_{2}$ consumption by $40 \%$ in soils with high surface area and low SOM content. On the contrary, these authors found a negligible stabilization effect when treating soils with high SOM content, consistent with that previously reported in Section 3.1. Moreover, these authors studied the destabilization effect of $\mathrm{H}_{2} \mathrm{O}_{2}$ in the presence of different $\mathrm{CAs}$, reporting the following order: EDTA $<\mathrm{SC}<\mathrm{SCm}<1$-ascorbic acid (l-AA) $\approx$ gallic acid $(\mathrm{GA})<$ CitrA. The high oxidant consumption when using EDTA can be explained by attending to the high value of the stability constant of Fe(III)-EDTA (Table 2).

On the other hand, the major $\mathrm{H}_{2} \mathrm{O}_{2}$ stabilization effect achieved in the case of CitrA can be related to the low $\mathrm{pH}$ obtained in this $\mathrm{CA}$ /soil suspension, as can be seen in Table 5, suggesting that the $\mathrm{pH}$ of the system notably influences $\mathrm{H}_{2} \mathrm{O}_{2}$ stability. Regarding pollutant removal efficiency (only studied in the presence of EDTA and SC), these authors reported that the addition of EDTA or SC increased the degradation of the pollutant (2,4-DMP) by $27 \%$. The results indicated that the presence of these CAs favors the desorption of the entrapped pollutant and solubilizes part of the iron from the soil, resulting in a significant increase in 2,4-DMP degradation [35].

Similarly, Pardo et al. reported an increase in ethylbenzene (EB) conversion when SC was used as CA [50]. Besides, citrate as sodium salt controlled the $\mathrm{H}_{2} \mathrm{O}_{2}$ decomposition rate and maintained a neutral $\mathrm{pH}$. However, the concentration of soluble iron decayed as citrate disappeared from the reaction media [50]. This fact highlights the importance of studying separately the concentration of the chemicals (CA and catalyst) both dissolved in the aqueous phase and adsorbed onto the soil, aspects rarely reported in the literature.

The remediation of soils artificially contaminated with 3-chlorophenol was explored using extracted humic acids from compost as $\mathrm{CA}$ and $\mathrm{H}_{2} \mathrm{O}_{2}$ stabilizer [101]. The extracted HAs allowed to achieve a $\mathrm{H}_{2} \mathrm{O}_{2}$ lifetime close to the one obtained with a traditional stabilizing agent, being effective in removing the pollutant $(95 \%$ in the test carried out with $1000 \mathrm{mg} / \mathrm{L}$ of extracted HAs at $3 \mathrm{~h}$ of reaction time). The contaminated soils were also treated by MF using a traditional chelating agent (EDTA) and commercial HAs. The test performed with EDTA led to more equivalent results than extracted HAs, whereas the 3-chlorophenol removal achieved with commercial HAs was lower [101].

Therefore, based on the limited results found for this group of contaminants, the CAs recommended for BTEX and phenolics compounds removal from soil are: Citrate > HAs > EDTA. Citrate (as CitrA and SC) stands up as a more suitable stabilizer and CA than EDTA in the MF process because the last one reacts with hydroxyl radicals 10 times faster than citrate (see kinetic constants, corresponding to Equation (24), summarized in Table 3), showing high $\mathrm{OH}^{\bullet}$ scavenging effect. Moreover, the citrate use leads to higher iron solubilization, a hydrogen peroxide stabilization effect [35], and entails fewer environmental problems than EDTA. Finally, it is preferable to use citrate as sodium salt (SC) instead of the acidic form (CitrA) because this $\mathrm{CA}$ promotes a near-neutral soil $\mathrm{pH}$ during the reaction, minimizing the environmental impact of the remediation technique $[35,50]$. On the other hand, although similar contaminant removal was obtained with HAs and EDTA [101], using compounds with lower environmental impacts is highly recommended, as is the case of HAs.

A second dose of oxidant and Fe-citrate increases the target pollutant degradation [151], although this option would be only recommended when treating recalcitrant pollutants with low hydroxyl radical reaction rate constants. In this way, Liang et al. reported that among four BTEX compounds, benzene was the most resistant to oxidation in the aqueous phase [152], the reaction rate constant of benzene with hydroxyl radicals $\left(k_{\text {benzene, }}{ }^{\bullet}\right.$ $=6.6 \times 10^{8} \mathrm{M}^{-1} \mathrm{~s}^{-1}$ [145]) being one order of magnitude lower than those of toluene, ethylbenzene, and xylene, as summarized in Table 4 . In this study, benzene conversion increased when using different CAs, following the descending order (at the same operating conditions): CitrA $(100 \%)>$ EDTA $(50 \%)$ [152], which is in line with the above mentioned. 
An alternative to EDTA is the use of the environmentally friendly ligand EDDS. Huang et al. demonstrated the effective removal of Bisphenol-A by Fenton-EDDS application when treating polluted waters [47]. In this way, it would be interesting to test the efficacy of the EDDS removing BTEX and phenolic compounds in real soil matrices, which has not been reported in the literature so far. However, it should be considered that the reaction rate constant of EDDS with $\mathrm{OH}^{\bullet}$ is relatively high $\left(k_{\mathrm{EDDS}, \mathrm{OH}}{ }^{\bullet}=2-5.2 \times 10^{8} \mathrm{M}^{-1} \mathrm{~s}^{-1}\right.$ [47], Table 3) and, therefore, EDDS application would not be recommended for the remediation of highly refractory pollutants, such as benzene $\left(k_{\text {benzene, } \mathrm{OH}^{\bullet}}=6.6 \times 10^{8} \mathrm{M}^{-1} \mathrm{~s}^{-1}\right.$ [145], Table 4), due to the high possibility for competition between EDDS and the pollutant for the hydroxyl radicals formed (Equations (23) and (24)).

\subsubsection{Polycyclic Aromatic Hydrocarbons (PAHs)}

The polycyclic aromatic hydrocarbons (PAHs) contamination is of great concern due to the high toxicity, mutagenic and carcinogenic effects of these pollutants. PAHs can be strongly adsorbed to soil organic matter, encapsulated in soil mineral, and presented in the form of dense non-aqueous phase liquid (DNAPL), which makes the remediation process difficult [153]. Therefore, substantial research has been undertaken to develop efficient techniques to remove persistent PAHs from soils or sediments [28]. The most commonly studied PAHs are: naphthalene (NAP), phenanthrene (PHE), benzo(a)fluoranthene (Baft), 2-methylnaphthalene, anthracene (ANT), benzo(k)fluoranthene (Bkf), fluoranthene (FLUT), benzo(a)pyrene (BaP), acenaphthylene (ACEL), pyrene (PYR), indeno (1,2,3-cd)pyrene (INDE), acenaphthene (ACE), fluorene (FLU), dibenzo(a,h)anthracene (BafT), chrysene (CHR), benzo (g,h,i)perylene (BghiP), and benzo(a)anthracene (BaA) [154]. A wide variety of CAs has been explored in MF process to remediate PAHs (Table 6), including sodium pyrophosphate (SP), EDTA, oxalate (as oxalic acid (OA) and sodium oxalate (SO)), citrate (as citric acid (CitrA) and sodium citrate (SC)), malic acid (MA), humic acid (HA), cyclodextrins (CD), catechol (CC), and gallic acid (GA), most of which are discussed in Section 2.

Venny et al. performed a comparison of various organic and inorganic CAs to assist MF oxidation [55]. Their results revealed that inorganic SP was superior in pollutant removal efficiency (79.5\% and $89.1 \%$ of conversion for PHE and FLUT, respectively) and the application of SC resulted in lower PAH removal (58.5\% and $57.5 \%$ of pollutant conversion for PHE and FLUT, respectively at $24 \mathrm{~h}$ of reaction time) (Table 6). Similar findings were obtained by Jorfi et al., reporting the maximum pollutant removal efficiency by employing SP, $93 \%$, compared to $86 \%, 75 \%, 72 \%$, and $71 \%$ achieved at the same conditions for EDTA, SC, HA and FA, respectively [85]. In both studies, the higher conversion of PAHs achieved when using an inorganic CA (SP) than the organic ones was probably due to the lower competition of this ligand for the $\mathrm{OH}^{\bullet}$, as indicated by the respective $k_{\mathrm{L}, \mathrm{OH}}{ }^{\bullet}$ and $k_{\mathrm{Fe}-\mathrm{L}, \mathrm{OH}}{ }^{\bullet}$ values for these CAs in Table 3. Contrary to the results mentioned above $[55,85]$, the use of inorganic CAs (SP and DP) was not effective in hydrogen peroxide activation in the study carried out by Shih et al., where the PAHs degradation pursued the following descending order: SC $(68 \%)>\mathrm{OA} \approx \mathrm{DP}(51 \%)>$ EDTA $(44 \%)>\mathrm{SO}(36 \%)>\mathrm{SP}(32 \%)$ (Table 6) [57]. Different factors can justify such variations in the results reported in the literature.

Firstly, the differences in the chemical composition of the soil may play a crucial role, as previously mentioned in Section 3.1.2. In this way, although pyrophosphate is not oxidized by hydroxyl radicals [73], when phosphates are added to soils containing calcium carbonate adsorption, and precipitation of phosphate-containing minerals occur, which in turn reduced soil permeability and led to the ineffectiveness of the Fenton treatment [155]. Thus, SP and DP may combine with both natural mineral components of soils and Fe(III) in solution in the aqueous phase, forming stable complexes. However, the Fe-monophosphate complex is insoluble. Hence, the concentration of dissolved Fe(III) decreases with time [54], reducing the efficiency of inorganic CAs in some matrix soils. In this way, as stated previously in Section 3.1.4, future studies should investigate the interactions of CAs and Fe-L formed with soil and the different soil components, as well as the CA and Fe-L 
diminution from the solution related to a possible degradation, or adsorption mechanisms, due to the strong influence of these factors on process performance.

Secondly, the significant differences obtained in the pollutant removal may be explained by the concentration of the inorganic CA (SP) used in these studies. For example, in the work carried out by Venny et al., SP was added in a CA:Fe molar ratio of 0.8:1 [55], whereas the ratio used by Shih et al. was 5:1 [57]. At high SP concentration, the strong steric hindrance impeded the interaction between oxidant and $\mathrm{Fe}$ (II)-SP, decreasing the yield of $\mathrm{OH}^{\bullet}$. Moreover, the reduction rate of $\mathrm{Fe}(\mathrm{III})-\mathrm{SP}$ also decreases [52], which may be the reason for the low efficiency obtained by Shih et al. for the use of SP in the MF process [57].

Regarding the use of SC and CitrA, controversial results have been found in the literature. For example, Shih et al. found that SC was the most effective of four CAs used to stabilize ferrous iron [57]. However, the use of this CA, led to poor results for other researchers [55]. As stated above, the CA:Fe ratio is an important factor conditioning the nature and concentration of the oxidizing species generated. For example, the relatively low stability constant of Fe-citrate requires high CA:Fe ratios, which justifies the low pollutant conversions achieved in the study carried out by Venny et al. by using a low SC:Fe ratio of 0.5:1 [55]. In the same way, the degradation rate of PAHs did not significantly increase with the addition of CitrA [137], which was justified by the low CitrA:Fe molar ratio employed in this case (0.5:1). However, although the use of high citrate:Fe ratios (from 1:1 to $25: 1)$ coincides with high contaminant conversion values $[57,151,156]$, if this CA is present in relatively high concentrations, it can also compete with the pollutant for hydroxyl radicals $\left(k_{\mathrm{Fe}-\text { citrate, } \mathrm{OH}}{ }^{\bullet}=1.2 \times 10^{8} \mathrm{M}^{-1} \mathrm{~s}^{-1}\right.$ and $k_{\text {citrate, } \mathrm{OH}}{ }^{\bullet}=5 \times 10^{7}-3.2 \times 10^{8} \mathrm{M}^{-1} \mathrm{~s}^{-1}$, as summarized in Table 3), reducing the pollutant degradation efficiency [73]. Therefore, an optimal concentration of citrate should be high enough to favor the formation of the Fe-citrate complex but not too much to cause an important scavenging effect on the $\mathrm{OH}^{\bullet}$ produced.

As in the case of the previous CAs, controversial results have been found in the literature regarding the use of EDTA. As summarized in Table 6, some authors have obtained good results when using this CA for PAHs degradation [55,85]. However, no significant improvement associated with its use was observed in other studies $[57,157]$. The differences could reside in the presence of heavy metals (HM) in real contaminated sediments, with higher stability constants with EDTA than iron $\left(\log \beta_{\mathrm{HM}}\right.$-EDTA $\left.>\log \beta_{\mathrm{Fe}-\mathrm{EDTA}}\right)$, and thus being responsible for the moderate efficacy of this CA in the mentioned works.

As for the case of $\mathrm{SC}$, the slower rate of PAHs degradation when using OA compared to SP and EDTA in the study of Venny et al. could be attributed to the fact that higher $\mathrm{CA}:$ Fe molar ratio than the used (OA:Fe $>1)$ is needed, owing to the weaker complexation ability of oxalate with iron ions in contrast to SP and EDTA (Table 2). Accordingly, better results were obtained with OA compared to EDTA and SP by Shih et al., who used a higher $\mathrm{CA}: \mathrm{Fe}$ molar ratio (OA:Fe = 2:1) [57].

Regarding the use of less common organic CAs (not covered in Section 2), such as catechol (CC), the addition of this $C A$ resulted in a significant increase in the degradation of heavy PAHs [158]. On the contrary, in the study carried out by Nam et al., the addition of CC and GA resulted in a decline in the overall performance of the process compared to the unmodified Fenton process [37]. However, the system's $\mathrm{pH}$ was maintained at neutral values, which allowed the combination of the chemical oxidation process with subsequent biodegradation. In this way, combined MF and biodegradation resulted in approximately $98 \%$ removal of low molecular weight PAHs and 70\% removal of high molecular weight PAHs.

In addition to all the above, excellent performance in the remediation of PAHscontaminated soils has been reported by means of persulfate enhanced MF (PS-MF) treatment $[55,158]$. These findings imply the compatibility of $\mathrm{SO}_{4}{ }^{\bullet-}$ radical anion (coming from PS decomposition) in enhancing the MF treatment coupled with CAs even at remarkably low concentration. However, there is not much information in the bibliography regarding the application of this treatment and further research is required. 
Table 6. Research studies for PAHs degradation in soils using MF process.

\begin{tabular}{|c|c|c|c|c|c|c|c|c|}
\hline Tested CA & $\begin{array}{l}\text { Treatment and Optimal } \\
\text { Reagents Dose } \\
\text { Concentration (mM) and } \\
\text { Molar Ratio }\end{array}$ & $\begin{array}{l}\text { Pollutant cc. } \\
\left(\mathrm{mg} \mathrm{kg}^{-1}\right)\end{array}$ & $\mathrm{pH}$ & $\begin{array}{l}\text { Soil Type/Reaction } \\
\text { System }\end{array}$ & $\mathrm{V}_{\mathrm{L}} / \mathrm{W}(\mathrm{mL} / \mathrm{g})$ & Reaction Time & Conversion (\%) & Ref \\
\hline $\begin{array}{l}\text { SP } \\
\text { EDTA } \\
\text { OA } \\
\text { SC } \\
\text { MA }\end{array}$ & $\begin{array}{l}\text { (a) Fenton } \\
{\left[\mathrm{H}_{2} \mathrm{O}_{2}\right]=480 \mathrm{mM},} \\
{[\mathrm{Fe}(\mathrm{IIII}]=60 \mathrm{mM}} \\
\mathrm{H}_{2} \mathrm{O}_{2}: \mathrm{SP}: \mathrm{EDTA} \mathrm{OA}: \mathrm{SC}: \mathrm{MA}: \mathrm{Fe}= \\
\text { 8:0.8:0.7:0.7:0.5:0.5:1 } \\
\text { (b) Fenton + PS } \\
{\left[\mathrm{H}_{2} \mathrm{O}_{2}\right]=324 \mathrm{mM},[\mathrm{PS}]=120 \mathrm{mM},} \\
{[\mathrm{CA}]=60 \mathrm{mM},[\mathrm{Fe}(\mathrm{III})]=60 \mathrm{mM}} \\
\text { PS: } \mathrm{H}_{2} \mathrm{O}_{2}: \mathrm{CA}: \mathrm{Fe}=2: 5.4: 1: 1\end{array}$ & $\begin{array}{l}1000 \mathrm{mg} \mathrm{kg}^{-1} \text { of } \\
\text { PHE and FLUT }\end{array}$ & 7 & $\begin{array}{l}\text { Spiked soil } \\
\text { (loamy sand) } \\
\text { Batch slurry }\end{array}$ & 3 & $24 \mathrm{~h}$ & $\begin{array}{l}\text { (a) } \mathrm{X}_{\mathrm{PHE}}: \mathrm{SP}(79.5 \%)>\operatorname{EDTA}(78.7 \%)>\mathrm{OA}(73.1 \%)> \\
\text { MA }(68.5 \%)>\mathrm{SC}(58.5 \%) \\
\mathrm{X}_{\mathrm{FLUT}} \mathrm{SP}(89.1 \%)>\operatorname{EDTA}(78.5 \%)>\mathrm{MA}(76.0 \%)> \\
\mathrm{OA}(72.7 \%)>\mathrm{SC}(57.2 \%) \\
\mathrm{X}_{\mathrm{H} 2 \mathrm{O} 2}(3 \mathrm{~h}): \mathrm{SP}(10 \%)<\mathrm{OA}(95 \%)<\mathrm{SC}(100 \%)< \\
\text { MA }(100 \%)<\mathrm{EDTA}(100 \%) \\
\mathrm{X}_{\mathrm{CA}}: \text { No data } \\
\text { (b) } \mathrm{X}_{\mathrm{PHE}}: \mathrm{SP}(95.4 \%) \\
\mathrm{X}_{\mathrm{FLUT}}: \mathrm{SP}(92.3 \%) \\
\mathrm{X}_{\mathrm{H} 2 \mathrm{O} 2} \text { : No data, } \mathrm{X}_{\mathrm{CA}} \text { : No data }\end{array}$ & [55] \\
\hline $\begin{array}{l}\text { SP } \\
\text { SC } \\
\text { EDTA } \\
\text { FA } \\
\text { HA }\end{array}$ & $\begin{array}{l}{\left[\mathrm{H}_{2} \mathrm{O}_{2}\right]=300 \mathrm{mM},[\mathrm{CA}]=\text { No data, }} \\
\text { [iron nano-oxide] }=30 \mathrm{mM} \\
\mathrm{H}_{2} \mathrm{O}_{2}: \mathrm{Fe}=10\end{array}$ & $100 \underset{\text { PYR }}{\mathrm{mg} \mathrm{kg}^{-1}}$ & 7 & $\begin{array}{l}\text { (a) Spiked soil } \\
\text { (silty sand) } \\
\text { (b) Aged soil (1 year) } \\
\text { (c) Real soil } \\
\text { Batch slurry }\end{array}$ & 3 & $6 \mathrm{~h}$ & $\begin{array}{l}\text { (a) } \mathrm{X}_{\mathrm{PYR}}: \mathrm{SP}(93 \%)>\operatorname{EDTA}(86 \%)>\mathrm{SC}(75 \%)>\mathrm{HA}(72 \%) \\
>\text { FA(71\%) } \\
\text { (b) } \mathrm{X}_{\mathrm{PYR}}: \mathrm{SP}(91 \%) \\
\text { (c) } \mathrm{X}_{\mathrm{PYR}}: \mathrm{SP}(43 \%) \\
\mathrm{X}_{\mathrm{H} 2 \mathrm{O} 2} \text { : No data, } \mathrm{X}_{\mathrm{CA}} \text { : No data }\end{array}$ & [85] \\
\hline $\begin{array}{l}\text { SP } \\
\text { SO } \\
\text { EDTA } \\
\text { OA } \\
\text { SC } \\
\text { DP }\end{array}$ & $\begin{array}{l}{\left[\mathrm{H}_{2} \mathrm{O}_{2}\right]=50 \mathrm{mM}} \\
{[\mathrm{Fe}(\mathrm{II})]=0.25-2.5 \mathrm{mM}} \\
\text { SP:EDTA:SO:OA:SC:MP:Fe = } \\
5: 5: 2: 2: 4: 2: 1 \\
\mathrm{CA}: \mathrm{Fe}(w: w)=1: 1\end{array}$ & $\begin{array}{l}4.23 \mathrm{mg} \mathrm{kg}^{-1} \\
\text { PAHs (16 types) }\end{array}$ & 7.2 & $\begin{array}{l}\text { Real } \\
\text { sediments } \\
\text { TOC }=8.5 \% \\
\text { SOM }=10.5 \% \\
\text { Batch slurry }\end{array}$ & 25 & $24 \mathrm{~h}$ & $\begin{array}{l}\mathrm{X}_{\mathrm{PAHs}}: \mathrm{SC}(68 \%)>\mathrm{OA} \approx \mathrm{DP}(50.5 \%)>\operatorname{EDTA}(44 \%)> \\
\mathrm{SO}(36 \%)>\mathrm{X}_{\mathrm{SP}}(32 \%) \\
\mathrm{X}_{\mathrm{H} 2 \mathrm{O} 2}: \text { No data, } \mathrm{X}_{\mathrm{CA}}: \text { No data }\end{array}$ & [57] \\
\hline CitrA & $\begin{array}{l}{\left[\mathrm{H}_{2} \mathrm{O}_{2}\right]=1800 \mathrm{mM}(15 \text {-fold } \mathrm{SMR})} \\
{[\mathrm{CA}]=90 \mathrm{mM},[\mathrm{Fe}(\mathrm{II})]=180 \mathrm{mM}} \\
\mathrm{H}_{2} \mathrm{O}_{2}: \mathrm{CA}: \mathrm{Fe}=20: 1: 2\end{array}$ & $\begin{array}{l}1550 \mathrm{mg} \mathrm{kg}^{-1} \\
\text { PAHs (16 types) }\end{array}$ & 7.4 & $\begin{array}{l}\text { Real soil } \\
\text { (sandy loam) } \\
\text { Batch slurry }\end{array}$ & 2 & $4 \mathrm{~d}$ & $\begin{array}{l}\mathrm{X}_{\mathrm{PAHs}}: 45 \% \\
\mathrm{X}_{\mathrm{H} 2 \mathrm{O} 2}: \text { No data, } \mathrm{X}_{\mathrm{CA}}: \text { No data } \\
\text { Obs: cyclodextrin and/or CAs did not improve the } \\
\text { oxidation process. Limiting factors: low } \\
\text { PAHs availability }\end{array}$ & [137] \\
\hline EDTA & $\begin{array}{l}{\left[\mathrm{H}_{2} \mathrm{O}_{2}\right]=570 \mathrm{mM},} \\
{[\mathrm{CAA}]=[\mathrm{Fe}(\mathrm{II})]=26 \mathrm{mM}} \\
\mathrm{H}_{2} \mathrm{O}_{2}: \mathrm{CA}: \mathrm{Fe}=22: 1: 1\end{array}$ & $\begin{array}{l}1200 \text { and } \\
2800 \mathrm{mg} \mathrm{kg}^{-1} \\
\text { PHE and PYR }\end{array}$ & 5.2 & $\begin{array}{l}\text { Aged soil } \\
\left(15 \mathrm{month}^{2}\right) \\
\left(109 \mathrm{mg} \mathrm{kg}^{-1} \mathrm{Fe}\right) \\
\text { Batch slurry }\end{array}$ & 2 & $7 \mathrm{~d}$ & $\begin{array}{l}\mathrm{X}_{\mathrm{PHE}}: 10 \% \\
\text { X }_{\mathrm{PYR}}: 37 \% \\
\mathrm{X}_{\mathrm{H} 2 \mathrm{O} 2}: \text { No data, } \mathrm{X}_{\mathrm{CA}}: \text { No data }\end{array}$ & [157] \\
\hline EDTA & $\begin{array}{l}{\left[\mathrm{H}_{2} \mathrm{O}_{2}\right]=1730 \mathrm{mM}} \\
{[\mathrm{CA}]=0.08 \mathrm{mM}} \\
{[\mathrm{Fe}(\mathrm{III})]=2.1 \mathrm{mM}} \\
\mathrm{H}_{2} \mathrm{O}_{2}: \mathrm{CA}: \mathrm{Fe}=21900: 1: 27\end{array}$ & $\begin{array}{l}21420 \mathrm{mg} \mathrm{kg}^{-1} \\
\text { PAHs (16 types) }\end{array}$ & 8 & $\begin{array}{c}\text { Real soil } \\
\text { Batch slurry }\end{array}$ & 2.5 & $2 \mathrm{~d}$ & $\begin{array}{l}\mathrm{X}_{\mathrm{PAHS}}: 71.3 \% \\
\mathrm{X}_{\mathrm{H} 2 \mathrm{2}}: 100 \%(2 \mathrm{~h}) \\
\mathrm{X}_{\mathrm{CA}}: \text { No data } \\
\text { Obs: PAHs with } 5 \text { and } 6 \text { rings showed lower } \\
\text { removal rates }\end{array}$ & [159] \\
\hline
\end{tabular}


Table 6. Cont.

\begin{tabular}{|c|c|c|c|c|c|c|c|c|}
\hline Tested CA & $\begin{array}{c}\text { Treatment and Optimal Reagents } \\
\text { Dose } \\
\text { Concentration (mM) and } \\
\text { Molar Ratio }\end{array}$ & $\begin{array}{l}\text { Pollutant cc. } \\
\left(\mathrm{mg} \mathrm{kg}^{-1}\right)\end{array}$ & $\mathrm{pH}$ & $\begin{array}{c}\text { Soil Type/Reaction } \\
\text { System }\end{array}$ & $\mathrm{V}_{\mathrm{L}} / \mathrm{W}(\mathrm{mL} / \mathrm{g})$ & Reaction Time & Conversion $(\%)$ & Ref \\
\hline $\begin{array}{l}15 \text { CAs } \\
\text { tested }{ }^{*}: \\
\text { CC and GA } \\
\text { selected }\end{array}$ & $\begin{array}{l}{\left[\mathrm{H}_{2} \mathrm{O}_{2}\right]=882 \mathrm{mM},[\mathrm{CC}]=37 \mathrm{mM}} \\
{[\mathrm{GA}]=41 \mathrm{mM},[\mathrm{Fe}(\mathrm{II})]=35 \mathrm{mM}} \\
\mathrm{H}_{2} \mathrm{O}_{2}: \mathrm{CA}: \mathrm{Fe}=24: 1: 1\end{array}$ & $\begin{array}{l}3724 \mathrm{mg} \mathrm{kg}^{-1} \text { PAHs } \\
\text { (NAP, FLU, PHE, } \\
\text { ANT, PYR, } \\
\text { CHR, BaP) }\end{array}$ & $6-6.5$ & $\begin{array}{c}\text { Real soil (loamy sand) } \\
\text { Batch slurry }\end{array}$ & 4 & $24 \mathrm{~h}$ & $\begin{array}{l}\text { CC: } \mathrm{X}_{\mathrm{NAP}}(84.7 \%), \mathrm{X}_{\mathrm{FLU}}(32.8 \%), \mathrm{X}_{\mathrm{PHE}}(31.7 \%), \\
\mathrm{X}_{\mathrm{ANT}}(29.2 \%), \mathrm{X}_{\mathrm{PYR}}(41.7 \%), \mathrm{X}_{\mathrm{CHR}}(12 \%), \mathrm{X}_{\mathrm{BaP}} \\
(45.2 \%) \\
\text { GA: } \mathrm{X}_{\mathrm{NAP}}(89 \%), \mathrm{X}_{\mathrm{FLU}}(36.2 \%), \mathrm{X}_{\mathrm{PHE}}(29.9 \%), \mathrm{X}_{\mathrm{ANT}} \\
(33.2 \%), \mathrm{X}_{\mathrm{PYR}}(41.1 \%), \mathrm{X}_{\mathrm{CHR}}(8.9 \%), \mathrm{X}_{\mathrm{BaP}}(50.4 \%) \\
\mathrm{X}_{\mathrm{H} 2 \mathrm{O} 2}: \mathrm{No} \mathrm{Nota}, \mathrm{X}_{\mathrm{CA}}: \text { No data } \\
\text { Obs: } \mathrm{X}_{\text {pollutant }}>\text { in Fenton }(\mathrm{pH}=2-3 \text { acid soil) than } \\
\text { MF but MF allowed the combination of the } \\
\text { treatment with biodegradation. }\end{array}$ & [37] \\
\hline $\mathrm{CC}$ & $\begin{array}{l}\text { (a) Fenton } \\
{\left[\mathrm{H}_{2} \mathrm{O}_{2}\right]=100 \mathrm{mM},[\mathrm{CA}]=2 \mathrm{mM},} \\
{[\mathrm{F}(\mathrm{II})]=2 \mathrm{mM}} \\
\mathrm{H}_{2} \mathrm{O}_{2}: \mathrm{CA}: \mathrm{Fe}=50: 1: 1 \\
\text { (b) Fenton }+P S \\
{\left[\mathrm{H}_{2} \mathrm{O}_{2}\right]=50 \mathrm{mM},[\mathrm{PS}]=50 \mathrm{mM},} \\
{[\mathrm{CA}]=2 \mathrm{mM},[\mathrm{Fe}(\mathrm{III}]=2 \mathrm{mM}} \\
\mathrm{PS}: \mathrm{H}_{2} \mathrm{O}_{2}: \mathrm{CA}: \mathrm{Fe}=25: 25: 1: 1\end{array}$ & $\begin{array}{l}16 \text { PAHs (light } \\
700 \mathrm{mg} \mathrm{kg}^{-1} \text {, heavy } \\
1700 \mathrm{mg} \mathrm{kg}^{-1} \text { ) }\end{array}$ & 7.7 & $\begin{array}{c}\text { Real soil } \\
\text { Batch slurry }\end{array}$ & 3.3 & n.f. & $\begin{array}{l}\text { (a) Ligth: } 98 \% \text {, Heavy: } 97 \% \text {, Total PAHs: } 98 \% \\
\text { (b) Ligth: } 93 \%, \text { Heavy: } 90 \% \text {, Total PAHs: } 92 \% \\
\mathrm{X}_{\mathrm{H} 2 \mathrm{O} 2} \text { : No data, } \mathrm{X}_{\mathrm{CA}} \text { : No data }\end{array}$ & [158] \\
\hline
\end{tabular}

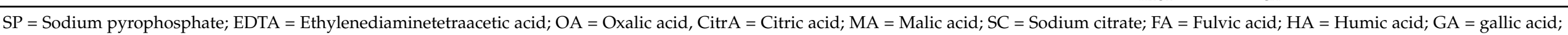

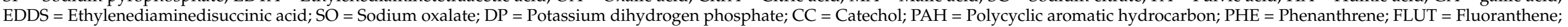

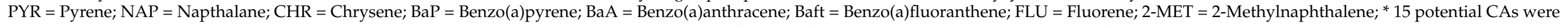
tested. Among them, catechol (CC) and gallic acid (GA) were chosen based on the degradation efficiency of PAHs. Obs = Observations, n.f. = not found. 


\subsubsection{Total Petroleum Hydrocarbons (TPHs)}

Total petroleum hydrocarbons (TPHs) are one of the most common pollutants in the environment. TPHs include a broad family of several hundred hydrocarbon compounds, including volatile petroleum hydrocarbons (VPHs, $\mathrm{C}_{2}-\mathrm{C}_{5}$ ) and extractable petroleum hydrocarbons (EPHs, $\mathrm{C}_{6}-\mathrm{C}_{40}$ ) that originally come from crude oil, which is used to make petroleum products: gasoline, kerosene, diesel fuels, jet fuels, mineral-based motor oils, fuel oils, etc.

Conflicting results on the use of citrate in MF process for the remediation of TPHs contaminated soils have been found in the literature. As summarized in Table 5, some authors have obtained interesting results when using CitrA [38,72,74,160,161]. Chang et al. reported that the stabilizing effect order for different $C A s$ on the decomposition of hydrogen peroxide and TPHs removal was: Citrate $>$ Phosphate $>$ EDDS $>$ EDTA, as summarized in Table 7 [72]. These results agree with those obtained by Vicente et al., who reported a higher $\mathrm{H}_{2} \mathrm{O}_{2}$ stabilizing effect and chelating efficacy of citrate than EDTA when treating 2,4-DMP polluted soils [35]. In contrast, Pardo et al. stated that higher TPHs removal efficiencies were obtained (up to $75 \%$ ) after the treatment of a diesel-polluted soil in the absence of citrate (coming from SC) [51] than in the presence of this CA $\left(\mathrm{X}_{\mathrm{TPHs}}=37 \%\right)$. This fact could be explained by the $\mathrm{pH}$ of the system $(\mathrm{pH}=6)$. As indicated in Citrate/Citric acid (CitrA) Section (Table 3), as the $\mathrm{pH}$ of the reaction medium increases, the rate constant of citrate with $\mathrm{OH}^{\bullet}$ increases. Consistently, at these conditions, the CA (citrate) competes with the pollutant for the hydroxyl radicals generated, decreasing the efficiency of the remediation treatment [51].

For their part, Ouriache et al. and Polli et al. suggested that the use of EDTA improved the removal of TPHs from polluted soils $[84,162]$. On the contrary, other authors reported that the presence of EDTA in the MF process was not beneficial for the degradation of these pollutants (hydrocarbon fractions treated: $C_{10}-C_{40}$ and $C_{10}-C_{16}$ ) [81,163]. All these studies were conducted with real contaminated soils. However, such variations in the results obtained can be justified by the differences in the SOM and total organic carbon (TOC) content of the soils treated. Therefore, the EDTA application has been considered suitable for remediating soils with relatively low TOC and SOM contents [84,162].

Conversely, when soil TOC and SOM content was higher than $10 \%$, the efficiency of the treatment decreased by adding EDTA $[81,163]$. This fact can be attributed to the formation of the complex $\mathrm{Fe}(\mathrm{III})-\mathrm{SOM}$, which presents a stability constant 20 orders of magnitude lower than Fe(III)-EDTA (Table 3). Fe(III)-EDTA is less available for decomping hydrogen peroxide than Fe(III)-SOM. Thus, the presence of EDTA inhibits the participation of native Fe oxides in the Fenton reactions, decreasing the efficiency of remediation treatment. These findings highlight the importance of studying and knowing the characteristics of the contaminated soil before selecting the CA. In the case of soils with high SOM content, humic and fulvic acids can act as CAs, increasing iron availability.

HAs can also be obtained from organic wastes. In this line, a diesel-contaminated soil collected in a former gasoline station was treated by the MF process using HAs extracted from compost [107]). A traditional stabilizer of hydrogen peroxide $\left(\mathrm{KH}_{2} \mathrm{PO}_{4}\right)$ was also used in this work. The authors observed a beneficial effect of extracted HAs in terms of diesel removal $\left(90 \%\right.$ of diesel elimination when using $\mathrm{KH}_{2} \mathrm{PO}_{4}$ together with the HAs extracted from compost vs $55 \%$ without any amendment) [107]).

Some studies concerning the application of MF process have been focused on the degradation of methyl tert-butyl ether (MtBE), a fuel additive. Without the addition of an external iron source, the effectiveness of a MF process was investigated by performing column tests on an artificially MtBE contaminated soil [87]. The obtained results showed that preconditioning soil with EDTA significantly enhanced MtBE oxidation. Moreover, no pollutant by-products were detected, suggesting that the tert-butyl group of MtBE was completely degraded [87]. This process was also successfully applied to the pilot-scale treatment of a site contaminated by MtBE, using hydrogen peroxide catalyzed by naturally occurring iron mineral, chelating agents (EDTA and SC) and hydrogen peroxide stabilizer 
(potassium hydrogen phosphate). The remediation process allowed to meet the clean-up goals in an area of $75 \mathrm{~m}^{2}$ [86].

Six iron compounds were tested as catalysts for the remediation of a diesel contaminated soil by MF (one of them, $\mathrm{Fe}(\mathrm{III})-\mathrm{NTA}$ ). In the presence of the $\mathrm{Fe}-\mathrm{CA}, 80 \%$ of pollutant removal was achieved after $1 \mathrm{~h}$ of reaction [164]. Gong et al. studied the application of a MF process, using $\mathrm{Fe}(\mathrm{III})$ /NTA in a molar ratio of 1:1 as a catalyst, coupled with a bioremediation treatment [165]. A TPHs conversion of $89 \%$ was obtained in the combined treatment (after bioremediation for 20 weeks) compared with $55 \%$ in the biological treatment alone without EDTA addition.

Additionally, as stated in the case of PAHs, some authors have studied the sequential addition of hydrogen peroxide (stepwise addition of $\mathrm{H}_{2} \mathrm{O}_{2}$ ), reporting that following this remediation strategy, the elimination of TPHs can considerably increase [72,74]. After the sequential addition of the oxidant, the three-time addition of $\mathrm{H}_{2} \mathrm{O}_{2}$ was the optimal dose considering treatment efficiency and economic aspects. In the presence of citrate, $\mathrm{Xu}$ et al. achieved a TPHs degradation of $51 \%$, which increased up to $93 \%$ after applying a biological treatment [74].

The remediation of these compounds has been recently studied, combining the MF process and bioremediation. For example, Guzmán-López et al. evaluated the degradation of TPHs from soil artificially contaminated with crude oil by MF with citrate as a CA followed by a biostimulation treatment (with nutrients and oil palm bagasse used as an amendment), obtaining exciting results [166]. 
Table 7. Research studies for TPHs degradation in soils using MF process.

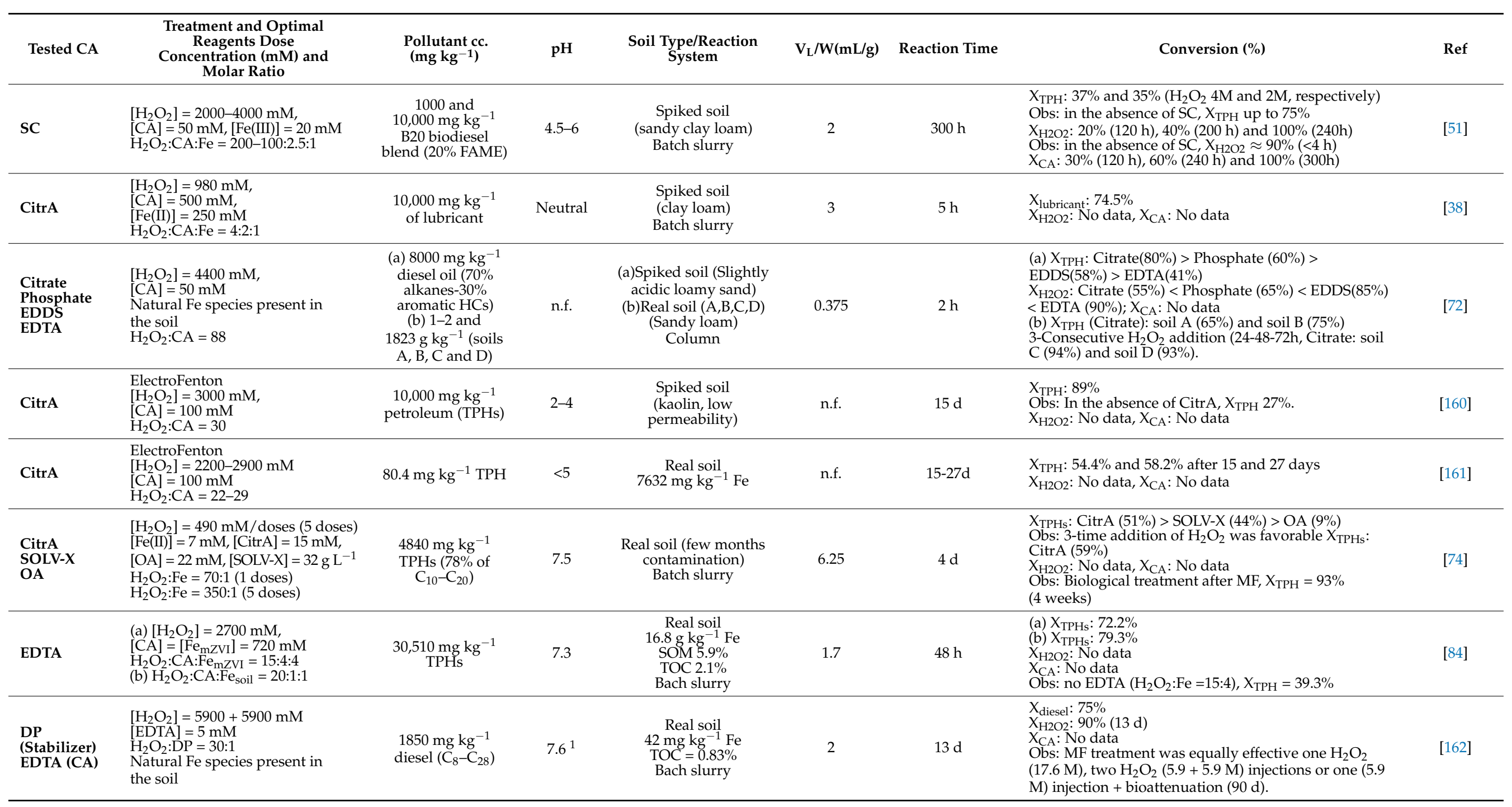


Table 7. Cont.

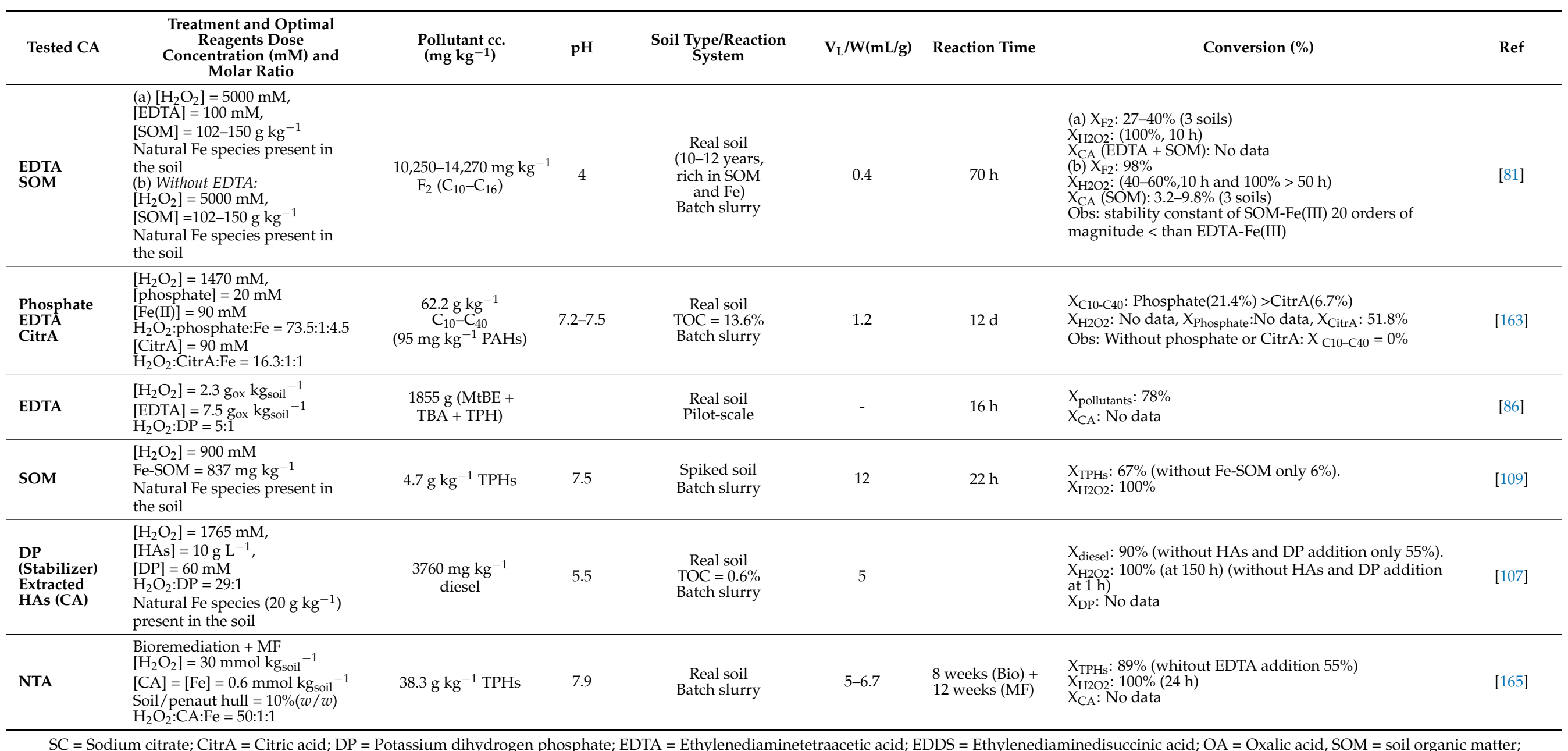

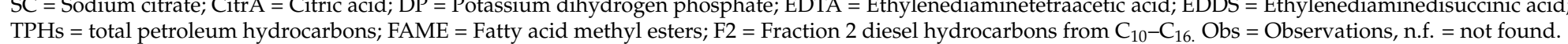




\subsubsection{Unsaturated Chlorinated Compounds and Pesticides}

Unsaturated chlorinated compounds are organic molecules with at least one multiple bond (double or triple) and at least one chlorine atom substituent. The more chlorine substituent on unsaturated carbon compounds decreases the reaction rate of the pollutant with $\mathrm{OH}^{\bullet}$, as can be seen in Table 4 .

Ko et al. used SC to enhance the oxidation of soil polluted with a non-aqueous phase liquid (NAPL) [167]. However, their results revealed that the application of SC with $\mathrm{H}_{2} \mathrm{O}_{2}$ did not improve the removal of the pollutants (chlorinated volatile organic compounds (CVOCs), among them, several chlorinated ethenes (tetrachloroethene (PCE), trichloroethene (TCE)) and ethanes (saturated compounds such as 1,1,2,2-tetrachloroethane (TeCA), 1,2-dichloroethane (DCA) and 1,1,2-trichloroethane (TCA)), as shown in Table 8) present in the groundwater. This result may be partially attributed to the high $\mathrm{pH}$ of the system $(\mathrm{pH}>8)$ and the scavenging of $\mathrm{OH}^{\bullet}$ by citrate. Although the rate constants of citrate and Fe-citrate with $\mathrm{OH}^{\bullet}$ are relatively low $\left(k_{\text {citrate, }} \mathrm{OH}^{\bullet}=5 \times 10^{7} \mathrm{M}^{-1} \mathrm{~s}^{-1}[126,127]\right.$ and $k_{\mathrm{Fe}-\text {-citrate, } \mathrm{OH}^{\bullet}}=1.2 \times 10^{8} \mathrm{M}^{-1} \mathrm{~s}^{-1}$ [70]) compared to the rate constant of the studied pollutants (chlorinated ethanes and ethenes) with $\mathrm{OH}^{\bullet}$ (in the order of $10^{9} \mathrm{M}^{-1} \mathrm{~s}^{-1}$, Table 4), the chelating agent scavenger effect cannot be assumed to be negligible due to the high concentration of citrate used in these experiments (approximately eight times higher than the pollutants).

Conversely, other authors have reported a significant increase in pollutant conversion (the pesticide diuron) using SC as a CA [135,143], as shown in Table 8. Vicente et al. reported an increase in the diuron conversion from $55 \%$ (without $\mathrm{SC}$ addition) to $80 \%$ (in the presence of this CA) [135]. These results can be explained attending, on the one hand, to the slightly higher reactivity of diuron with $\mathrm{OH}^{\bullet}$ radicals than the contaminants considered in the previous works (such as TCE and PCE [167]; $k_{\text {diuron, }} \mathrm{OH}^{\bullet}=4.8 \times 10^{9} \mathrm{M}^{-1} \mathrm{~s}^{-1}>k_{\mathrm{TCE}, \mathrm{OH}}{ }^{\bullet}=$ 3-4 $\times 10^{9} \mathrm{M}^{-1} \mathrm{~s}^{-1}>k_{\mathrm{PCE}, \mathrm{OH}}{ }^{\bullet}=2.8 \times 10^{9} \mathrm{M}^{-1} \mathrm{~s}^{-1}$ [126], Table 4). On the other hand, the concentration of SC may play a determining factor. Tan et al. reported a maximum of $80 \%$ of diuron degradation when the citrate:Fe ratio was 1:1 [168]. However, the degradation of diuron was only $57 \%$ when the citrate:Fe ratio was 5:1, which was even lower than the diuron degradation achieved without $\mathrm{CA}$ addition. This was because, as previously stated, when SC (the CA used in this case) is added in relatively high concentrations, it can compete with contaminant for $\mathrm{OH}^{\bullet}$. Moreover, in the presence of $\mathrm{CA}$ excess, the possible formation of plentiful hexa-coordinated complexes of iron hinders the accessibility of the iron center for hydrogen peroxide attachment [169], resulting in decreased degradation efficiency of the contaminant. In this way, as previously explained in the case of PAHs (Section 3.2.2), an optimal concentration of citrate should be high enough to favor the formation of the Fe-citrate complex (mainly due to its relatively low stability constant, Table 2) but not too high to cause an important scavenging effect on the hydroxyl radicals produced or to hinder the accessibility of the iron. Additionally, Ko et al. tested the addition of persulfate combined with hydrogen peroxide in a PS-MF system using citrate as CA. Regrettably, a lower removal of the CVOCs was achieved in this system, suggesting that citrate may scavenge hydroxyl radicals [167].

The use of pyrophosphate (SP) was a promising option for the remediation of soils polluted with polychlorinated biphenyls (PCBs) and PCE in the MF process $[54,56,59]$. Ma et al. reported that PCBs degradation followed the descending order with different CAs and the same reaction conditions: EDDHA $(63 \%)>\mathrm{SP}(62 \%)>\mathrm{SC}(33 \%)>$ EDDS $(18 \%)>$ GLDA (sodium N,N'-bis(carboxymethyl) glutamic acid) (1\%) [56]. A SP:Fe(II) molar ratio of 1:1 resulted in the highest removal rate of PCBs. The inhibitory effect of the CA was noticed when the SP concentration was too high, in this case, the complex $\mathrm{Fe}-\mathrm{SP}$ precipitated, decreasing the efficiency of the remediation treatment, which is in accordance with the results reported by Venny et al. in the remediation of other pollutants (PAHs, (the optimal SP:Fe molar ratio was 1:1) [55]. Moreover, the study carried out by Ma et al. revealed that not only inorganic CAs (SP), but also organic CAs such as EDDHA can markedly enhance the removal of PCBs from capacitor-oil-contaminated soil slurry [56]. 
In the last case, the soil $\mathrm{pH}$ dropped significantly from neutral values up to 2.7. The $\mathrm{pH}$ decrease can be due to the generation of important concentrations of organic acids as intermediate oxidation by-products from the incomplete oxidation of refractory pollutants. In the case of $\mathrm{Fe}(\mathrm{II}) / \mathrm{PPP} / \mathrm{H}_{2} \mathrm{O}_{2}$ system, the ROS mainly produced are hydroxyl radicals $(90 \%)$ (as schematized in Figure 2). In this way, hydroxide groups are generated in excess (Equation (14)) which are able to neutralize the acid compounds produced during the degradation of the pollutant. However, in the $\mathrm{Fe}(\mathrm{II}) / \mathrm{EDDHA} / \mathrm{H}_{2} \mathrm{O}_{2}$ system, insufficient hydroxyl groups were produced (Equation (14)) to balance the acids generated (both $\mathrm{OH}^{\bullet}$ and $\mathrm{O}_{2}{ }^{\bullet-}$ radicals are important (50\% of the ROS generated), as schematized in Figure 5), and, consequently, the $\mathrm{pH}$ of the reaction medium declined more in this system.

This is the only work found in the literature using EDDHA as CA to improve the Fenton process in soils remediation [56]. In this way, it would be of interest to investigate its potential use to remediate soils polluted with other types of contaminants or soil matrix. For example, if EDDHA was used for the in-situ remediation of calcareous soil, the buffer effect of the soil would probably prevent the $\mathrm{pH}$ drop produced by this CA. Moreover, there is limited information in the literature regarding the mechanism of this CA and the different rate constants involved in the process, and thus, more research is needed.

Therefore, based on the results obtained for this group of contaminants, an optimal order of use of the different CAs to obtain a higher removal of unsaturated chlorinated compounds and pesticides can be as follows (the optimal CA:Fe ratio reported has been included for each CA): Citratre (Citrate:Fe = 1:1) $>\mathrm{SP}(\mathrm{SP}: \mathrm{Fe}=1: 1)>$ EDDHA (0.5:1) $>$ EDTA $>$ EDDS $>$ GLDA. However, it should be considered that this order is only indicative. In this way, for each specific case, the rate constant of the contaminant with the $\mathrm{OH}^{\bullet}$ radicals generated (Table 4) and the scavenging effect of the CA (Table 3) should be considered, as well as the specific soil matrix characteristics. 
Table 8. Research studies for unsaturated chlorinated compounds degradation in soils using MF process.

\begin{tabular}{|c|c|c|c|c|c|c|c|c|}
\hline Tested CA & $\begin{array}{l}\text { Treatment and Optimal } \\
\text { Reagents Dose } \\
\text { Concentration (mM) and } \\
\text { Molar Ratio }\end{array}$ & $\begin{array}{l}\text { Pollutant cc. } \\
\left(\mathrm{mg} \mathrm{kg}^{-1}\right)\end{array}$ & $\mathrm{pH}$ & $\begin{array}{c}\text { Soil Type/Reaction } \\
\text { System }\end{array}$ & $\mathrm{V}_{\mathrm{L}} / \mathrm{W}(\mathrm{mL} / \mathrm{g})$ & Reaction Time & Conversion (\%) & Ref \\
\hline SC & $\begin{array}{l}\text { (a) }\left[\mathrm{H}_{2} \mathrm{O}_{2}\right]=880 \mathrm{mM}, \\
{[\mathrm{CA}]=5.2 \mathrm{mM} \text {, }} \\
\mathrm{H}_{2} \mathrm{O}_{2}: \mathrm{L}=170: 1 \\
\text { Natural Fe species present in } \\
\text { the soil } \\
\\
\text { (b) }\left[\mathrm{H}_{2} \mathrm{O}_{2}\right]=880 \mathrm{mM}, \\
{[\mathrm{CA}]=[\mathrm{Fe}(\mathrm{III})]=5.2} \\
\mathrm{mMH}_{2} \mathrm{O}_{2}: \mathrm{CA}: \mathrm{Fe}=170: 1: 1\end{array}$ & $40 \mathrm{mg} \mathrm{kg}^{-1}$ diuron & $4.5-6$ & $\begin{array}{l}\text { Spiked soil } \\
\text { (sandy clay loam, } \\
18.2 \mathrm{mg} \mathrm{kg}^{-1} \mathrm{Fe} \text { ) } \\
\text { Batch slurry }\end{array}$ & 2 & $48 \mathrm{~h}$ & $\begin{array}{l}\text { (a) } \mathrm{X}_{\text {diuron }}: 73 \% \\
\mathrm{X}_{\mathrm{H} 2 \mathrm{O} 2}: 50 \% \\
\mathrm{X}_{\mathrm{C}}: 40 \% \\
\text { (b) } \mathrm{X}_{\text {diuron }}: 80 \% \\
\mathrm{X}_{\mathrm{H} 2 \mathrm{O} 2}: 65 \% \\
\mathrm{X}_{\mathrm{Cb}}: 100 \% \\
\text { Ob: } \mathrm{X}_{\text {diuron }}=55 \%, \mathrm{X}_{\mathrm{H} 2 \mathrm{O} 2}=40 \% \text { without } \mathrm{SC} \text { or } \\
\text { Fe addition. }\end{array}$ & [135] \\
\hline SC & $\begin{array}{l}{\left[\mathrm{H}_{2} \mathrm{O}_{2}\right]=294 \mathrm{mM},[\mathrm{CA}]=50 \mathrm{mM},} \\
{[\mathrm{Fe}(\mathrm{II})]=5 \mathrm{mMH}_{2} \mathrm{O}_{2}: \mathrm{CA}: \mathrm{Fe}=} \\
58.8: 10: 1\end{array}$ & $39 \mathrm{mg} \mathrm{kg}^{-1}$ diuron & Neutral & $\begin{array}{c}\text { Spiked soil } \\
\text { (sandy clay loam, } \\
8.3 \mathrm{mg} \mathrm{kg}^{-1} \mathrm{Fe} \text { ) } \\
\text { Batch slurry }\end{array}$ & 2 & $48 \mathrm{~h}$ & $\begin{array}{l}\mathrm{X}_{\text {diuron }}: 90 \% \\
\mathrm{X}_{\mathrm{H} 2 \mathrm{O} 2}: 100 \% \\
\mathrm{X}_{\mathrm{CA}}: 20 \%\end{array}$ & [143] \\
\hline SC & $\begin{array}{l}\text { (a) Fenton } \\
{\left[\mathrm{H}_{2} \mathrm{O}_{2}\right]=441 \mathrm{mM},} \\
{[\mathrm{CA}]=136 \mathrm{mM},[\mathrm{Fe}(\mathrm{II})]=45 \mathrm{mM}} \\
\mathrm{H}_{2} \mathrm{O}_{2}: \mathrm{CA}: \mathrm{Fe}=9.3: 3: 1 \\
\\
\\
\text { (b) } \mathrm{H}_{2} \mathrm{O}_{2}+P S \\
{\left[\mathrm{H}_{2} \mathrm{O}_{2}\right]=147 \mathrm{mM},[\mathrm{PS}]=63 \mathrm{mM},} \\
{[\mathrm{CA}]=68 \mathrm{mM}} \\
{[\mathrm{Fe}]=0 \mathrm{mM}} \\
\mathrm{H}_{2} \mathrm{O}_{2}: \mathrm{PS}: \mathrm{CA}=2.2: 1: 1\end{array}$ & $\begin{array}{l}1228 \mathrm{mg} \mathrm{kg} \mathrm{kg}^{-1} \\
\text { NAPL: } 30 \% \text { of } \\
\text { 5 CVOCs (DCA, } \\
\text { TCE, TCA, PCE, } \\
\text { and TeCA) and } \\
\text { 70\% chlorinated } \\
\text { aliphatic organics, } \\
\text { chlorinated } \\
\text { aromatics, BTEX, } \\
\text { styrene and TPH. }\end{array}$ & 8.1 & $\begin{array}{l}\text { Spiked soil } \\
\text { Batch slurry }\end{array}$ & 1.9 & $48 \mathrm{~h}$ & 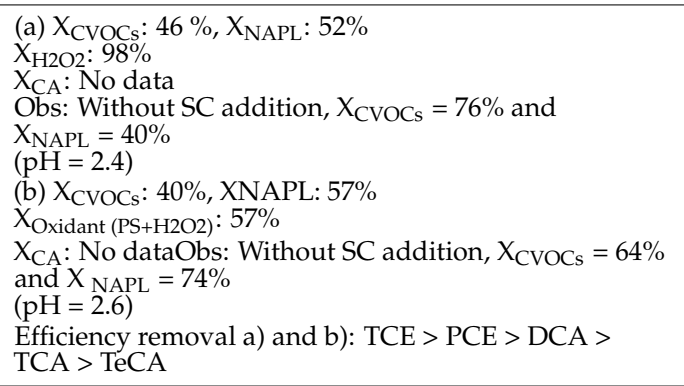 & [167] \\
\hline SP & $\begin{array}{l}{\left[\mathrm{H}_{2} \mathrm{O}_{2}\right]=250 \mathrm{mM}} \\
{[\mathrm{CA}]=[\mathrm{Fe}(\mathrm{III})]=25 \mathrm{mM}} \\
\mathrm{H}_{2} \mathrm{O}_{2}: \mathrm{CA}: \mathrm{Fe}=10: 1: 1\end{array}$ & $\begin{array}{l}80 \mathrm{mg} \mathrm{kg}^{-1} \text { of } \\
\text { PCBs for RS, PS, } \\
\text { and FS, and } \\
70.67 \mathrm{mg} \mathrm{kg}^{-1} \text { of } \\
\text { PCBs for BS }\end{array}$ & 7 & $\begin{array}{l}\text { Spiked, } 4 \text { soils: RS, PS, } \\
\text { FS, BS. } \\
\text { Batch slurry }\end{array}$ & 20 & $24 \mathrm{~h}$ & $\begin{array}{l}\mathrm{X}_{\mathrm{PCBS}}: \mathrm{RS}(91.3 \%)>\mathrm{BS}(81.3 \%) \approx \mathrm{PS}(81.0 \%)>\mathrm{FS}(77.6 \%) \\
\mathrm{X}_{\mathrm{H} 2 \mathrm{O} 2}(8 \mathrm{~h}): \mathrm{FS}(97 \%)>\mathrm{PS}(93 \%)>\mathrm{BS}(87 \%)>\mathrm{RS}(78 \%) \\
\mathrm{X}_{\mathrm{L}} \text { (hydrolysis) }(8 \mathrm{~h}): \mathrm{RS}(14 \%)>\mathrm{FS}(13 \%)>\mathrm{PS}(8 \%)> \\
\text { BS (6.5\%) } \\
\text { Obs: production of } \mathrm{OH}^{\bullet}(\mathrm{RS}>\mathrm{BS}>\mathrm{PS}>\mathrm{FS})\end{array}$ & [59] \\
\hline $\begin{array}{l}\text { SP } \\
\text { GA } \\
\text { PA }\end{array}$ & $\begin{array}{l}{\left[\mathrm{H}_{2} \mathrm{O}_{2}\right]=146 \mathrm{mM},} \\
{[\mathrm{F}(\mathrm{III}]=10 \mathrm{mM},[\mathrm{SP}]=20 \mathrm{mM}} \\
\mathrm{H}_{2} \mathrm{O}_{2}: \mathrm{CA}: \mathrm{Fe}=14.6: 2: 1\end{array}$ & $8109 \mathrm{mg} \mathrm{kg}^{-1} \mathrm{PCE}$ & $6-5.2$ & $\begin{array}{l}\text { Spiked (2 sandy soils) } \\
\text { Batch slurry }\end{array}$ & 5 & $120 \mathrm{~h}$ & $\begin{array}{l}\mathrm{X}_{\mathrm{PCE}}: \mathrm{SP}(18 \%), \mathrm{GA} \text { and PA (no data) } \\
\mathrm{X}_{\mathrm{H} 2 \mathrm{O} 2} \text { : No data, } \mathrm{X}_{\mathrm{CA}} \text { : No data } \\
\text { Obs: } \mathrm{X}_{\mathrm{PCE}}=0 \% \text { without SP addition } \\
\mathrm{Cl}^{-} \text {released }(\mathrm{mmol}): \mathrm{SP}(2.75)>\mathrm{PA}(2)>\mathrm{GA}(1.5) \\
\mathrm{Fe}\left(\mathrm{mg} \mathrm{L}^{-1}\right): 30 \mathrm{mM} \mathrm{SP}(125)>20 \mathrm{mM} \mathrm{SP}(50)>10 \mathrm{mM} \\
\mathrm{SP}(25)>\text { without } \mathrm{SP}(0)\end{array}$ & {$[54]$} \\
\hline
\end{tabular}


Table 8. Cont.

\begin{tabular}{|c|c|c|c|c|c|c|c|c|}
\hline Tested CA & $\begin{array}{c}\text { Treatment and Optimal } \\
\text { Reagents Dose } \\
\text { Concentration (mM) and } \\
\text { Molar Ratio }\end{array}$ & $\begin{array}{l}\text { Pollutant cc. } \\
\left.\text { (mg kg }{ }^{-1}\right)\end{array}$ & $\mathrm{pH}$ & $\begin{array}{c}\text { Soil Type/Reaction } \\
\text { System }\end{array}$ & $\mathrm{V}_{\mathrm{L}} / \mathrm{W}(\mathrm{mL} / \mathrm{g})$ & Reaction Time & Conversion (\%) & Ref \\
\hline $\begin{array}{l}\text { SP } \\
\text { EDDS } \\
\text { SC } \\
\text { GLDA } \\
\text { EDDHA }\end{array}$ & $\begin{array}{l}\text { (a) } \mathrm{CA} \text { screening } \\
{\left[\mathrm{H}_{2} \mathrm{O}_{2}\right]=500 \mathrm{mM},[\mathrm{CA}]=25 \mathrm{mM}} \\
{[\mathrm{Fe}(\mathrm{III}]=50 \mathrm{mM}} \\
\mathrm{H}_{2} \mathrm{O}_{2}: \mathrm{CA}: \mathrm{Fe}=10: 1: 2 \\
\text { (b) Optimal } \\
{\left[\mathrm{H}_{2} \mathrm{O}_{2}\right]=1000 \mathrm{mM},} \\
{[\mathrm{EDDHA}]=25 \mathrm{mM},} \\
{[\mathrm{SP}]=[\mathrm{Fe}(\mathrm{II})]=50 \mathrm{mM}} \\
\mathrm{H}_{2} \mathrm{O}_{2}: \mathrm{SP}: \mathrm{Fe}=20: 1: 1 \\
\mathrm{H}_{2} \mathrm{O}_{2}: \mathrm{EDDHA}: \mathrm{Fe}=20: 0.5: 1\end{array}$ & $63.9 \mathrm{mg} \mathrm{kg}^{-1}$ РCB & $\begin{array}{c}6.6 \\
(\mathrm{SP}) \\
2.7(\mathrm{ED}- \\
\mathrm{DHA})\end{array}$ & $\begin{array}{c}\text { Real } \\
\text { (sandy soil) } \\
\text { (4465 and } 812 \mathrm{mg} \mathrm{kg}{ }^{-1} \\
\text { Fe and Ca, } \\
\text { respectively) } \\
\text { Batch slurry }\end{array}$ & 20 & $\begin{array}{l}\text { (a) } 24 \mathrm{~h} \\
\text { (b) } 48 \mathrm{~h}\end{array}$ & $\begin{array}{l}\text { (a) } \mathrm{X}_{\mathrm{PCB}}: \mathrm{EDDHA}(63 \%)>\mathrm{SP}(62 \%)>\mathrm{XSC}(33 \%)> \\
\mathrm{EDDS}(18 \%)>\mathrm{GLDA}(1 \%) \\
\text { Obs: Optimum SP:Fe = } 1: 1, \mathrm{X}_{\mathrm{PCB}}=75 \% \\
\mathrm{X}_{\mathrm{PCB}} \text { removal higher in Fe(II) system than that in the } \\
\mathrm{Fe}(\mathrm{III}) \text { system. } \\
\mathrm{X}_{\mathrm{H} 2 \mathrm{O} 2} \text { : No data, } \mathrm{X}_{\mathrm{CA}} \text { : No data } \\
\text { (b) } \mathrm{X}_{\mathrm{PCB}}: \mathrm{SP}(87.5 \%)>\mathrm{EDDHA}(77.1 \%) \\
\mathrm{X}_{\mathrm{PCB}}: 53 \% \text { without } \mathrm{SP} / \mathrm{EDDHA}(15 \mathrm{~min}) \\
\mathrm{X}_{\mathrm{H} 2 \mathrm{O} 2}(10 \mathrm{~min}) \text { : without SP } / \mathrm{EDDHA}(99 \%)>\text { EDDHA } \\
\text { (39\%) > SP (37\%) } \\
\mathrm{X}_{\mathrm{CA}}: \text { No data }\end{array}$ & {$[56]$} \\
\hline
\end{tabular}

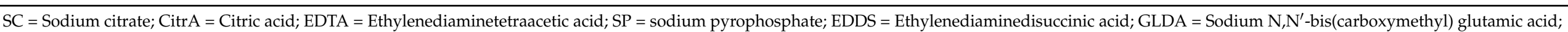

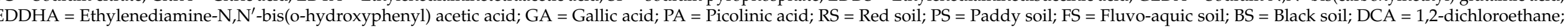

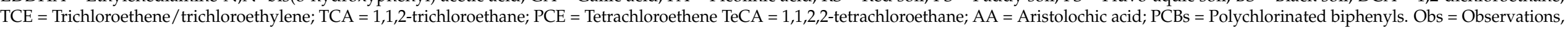
n.f. $=$ not found. 


\subsubsection{Saturated Chlorinated Compounds}

Saturated chlorinated compounds are organic molecules with single bonds and at least one chlorine atom substituent. The use of CAs to enhance the remediation of saturated chlorinated contaminated soils has been very scarcely studied in the literature.

In the case of chlorinated ethane compounds, it has been demonstrated that the higher the number of chlorine substituents on the ethane molecule, the more difficult it is the pollutant to oxidize: tetrachloroethane (TeCA) (4) < trichloroethane (TCA) (3) < dichloroethane (DCA) (2) [167], which is related to the rate constants of these compounds with hydroxyl radicals. In this way, depending on the type of unsaturated chlorinated compound, different CAs should be selected. As previously stated, Ko et al. performed a comparative study on oxidative treatments (Fenton, PS, and MF) of chlorinated ethanes and ethenes. The CA selected in the mentioned study was SC [167]. Regardless of the oxidation treatment, the ethane's degradation was always lower than the corresponding to ethenes, highlighting the high refractoriness of these pollutants. Furthermore, these authors found that the addition of citrate kept post-treatment $\mathrm{pH}$ near neutral values. However, the use of $\mathrm{SC}$ resulted inefficient due to the hydroxyl radicals scavenging effect of this CA [167].

Dominguez et al. reported that the application of the Fenton process was unappropriated for the elimination of hexachlorocyclohexanes $(\mathrm{HCHs})$ from a real polluted soil with a high concentration of carbonates $(>40 \%)$. Carbonates (and bicarbonates) acted as a buffer, maintaining the $\mathrm{pH}$ of the system at around neutrality, and at these conditions, the catalyst precipitated in the form of $\mathrm{Fe}(\mathrm{OH})_{3}$, and it was rapidly removed from the reaction medium [36]. Moreover, $\mathrm{H}_{2} \mathrm{O}_{2}$ was quickly decomposed because of unproductive reactions. The concentration of iron in this real soil was high, and to increase the concentration of iron available at neutral $\mathrm{pH}$, these authors tested SC $(10 \mathrm{mM})$. However, a negligible concentration of iron was found to be available at these conditions $\left(<2 \mathrm{mg} \mathrm{L}^{-1}\right.$ after $\left.24 \mathrm{~h}\right)$, highlighting the need of adding the catalyst externally.

On the other hand, it should be considered that the rate constant of lindane (one of the $\mathrm{HCHs}$ isomer, g- $\mathrm{HCH}$ ) with the hydroxyl radicals is relatively low $\left(k_{\mathrm{HCH}}\right.$ (lindane), $\mathrm{OH}^{\bullet}=$ $5.8 \times 10^{8} \mathrm{M}^{-1} \mathrm{~s}^{-1}$ [148]) compared to the values reported for other organic pollutants (Table 4). For this reason, the application of the Fenton process for the remediation of soils contaminated with saturated chlorinated compounds requires further research to find a feasible CA able to keep the iron available at neutral $\mathrm{pH}$ and achieve an acceptable hydrogen peroxide stabilization. For example, among the organic CAs considered in this review, the low scavenging effect on $\mathrm{OH}^{\bullet}$ of oxalic acid (Table 3) might be interesting for its application in the oxidation of these recalcitrant organic contaminants (HCHs). However, the addition of $\mathrm{OA}$ might decrease the reaction $\mathrm{pH}$ due to the relatively low $p K a$ value of this compound, and a detailed study of the soil type must be carried out before the selection of the CA. In this way, inorganic CAs (such as SP) could also be tested to enhance the degradation of these pollutants by the Fenton process, considering the advantages of these CAs over the organic ones. Firstly, Fe- $\mathrm{L}_{\text {inorganic }}$ complexes have lower reaction rates with hydroxyl radicals than Fe- $\mathrm{L}_{\text {organic }}$ (Table 3 ) and, therefore, they will compete less for the generated radical species, which can be of great interest for the remediation of such refractory compounds. Secondly, inorganic CAs are generally nontoxic and stable, unlike many organic ligands.

\section{Potential Chelating Agents for Soil Remediation by Fenton Process}

In previous sections, the main chelating agents used to eliminate contaminants in soils have been described. As earlier mentioned, the organic CAs can significantly scavenge the radical species produced in the system, lowering their availability to further oxidize the recalcitrant organic compounds, resulting in lower contaminant conversion. Consequently, the continuous supply of oxidant and CA to the reaction medium is required. Furthermore, some of the organic CAs studied also pose secondary environmental risks. Thus, the use of inorganic CAs (apart from the commonly used pyrophosphate) may provide a promising alternative approach for extending the $\mathrm{pH}$ range of the Fenton system to neutral values. 
Considering the above, some CAs that have been successfully used in the aqueous phase are exposed as potential CAs for soil application.

\subsection{Polyoxometalate}

Considering the above, polyoxometalates (POMs), such as $\mathrm{PW}_{12} \mathrm{O}_{4} 0^{3-}$ and $\mathrm{SiW}_{12} \mathrm{O}_{40}{ }^{4-}$, are inorganic CAs that form soluble complexes with $\mathrm{Fe}(\mathrm{III})$ under neutral $\mathrm{pH}$ conditions [170]. POM is biodegradable, non-toxic, and resistant to oxidation. Thus, its use presents significant advantages over most organic CAs [41]. Some reports involving the use of POM in the Fenton process in aqueous solution have been published with exciting results [170-174]. For example, Lee et al. [170] found that $\mathrm{PW}_{12} \mathrm{O}_{40}{ }^{3-}$ in the homogeneous $\mathrm{Fe}(\mathrm{III}) / \mathrm{H}_{2} \mathrm{O}_{2}$ system significantly enhanced the oxidation of recalcitrant organic compounds even at $\mathrm{pH}$ values of 8.5. These authors suggested that coordination of POM with iron converted the active oxidant from $\mathrm{Fe}(\mathrm{IV})$ to hydroxyl radical at circumneutral $\mathrm{pH}$ values. Lee et al. [174] reported that the presence of POM in the zerovalent iron (ZVI) $/ \mathrm{H}_{2} \mathrm{O}_{2}$ system enhanced the efficiency of 12 organic contaminants abatement and oxidant utilization under circumneutral $\mathrm{pH}$ values. In the mechanism proposed by Lee et al. [170], the catalyst forms complexes with POM, preventing its precipitation on the ZVI surface or in bulk solution and, therefore, enhancing the Fenton process. Regrettably, the reaction mechanism of organic contaminant degradation in the $\mathrm{Fe}(\mathrm{III}) / \mathrm{POM} / \mathrm{H}_{2} \mathrm{O}_{2}$ system and the nature of the reactive radicals produced are not fully understood, and much work is still needed. It should be considered that POM anion in the aqueous phase gradually hydrolyses at neutral and alkaline $\mathrm{pH}$ values (making difficult its recovery from the medium after the reaction) $[170,171]$. Nevertheless, the POM-Fe complex is relatively more stable [170]. In this line, heterogeneous catalysts such as ZVI and other iron-containing materials are catching the attention of researchers for the treatment of polluted waters. However, no reports regarding the remediation of soils contaminated with organic pollutants using the relatively new $\mathrm{POM} / \mathrm{H}_{2} \mathrm{O}_{2}$ system have been found. In this way, further research to develop more stable forms of iron-polyoxometalate catalysts or less expensive ways of producing POM is required [170].

\subsection{Tripolyphosphate}

Tripolyphosphate (TPP), one of the commonly used polyphosphates, had proved to be a promising inorganic CA for iron stabilization in Fe-based AOPs for the abatement of organics pollutants in aqueous systems $[175,176]$. Deng et al. studied the treatment of coking wastewater (containing phenols, PAHs, pyridine, and indole) in a novel electroFenton (EF) process at $\mathrm{pH}=6.8$ by using TPP [176]. Their results showed that total organic carbon (TOC) decay in the presence of TPP was 2.1 times higher than that of conventional EF. As for PPP and POM, this CA has no scavenging ability [61]. Nevertheless, this compound has been scarcely used to remediate polluted soils.

\subsection{Other Organics CAs}

Apart from those mentioned above, other organics CAs not considered in the review have shown promising results in removing organics pollutants from the aqueous phase, and they could be tested for soil remediation. Some of them are aspartic acid and glutamic acid [177]. The formation of Fe(II)-aspartate and Fe(II)-glutamate complexes has been proved to extend and improve the rate of $\mathrm{p}$-nitrophenol degradation process to neutral $\mathrm{pH}$ conditions. The very fast removal (minutes) of this pollutant makes the application of these CAs a promising way to enhance the Fenton process [177]. Moreover, polyacrylic acids (PAAs) have been proven to be efficient CAs due to their multiple binding sites [178]. Applying the CAs mentioned above for the remediation of polluted soils has not been carried out to the best of our knowledge, and further research is needed. 


\section{Conclusions}

The addition of chelating agents (CAs) allows overcoming some of the main limitations of conventional Fenton in soil remediation, such as the possibility to operate at circumneutral $\mathrm{pH}$, maintaining the catalyst $(\mathrm{Fe})$ available and increasing the oxidant $\left(\mathrm{H}_{2} \mathrm{O}_{2}\right)$ stability. CAs, forming complexes with Fe, allow extending conventional Fenton $\mathrm{pH}$ to neutral or near-neutral $\mathrm{pH}$. The selection of the $\mathrm{CA}$ is not trivial and several aspects should be considered, such as the pollutant type and its accessibility, the characteristics of the soil matrix (SOM and TOC content, presence of natural iron oxides and other metals, carbonates, etc.), and the future use of the soil, among others. This paper systemically reviewed the application of chelate-modified Fenton (MF) systems using inorganic (pyrophosphate) and organic (polycarboxylic acids, aminopolycarboxylic acids and humic substances) CAs in the remediation of soils contaminated with organics compounds (BTEX, phenolic compounds, PAHs, TPHs, saturated and unsaturated chlorinated compounds and pesticides). The main conclusions are as follows:

- More than $50 \%$ of the papers found in the literature focused on the treatment of artificially contaminated soils (spiked soils). However, the results obtained with these soils cannot be directly extrapolated to real soils. Moreover, most of them have been carried out batch-wise. Therefore, for future research, the remediation of real polluted soils would be recommended, and for more realistic conditions (dynamic conditions), column experiments would be preferred.

- Many factors affect the efficiency of the MF process, including the type of the CA, the molar ratio $\mathrm{CA}: \mathrm{Fe}$, the $\mathrm{H}_{2} \mathrm{O}_{2}$ dose, the reagents dosing mode, the reactivity of $\mathrm{CA}$ and Fe-CA for the reactive radical species generated, the $\mathrm{pH}$, the soil matrix characteristics, the pollutant ageing, and accessibility, etc.

- Other factors, such as the adsorption of CAs onto the soil (which is usually nonnegligible) have been scarcely studied in the literature. In this way, further attempts to study the application of CAs to enhance the Fenton process in soil remediation should not be based solely on the degradation of the pollutant. Additionally, they should include a detailed study of the interaction of the CA and Fe-L complexes with soil and soil constituents and its diminution from the solution related to possible degradation or adsorption mechanisms.

- Inorganic CAs are generally nontoxic and non-reactive with the radical species generated, and therefore, present significant advantages over the organic CAs.

- The system $\mathrm{pH}$ and $\mathrm{CA}: \mathrm{Fe}$ molar ratio affect the nature and amount of the reactive oxygen species ( $\mathrm{ROS}: \mathrm{OH}^{\bullet}, \mathrm{O}_{2}{ }^{\bullet-}, \mathrm{HO}_{2} \bullet, \mathrm{Fe}(\mathrm{IV}),(\mathrm{FeO})^{2+}$ ) generated in the MF process.

- $\quad$ For most of the CAs reviewed, Fe(III)-L is reduced to Fe(II)-L by superoxide radicals and not by the direct reaction with $\mathrm{H}_{2} \mathrm{O}_{2}$. However, some contradictory results have been found in the literature regarding the MF mechanism and further research is needed.

- The evolution of $\mathrm{CA}, \mathrm{H}_{2} \mathrm{O}_{2}$ and catalyst during the reaction time in the MF system is a critical factor determining the pollutant removal and, therefore, should be systematically evaluated. Nevertheless, it has been scarcely considered in the literature and requires further research. Thus, future papers should include experimental measurement of chemical evolution in the system (soil and aqueous phases) and calculate time-dependent kinetic rate coefficients for each reaction.

- Additional research studies are required to determine the optimum molar ratios of CA:Fe and Fe: $\mathrm{H}_{2} \mathrm{O}_{2}$ in the MF system as there is no agreement among researchers. In the case of inorganic CAs such as PPP, when a high CA:Fe molar ratio is used, steric hindrance is produced, inhibiting the Fenton catalytic cycle. Therefore, the use of a low CA:Fe molar ratio is recommended. However, when using CAs with low stability constants (as CitrA and OA), high CA:Fe molar ratios are needed.

- The radical scavenging effect of CA (and the corresponding Fe-L complex) is decisive. Therefore, to achieve an efficient pollutant degradation, the kinetic constant of the 
pollutant with $\mathrm{OH}^{\bullet}$ should be significantly higher than the kinetic constant of CA (and $\mathrm{Fe}-\mathrm{L}$ ) with these radicals.

- The application of CAs that have been successfully used in the aqueous phase, such as polyoxometalate, tripolyphosphate (inorganic CAs) or polyacrylic acids, and aspartic and glutamic acids (organic CAs), should be tested in soil remediation.

- Engineering cost studies for applying bench-scale laboratory experiments to field conditions are missing in the bibliography, and consequently should be included in future investigations.

Author Contributions: Conceptualization, A.C.-F., A.S., and C.M.D.; validation, A.S. and C.M.D.; writing—original draft preparation, A.C.-F.; writing—review and editing, A.C.-F. and C.M.D.; supervision, A.S. and A.R.; project administration, A.S. and A.R.; funding acquisition, A.S. and A.R. All authors have read and agreed to the published version of the manuscript.

Funding: The authors acknowledge the financial support from the Regional Government of Madrid, through the CARESOIL project (S2018/EMT-4317) and by the Spanish Ministry of Science (project PID2019-105934RB-I00).

Data Availability Statement: Data is contained within the article.

Conflicts of Interest: The authors declare no conflict of interest.

\section{References}

1. TTeng, Y.; Wu, J.; Lu, S.; Wang, Y.; Jiao, X.; Song, L. Soil and soil environmental quality monitoring in China: A review. Environ. Int. 2014, 69, 177-199. [CrossRef]

2. Chen, F.; Li, X.; Ma, J.; Qu, J.; Yang, Y.; Zhang, S. Remediation of soil co-contaminated with decabromodiphenyl ether (BDE-209) and copper by enhanced electrokinetics-persulfate process. J. Hazard. Mater. 2019, 369, 448-455. [CrossRef]

3. Song, B.; Zeng, G.; Gong, J.; Liang, J.; Xu, P.; Liu, Z.; Zhang, Y.; Zhang, C.; Cheng, M.; Liu, Y.; et al. Evaluation methods for assessing effectiveness of in situ remediation of soil and sediment contaminated with organic pollutants and heavy metals. Environ. Int. 2017, 105, 43-55. [CrossRef]

4. Megharaj, M.; Ramakrishnan, B.; Venkateswarlu, K.; Sethunathan, N.; Naidu, R. Bioremediation approaches for organic pollutants: A critical perspective. Environ. Int. 2011, 37, 1362-1375. [CrossRef]

5. Chen, R.; Ye, C. Resolving soil pollution in China. Nat. Cell Biol. 2014, 505, 483. [CrossRef]

6. He, Z.; Shentu, J.; Yang, X.; Baligar, V.C.; Zhang, T.; Stoffella, P.J. Heavy metal contamination of soils: Sources, indicators and assessment. J. Environ. Indic. 2015, 9, 17-18.

7. Cheng, M.; Zeng, G.; Huang, D.; Lai, C.; Xu, P.; Zhang, C.; Liu, Y. Hydroxyl radicals based advanced oxidation processes (AOPs) for remediation of soils contaminated with organic compounds: A review. Chem. Eng. J. 2016, 284, 582-598. [CrossRef]

8. Zhou, Z.; Liu, X.; Sun, K.; Lin, C.; Ma, J.; He, M.; Ouyang, W. Persulfate-based advanced oxidation processes (AOPs) for organic-contaminated soil remediation: A review. Chem. Eng. J. 2019, 372, 836-851. [CrossRef]

9. Zhang, T.; Liu, Y.; Zhong, S.; Zhang, L. AOPs-based remediation of petroleum hydrocarbons-contaminated soils: Efficiency, influencing factors and environmental impacts. Chemosphere 2020, 246, 125726. [CrossRef] [PubMed]

10. Neyens, E.; Baeyens, J. A review of classic Fenton's peroxidation as an advanced oxidation technique. J. Hazard. Mater. 2003, 98, 33-50. [CrossRef]

11. Munoz, M.; De Pedro, Z.M.; Pliego, G.; Casas, J.A.; Rodriguez, J.J.; Garcia, M.M. Chlorinated Byproducts from the Fenton-like Oxidation of Polychlorinated Phenols. Ind. Eng. Chem. Res. 2012, 51, 13092-13099. [CrossRef]

12. Munoz, M.; DE Pedro, Z.M.; Casas, J.A.; Rodriguez, J.J. Preparation of magnetite-based catalysts and their application in heterogeneous Fenton oxidation-A review. Appl. Catal. B Environ. 2015, 176-177, 249-265. [CrossRef]

13. Lorenzo, D.; Santos, A.; Sánchez-Yepes, A.; Conte, L. Óscar; Domínguez, C.M. Abatement of 1,2,4-Trichlorobencene by Wet Peroxide Oxidation Catalysed by Goethite and Enhanced by Visible LED Light at Neutral pH. Catalysts 2021, 11, 139. [CrossRef]

14. Lorenzo, D.; Dominguez, C.M.; Romero, A.; Santos, A. Wet Peroxide Oxidation of Chlorobenzenes Catalyzed by Goethite and Promoted by Hydroxylamine. Catalysts 2019, 9, 553. [CrossRef]

15. Domínguez, C.M.; Ocón, P.; Quintanilla, A.; Casas, J.A.; Rodriguez, J.J. Highly efficient application of activated carbon as catalyst for wet peroxide oxidation. Appl. Catal. B Environ. 2013, 140-141, 663-670. [CrossRef]

16. Domínguez, C.M.; Ocón, P.; Quintanilla, A.; Casas, J.A.; Rodriguez, J.J. Graphite and carbon black materials as catalysts for wet peroxide oxidation. Appl. Catal. B Environ. 2014, 144, 599-606. [CrossRef]

17. Gan, S.; Ng, H.K. Modified Fenton oxidation of polycyclic aromatic hydrocarbon (PAH)-contaminated soils and the potential of bioremediation as post-treatment. Sci. Total Environ. 2012, 419, 240-249. [CrossRef]

18. Usman, M.; Tascone, O.; Faure, P.; Hanna, K. Chemical oxidation of hexachlorocyclohexanes (HCHs) in contaminated soils. Sci. Total Environ. 2014, 476-477, 434-439. [CrossRef] [PubMed] 
19. Pignatello, J.J.; Oliveros, E.; Mackay, A. Advanced Oxidation Processes for Organic Contaminant Destruction Based on the Fenton Reaction and Related Chemistry. Crit. Rev. Environ. Sci. Technol. 2006, 36, 1-84. [CrossRef]

20. Walling, C.; Goosen, A. Mechanism of the ferric ion catalyzed decomposition of hydrogen peroxide. Effect of organic substrates. J. Am. Chem. Soc. 1973, 95, 2987-2991. [CrossRef]

21. Babuponnusami, A.; Muthukumar, K. A review on Fenton and improvements to the Fenton process for wastewater treatment. J. Environ. Chem. Eng. 2014, 2, 557-572. [CrossRef]

22. Jung, Y.S.; Lim, W.T.; Park, J.; Kim, Y. Effect of pH on Fenton and Fenton-like oxidation. Environ. Technol. 2009, 30, 183-190. [CrossRef] [PubMed]

23. Bautista, P.; Mohedano, A.F.; Casas, J.A.; Zazo, J.A.; Rodriguez, J.J. An overview of the application of Fenton oxidation to industrial wastewaters treatment. J. Chem. Technol. Biotechnol. 2008, 83, 1323-1338. [CrossRef]

24. Sychev, A.Y.; Isak, V.G. Iron compounds and the mechanisms of the homogeneous catalysis of the activation of $\mathrm{O}_{2}$ and $\mathrm{H}_{2} \mathrm{O}_{2}$ and of the oxidation of organic substrates. Russ. Chem. Rev. 1995, 64, 1105-1129. [CrossRef]

25. Miller, C.J.; Rose, A.L.; Waite, T.D. Importance of Iron Complexation for Fenton-Mediated Hydroxyl Radical Production at Circumneutral pH. Front. Mar. Sci. 2016, 3, 134. [CrossRef]

26. Zhang, Y.; Klamerth, N.; El-Din, M.G. Degradation of a model naphthenic acid by nitrilotriacetic acid-Modified Fenton process. Chem. Eng. J. 2016, 292, 340-347. [CrossRef]

27. Zhu, C.; Zhu, F.; Wang, F.; Gao, J.; Fan, G.; Zhou, D.; Fang, G. Comparison of Persulfate Activation and Fenton Reaction in Remediating an Organophosphorus Pesticides-Polluted Soil. Pedosphere 2017, 27, 465-474. [CrossRef]

28. Usman, M.; Hanna, K.; Haderlein, S. Fenton oxidation to remediate PAHs in contaminated soils: A critical review of major limitations and counter-strategies. Sci. Total Environ. 2016, 569-570, 179-190. [CrossRef] [PubMed]

29. Venny; Gan, S.; Ng, H.K. Current status and prospects of Fenton oxidation for the decontamination of persistent organic pollutants (POPs) in soils. Chem. Eng. J. 2012, 213, 295-317. [CrossRef]

30. Pouran, S.R.; Aziz, A.A.; Daud, W.M.A.W. Review on the main advances in photo-Fenton oxidation system for recalcitrant wastewaters. J. Ind. Eng. Chem. 2015, 21, 53-69. [CrossRef]

31. Bello, M.M.; Abdul Raman, A.A.; Asghar, A. A review on approaches for addressing the limitations of Fenton oxidation for recalcitrant wastewater treatment. Process. Saf. Environ. Prot. 2019, 126, 119-140. [CrossRef]

32. Clarizia, L.; Russo, D.; Di Somma, I.; Marotta, R.; Andreozzi, R. Homogeneous photo-Fenton processes at near neutral pH: A review. Appl. Catal. B Environ. 2017, 209, 358-371. [CrossRef]

33. Catrouillet, C.; Davranche, M.; Dia, A.; Coz, M.B.-L.; Marsac, R.; Pourret, O.; Gruau, G. Geochemical modeling of Fe(II) binding to humic and fulvic acids. Chem. Geol. 2014, 372, 109-118. [CrossRef]

34. Siegrist, R.L.; Crimi, M.; Simpkin, T.J. In Situ Chemical Oxidation for Groundwater Remediation; Springer Science \& Business Media: Berlin, Germany, 2011; Volume 3.

35. Vicente, F.; Rosas, J.; Santos, A.; Romero, A. Improvement soil remediation by using stabilizers and chelating agents in a Fenton-like process. Chem. Eng. J. 2011, 172, 689-697. [CrossRef]

36. Dominguez, C.M.; Romero, A.; Checa-Fernandez, A.; Santos, A. Remediation of HCHs-contaminated sediments by chemical oxidation treatments. Sci. Total Environ. 2021, 751, 141754. [CrossRef]

37. Nam, K.; Rodriguez, W.; Kukor, J.J. Enhanced degradation of polycyclic aromatic hydrocarbons by biodegradation combined with a modified Fenton reaction. Chemosphere 2001, 45, 11-20. [CrossRef]

38. Liu, M.-H.; Hsiao, C.-M.; Wang, Y.-S.; Chen, W.-Y.; Hung, J.-M. Tandem modified Fenton oxidation and bioremediation to degrade lubricant-contaminated soil. Int. Biodeterior. Biodegrad. 2019, 143, 104738. [CrossRef]

39. Watts, R.J.; Stanton, P.C.; Howsawkeng, J.; Teel, A. Mineralization of a sorbed polycyclic aromatic hydrocarbon in two soils using catalyzed hydrogen peroxide. Water Res. 2002, 36, 4283-4292. [CrossRef]

40. Ahile, U.J.; Wuana, R.; Itodo, A.U.; Sha'Ato, R.; Dantas, R.F. A review on the use of chelating agents as an alternative to promote photo-Fenton at neutral pH: Current trends, knowledge gap and future studies. Sci. Total Environ. 2020, 710, 134872. [CrossRef] [PubMed]

41. Zhang, Y.; Zhou, M. A critical review of the application of chelating agents to enable Fenton and Fenton-like reactions at high pH values. J. Hazard. Mater. 2019, 362, 436-450. [CrossRef] [PubMed]

42. Leštan, D.; Luo, C.-L.; Li, X.-D. The use of chelating agents in the remediation of metal-contaminated soils: A review. Environ. Pollut. 2008, 153, 3-13. [CrossRef]

43. Gutteridge, J.M.C.; Maidt, L.; Poyer, L. Superoxide dismutase and Fenton chemistry. Reaction of ferric-EDTA complex and ferric-bipyridyl complex with hydrogen peroxide without the apparent formation of iron(II). Biochem. J. 1990, 269, 169-174. [CrossRef]

44. Sutton, H.C. Efficiency of chelated iron compounds as catalysts for the Haber-Weiss reaction. J. Free. Radic. Biol. Med. 1985, 1, 195-202. [CrossRef]

45. Kwan, C.; Chu, W. The role of organic ligands in ferrous-induced photochemical degradation of 2,4-dichlorophenoxyacetic acid. Chemosphere 2007, 67, 1601-1611. [CrossRef] [PubMed]

46. Zhang, Y.; Klamerth, N.; Messele, S.A.; Chelme-Ayala, P.; El-Din, M.G. Kinetics study on the degradation of a model naphthenic acid by ethylenediamine-N,N'-disuccinic acid-modified Fenton process. J. Hazard. Mater. 2016, 318, 371-378. [CrossRef] 
47. Huang, W.; Brigante, M.; Wu, F.; Mousty, C.; Hanna, K.; Mailhot, G. Assessment of the Fe(III)-EDDS Complex in Fenton-Like Processes: From the Radical Formation to the Degradation of Bisphenol A. Environ. Sci. Technol. 2013, 47, 1952-1959. [CrossRef]

48. He, J.; Yang, X.; Men, B.; Wang, D. Interfacial mechanisms of heterogeneous Fenton reactions catalyzed by iron-based materials: A review. J. Environ. Sci. 2016, 39, 97-109. [CrossRef] [PubMed]

49. Winterbourn, C.C. Chapter One-The Biological Chemistry of Hydrogen Peroxide. In Methods in Enzymology; Cadenas, E., Packer, L., Eds.; Academic Press: Cambridge, MA, USA, 2013; pp. 3-25.

50. Pardo, F.; Rosas, J.M.; Santos, A.; Romero, A. Remediation of soil contaminated by NAPLs using modified Fenton reagent: Application to gasoline type compounds. J. Chem. Technol. Biotechnol. 2014, 90, 754-764. [CrossRef]

51. Pardo, F.; Rosas, J.M.; Santos, A.; Romero, A. Remediation of a biodiesel blend-contaminated soil by using a modified Fenton process. Environ. Sci. Pollut. Res. 2014, 21, 12198-12207. [CrossRef]

52. Fischbacher, A.; von Sonntag, C.; Schmidt, T.C. Hydroxyl radical yields in the Fenton process under various $\mathrm{pH}$, ligand concentrations and hydrogen peroxide/Fe(II) ratios. Chemosphere 2017, 182, 738-744. [CrossRef]

53. Rachmilovich-Calis, S.; Masarwa, A.; Meyerstein, N.; Meyerstein, D. The effect of pyrophosphate, tripolyphosphate and ATP on the rate of the Fenton reaction. J. Inorg. Biochem. 2011, 105, 669-674. [CrossRef]

54. Wang, X.; Brusseau, M. Effect of pyrophosphate on the dechlorination of tetrachloroethene by the Fenton reaction. Environ. Toxicol. Chem. 1998, 17, 1689-1694. [CrossRef]

55. Venny; Gan, S.; Ng, H.K. Inorganic chelated modified-Fenton treatment of polycyclic aromatic hydrocarbon (PAH)-contaminated soils. Chem. Eng. J. 2012, 180, 1-8. [CrossRef]

56. Ma, X.-H.; Zhao, L.; Dong, Y.-H.; Chen, H.; Zhong, M. Enhanced Fenton degradation of polychlorinated biphenyls in capacitoroil-contaminated soil by chelating agents. Chem. Eng. J. 2018, 333, 370-379. [CrossRef]

57. Shih, Y.-J.; Binh, N.T.; Chen, C.-W.; Chen, C.-F.; Dong, C.-D. Treatability assessment of polycyclic aromatic hydrocarbons contaminated marine sediments using permanganate, persulfate and Fenton oxidation processes. Chemosphere 2016, 150, 294-303. [CrossRef] [PubMed]

58. Bennedsen, L.R.; Krischker, A.; Jørgensen, T.H.; Søgaard, E.G. Mobilization of metals during treatment of contaminated soils by modified Fenton's reagent using different chelating agents. J. Hazard. Mater. 2012, 199-200, 128-134. [CrossRef]

59. Sun, Y.; Zhao, L.; Teng, Y. Effect of soil type on the degradation of polychlorinated biphenyls in a pyrophosphate-chelated Fenton-like reaction. Chem. Eng. J. 2020, 390, 124574. [CrossRef]

60. Jiang, C.L.; Wang, X.H.; Parekh, B.K.; Leonard, J.W. Pyrite depression by phosphates in coal flotation. Min. Met. Explor. 1998, 15, 1-7. [CrossRef]

61. Richter, Y.; Fischer, B. Nucleotides and inorganic phosphates as potential antioxidants. JBIC J. Biol. Inorg. Chem. 2006, 11, 1063-1074. [CrossRef]

62. Khasawneh, F.; Hashimoto, I.; Sample, E. Reactions of ammonium ortho- and polyphosphate fertilizers in soil: II. Hydrolysis and reactions with soil. Soil Sci. Soc. Am. J. 1979, 43, 52-58. [CrossRef]

63. Biaglow, J.E.; Kachur, A.V. The generation of hydroxyl radicals in the reaction of molecular oxygen with polyphosphate complexes of ferrous ion. Radiat. Res. 1997, 148, 181. [CrossRef] [PubMed]

64. Zeng, B.; Zhang, P.; Zheng, M.; Xiao, N.; Han, J.; Wang, C.; Wang, Z.; Zhao, Z. Detection and identification of the oxidizing species generated from the physiologically important Fenton-like reaction of iron(II)-citrate with hydrogen peroxide. Arch. Biochem. Biophys. 2019, 668, 39-45. [CrossRef] [PubMed]

65. Lewis, S.; Lynch, A.; Bachas, L.; Hampson, S.; Ormsbee, L.; Bhattacharyya, D. Chelate-Modified Fenton Reaction for the Degradation of Trichloroethylene in Aqueous and Two-Phase Systems. Environ. Eng. Sci. 2009, 26, 849-859. [CrossRef] [PubMed]

66. Silva, A.M.N.; Kong, X.; Parkin, M.C.; Cammack, R.; Hider, R.C. Iron(iii) citrate speciation in aqueous solution. Dalton Trans. 2009, 2009, 8616-8625. [CrossRef] [PubMed]

67. Fujii, M.; Rose, A.L.; Waite, T.D.; Omura, T. Effect of divalent cations on the kinetics of Fe(III) complexation by organic ligands in natural waters. Geochim. Cosmochim. Acta 2008, 72, 1335-1349. [CrossRef]

68. Feng, X.; Wang, Z.; Chen, Y.; Tao, T.; Wu, F.; Zuo, Y. Effect of Fe(III)/Citrate Concentrations and Ratio on the Photoproduction of Hydroxyl Radicals: Application on the Degradation of Diphenhydramine. Ind. Eng. Chem. Res. 2012, 51, 7007-7012. [CrossRef]

69. Rush, J.; Maskos, Z.; Koppenol, W. Reactions of iron(II) nucleotide complexes with hydrogen peroxide. FEBS Lett. 1990, 261, 121-123. [CrossRef]

70. Zepp, R.G.; Faust, B.C.; Hoigne, J. Hydroxyl radical formation in aqueous reactions (pH 3-8) of iron(II) with hydrogen peroxide: The photo-Fenton reaction. Environ. Sci. Technol. 1992, 26, 313-319. [CrossRef]

71. Katsumata, H.; Kaneco, S.; Suzuki, T.; Ohta, K.; Yobiko, Y. Photo-Fenton degradation of alachlor in the presence of citrate solution. J. Photochem. Photobiol. A Chem. 2006, 180, 38-45. [CrossRef]

72. Chang, Y.-Y.; Roh, H.; Yang, J.-K. Improving the clean-up efficiency of field soil contaminated with diesel oil by the application of stabilizers. Environ. Technol. 2013, 34, 1481-1487. [CrossRef]

73. Rastogi, A.; Al-Abed, S.R.; Dionysiou, D.D. Effect of inorganic, synthetic and naturally occurring chelating agents on Fe(II) mediated advanced oxidation of chlorophenols. Water Res. 2009, 43, 684-694. [CrossRef]

74. Xu, J.; Xin, L.; Huang, T.; Chang, K. Enhanced bioremediation of oil contaminated soil by graded modified Fenton oxidation. J. Environ. Sci. 2011, 23, 1873-1879. [CrossRef] 
75. Georgi, A.; Schierz, A.; Trommler, U.; Horwitz, C.; Collins, T.; Kopinke, F.-D. Humic acid modified Fenton reagent for enhancement of the working $\mathrm{pH}$ range. Appl. Catal. B Environ. 2007, 72, 26-36. [CrossRef]

76. Wang, F.; Wu, Y.; Gao, Y.; Li, H.; Chen, Z. Effect of humic acid, oxalate and phosphate on Fenton-like oxidation of microcystin-LR by nanoscale zero-valent iron. Sep. Purif. Technol. 2016, 170, 337-343. [CrossRef]

77. Jeong, J.; Yoon, J. pH effect on OH radical production in photo/ferrioxalate system. Water Res. 2005, 39, 2893-2900. [CrossRef] [PubMed]

78. Park, J.S.B.; Wood, P.M.; Davies, M.J.; Gilbert, B.C.; Whitwood, A.C. A Kinetic and ESR Investigation of Iron(II) Oxalate Oxidation by Hydrogen Peroxide and Dioxygen as a Source of Hydroxyl Radicals. Free. Radic. Res. 1997, 27, 447-458. [CrossRef] [PubMed]

79. Xue, X.; Hanna, K.; Despas, C.; Wu, F.; Deng, N. Effect of chelating agent on the oxidation rate of $\mathrm{PCP}$ in the magnetite/ $\mathrm{H}_{2} \mathrm{O}_{2}$ system at neutral pH. J. Mol. Catal. A Chem. 2009, 311, 29-35. [CrossRef]

80. Evangelou, M.W.; Ebel, M.; Schaeffer, A. Chelate assisted phytoextraction of heavy metals from soil. Effect, mechanism, toxicity, and fate of chelating agents. Chemosphere 2007, 68, 989-1003. [CrossRef]

81. Sherwood, M.K.; Cassidy, D.P. Modified Fenton oxidation of diesel fuel in arctic soils rich in organic matter and iron. Chemosphere 2014, 113, 56-61. [CrossRef]

82. Martell, A.E.; Motekaitis, R.J.; Chen, D.; Hancock, R.D.; McManus, D. Selection of new Fe(III)/Fe(II) chelating agents as catalysts for the oxidation of hydrogen sulfide to sulfur by air. Can. J. Chem. 1996, 74, 1872-1879. [CrossRef]

83. Rush, J.D.; Koppenol, W.H. Oxidizing intermediates in the reaction of ferrous EDTA with hydrogen peroxide. Reactions with organic molecules and ferrocytochrome c. J. Biol. Chem. 1986, 261, 6730-6733. [CrossRef]

84. Ouriache, H.; Arrar, J.; Namane, A.; Bentahar, F. Treatment of petroleum hydrocarbons contaminated soil by Fenton like oxidation. Chemosphere 2019, 232, 377-386. [CrossRef]

85. Jorfi, S.; Rezaee, A.; Moheb-Ali, G.-A.; Jaafarzadeh, N.A. Pyrene removal from contaminated soils by modified Fenton oxidation using iron nano particles. J. Environ. Health Sci. Eng. 2013, 11, 17. [CrossRef]

86. Innocenti, I.; Verginelli, I.; Massetti, F.; Piscitelli, D.; Gavasci, R.; Baciocchi, R. Pilot-scale ISCO treatment of a MtBE contaminated site using a Fenton-like process. Sci. Total Environ. 2014, 485-486, 726-738. [CrossRef]

87. Piscitelli, D.; Zingaretti, D.; Verginelli, I.; Gavasci, R.; Baciocchi, R. The fate of MtBE during Fenton-like treatments through laboratory scale column tests. J. Contam. Hydrol. 2015, 183, 99-108. [CrossRef] [PubMed]

88. Xu, X.; Thomson, N.R. An evaluation of the green chelant EDDS to enhance the stability of hydrogen peroxide in the presence of aquifer solids. Chemosphere 2007, 69, 755-762. [CrossRef] [PubMed]

89. Oviedo, C.; Rodríguez, J. EDTA: The chelating agent under environmental scrutiny. Química Nova 2003, 26, 901-905. [CrossRef]

90. Rämö, J.; Sillanpää, M. Degradation of EDTA by hydrogen peroxide in alkaline conditions. J. Clean. Prod. 2001, 9, 191-195. [CrossRef]

91. Kołodyńska, D. Green complexing agent-EDDS in removal of heavy metal ions on strongly basic anion exchangers. Desalination 2011, 280, 44-57. [CrossRef]

92. Pinto, I.S.S.; Neto, I.F.F.; Soares, H. Biodegradable chelating agents for industrial, domestic, and agricultural applications-A review. Environ. Sci. Pollut. Res. 2014, 21, 11893-11906. [CrossRef] [PubMed]

93. Motekaitis, R.J.; Martell, A.E. The iron (III) and iron (II) complexes of nitrilotriacetic acid. J. Coordination Chem. 1994, 31, 67-78. [CrossRef]

94. Sun, S.-P.; Zeng, X.; Lemley, A.T. Kinetics and mechanism of carbamazepine degradation by a modified Fenton-like reaction with ferric-nitrilotriacetate complexes. J. Hazard. Mater. 2013, 252-253, 155-165. [CrossRef]

95. De Laat, J.; Dao, Y.H.; El Najjar, N.H.; Daou, C. Effect of some parameters on the rate of the catalysed decomposition of hydrogen peroxide by iron(III)-nitrilotriacetate in water. Water Res. 2011, 45, 5654-5664. [CrossRef]

96. Han, D.; Wan, J.; Ma, Y.; Wang, Y.; Huang, M.; Chen, Y.; Li, D.; Guan, Z.; Li, Y. Enhanced decolorization of Orange G in a Fe(II)-EDDS activated persulfate process by accelerating the regeneration of ferrous iron with hydroxylamine. Chem. Eng. J. 2014, 256, 316-323. [CrossRef]

97. Orama, M.; Saarinen, H.; Aksela, R. Complexation of [S,S] and mixed stereoisomers of $\mathrm{N}, \mathrm{N}^{\prime}$-ethylenediaminedisuccinic acid (EDDS) with Fe(III), Cu(II), Zn(II) and Mn(II) ions in aqueous solution. J. Chem. Soc. Dalton Trans. 2002, 24, 4644-4648. [CrossRef]

98. Han, D.; Wan, J.; Ma, Y.; Wang, Y.; Li, Y.; Li, D.; Guan, Z. New insights into the role of organic chelating agents in Fe(II) activated persulfate processes. Chem. Eng. J. 2015, 269, 425-433. [CrossRef]

99. Nahim-Granados, S.; Oller, I.; Malato, S.; Pérez, J.S.; Polo-Lopez, M. Commercial fertilizer as effective iron chelate (Fe ${ }^{3+}$-EDDHA) for wastewater disinfection under natural sunlight for reusing in irrigation. Appl. Catal. B Environ. 2019, 253, 286-292. [CrossRef]

100. Hayes, M.H.; Clapp, C.E. Humic substances: Considerations of compositions, aspects of structure, and environmental influences. Soil Sci. 2001, 166, 723-737. [CrossRef]

101. Zingaretti, D.; Lombardi, F.; Baciocchi, R. Soluble organic substances extracted from compost as amendments for Fenton-like oxidation of contaminated sites. Sci. Total Environ. 2018, 619-620, 1366-1374. [CrossRef] [PubMed]

102. Vione, D.; Merlo, F.; Maurino, V.; Minero, C. Effect of humic acids on the Fenton degradation of phenol. Environ. Chem. Lett. 2004, 2, 129-133. [CrossRef]

103. Wu, Y.; Zhou, S.; Ye, X.; Zhao, R.; Chen, D. Oxidation and coagulation removal of humic acid using Fenton process. Colloids Surf. A Physicochem. Eng. Asp. 2011, 379, 151-156. [CrossRef] 
104. Santos, A.; Rodríguez, S.; Pardo, F.; Romero, A. Use of Fenton reagent combined with humic acids for the removal of PFOA from contaminated water. Sci. Total Environ. 2016, 563-564, 657-663. [CrossRef] [PubMed]

105. Yang, B.; Cheng, X.; Zhang, Y.; Li, W.; Wang, J.; Tian, Z.; Du, E.; Guo, H. Staged assessment for the involving mechanism of humic acid on enhancing water decontamination using $\mathrm{H}_{2} \mathrm{O}_{2}-\mathrm{Fe}(\mathrm{III})$ process. J. Hazard. Mater. 2021, 407, 124853. [CrossRef]

106. Voelker, B.M.; Sulzberger, B. Effects of Fulvic Acid on Fe(II) Oxidation by Hydrogen Peroxide. Environ. Sci. Technol. 1996, 30, 1106-1114. [CrossRef]

107. Zingaretti, D.; Lominchar, M.A.; Verginelli, I.; Santos, A.; Baciocchi, R. Humic acids extracted from compost as amendments for Fenton treatment of diesel-contaminated soil. Environ. Sci. Pollut. Res. 2020, 27, 22225-22234. [CrossRef]

108. Zingaretti, D.; Lieto, A.; Lombardi, F.; Gavasci, R. Humic Substances Extracted from a Bio-stabilized Waste Applying Different Operating Conditions. Waste Biomass Valorization 2020, 11, 5283-5293. [CrossRef]

109. Xu, J.; Fan, X.; Huang, F.; Li, X. Iron bound to soil organic matter catalyzes $\mathrm{H}_{2} \mathrm{O}_{2}$ to oxidize crude oil in soil. J. Hazard. Mater. 2017, 322, 516-524. [CrossRef]

110. Jones, P.W.; Williams, D.R. Chemical speciation used to assess [S,S']-ethylenediaminedisuccinic acid (EDDS) as a readilybiodegradable replacement for EDTA in radiochemical decontamination formulations. Appl. Radiat. Isot. 2001, 54, 587-593. [CrossRef]

111. Schenkeveld, W.; Hoffland, E.; Reichwein, A.; Temminghoff, E.; van Riemsdijk, W. The biodegradability of EDDHA chelates under calcareous soil conditions. Geoderma 2012, 173-174, 282-288. [CrossRef]

112. Britton, H.T.S.; Robinson, R.A. CXCVIII.-Universal buffer solutions and the dissociation constant of veronal. J. Chem. Soc. 1931, 1456-1462. [CrossRef]

113. Faria, P.C.C.; Órfão, J.J.M.; Pereira, M.F.R. Activated carbon catalytic ozonation of oxamic and oxalic acids. Appl. Catal. B Environ. 2008, 79, 237-243. [CrossRef]

114. Lozano, J.; Rodríguez, P.B.; Tomé, F.V.; Calvo, C.P. Enhancing uranium solubilization in soils by citrate, EDTA, and EDDS chelating amendments. J. Hazard. Mater. 2011, 198, 224-231. [CrossRef]

115. Hseu, T.-M.; Wu, S.-T.; Lin, Z.-F. Stabilities and Thermodynamic Properties of Ethylenediamine-di(o-Hydroxyphenylacetic Acid) Chelates of Tripositive Lanthanide Ions. J. Chin. Chem. Soc. 1985, 32, 287-294. [CrossRef]

116. Tipping, E. Humic Ion-Binding Model VI: An Improved Description of the Interactions of Protons and Metal Ions with Humic Substances. Aquat. Geochem. 1998, 4, 3-47. [CrossRef]

117. Grzmil, B.U.; Kic, B. Pyro- and Tripolyphosphates and Citrates as the Complexing Agents for Micronutrients in Liquid Fertilizers. Ind. Eng. Chem. Res. 2002, 41, 139-144. [CrossRef]

118. Seol, Y.; Javandel, I. Citric acid-modified Fenton's reaction for the oxidation of chlorinated ethylenes in soil solution systems. Chemosphere 2008, 72, 537-542. [CrossRef] [PubMed]

119. Chaney, R. Plants can utilize iron form Fe-N,N'-di-(2-hydroxybenzoyl)-ethylenediamine- $\mathrm{N}, \mathrm{N}^{\prime}$-diacetic acid, a ferric chelate with 10greater formation constant than Fe-EDDHA. J. Plant Nutr. 1988, 11, 1033-1050. [CrossRef]

120. Engelmann, M.D.; Bobier, R.T.; Hiatt, T.; Cheng, I.F. Variability of the Fenton reaction characteristics of the EDTA, DTPA, and citrate complexes of iron. BioMetals 2003, 16, 519-527. [CrossRef] [PubMed]

121. Kolodynska, D. Chelating Agents of a New Generation as an Alternative to Conventional Chelators for Heavy Metal Ions Removal from Different Waste Waters. In Expanding Issues in Desalination; InTech Publishers: Gdańsk, Poland, 2011 ; pp. 339-370. [CrossRef]

122. Bataineh, H.; Pestovsky, O.; Bakac, A. pH-induced mechanistic changeover from hydroxyl radicals to iron (IV) in the Fenton reaction. Chem. Sci. 2012, 3, 1594-1599. [CrossRef]

123. Wang, Z.; Qiu, W.; Pang, S.; Jiang, J. Effect of chelators on the production and nature of the reactive intermediates formed in Fe(II) activated peroxydisulfate and hydrogen peroxide processes. Water Res. 2019, 164, 114957. [CrossRef]

124. Yoshimi, K.; Ryoji, o.; Niro, M. Oxygen Oxidation of Ferrous Ions Induced by Chelation. Bull. Chem. Soc. Jpn. 1968, 41, 2234-2239.

125. Melton, J.D.; Bielski, B.H. Studies of the kinetic, spectral and chemical properties of Fe(IV) pyrophosphate by pulse radiolysis. Int. J. Radiat. Appl. Instrumentation. Part. C Radiat. Phys. Chem. 1990, 36, 725-733. [CrossRef]

126. Buxton, G.V.; Greenstock, C.L.; Helman, W.P.; Ross, A.B. Critical Review of rate constants for reactions of hydrated electrons, hydrogen atoms and hydroxyl radicals $(\mathrm{OH} / \mathrm{O}-$ in Aqueous Solution. J. Phys. Chem. Ref. Data 1988, 17, 513-886. [CrossRef]

127. Shih, Y.-J.; Chen, K.-H.; Huang, Y.-H. Mineralization of organic acids by the photo-electrochemical process in the presence of chloride ions. J. Taiwan Inst. Chem. Eng. 2014, 45, 962-966. [CrossRef]

128. Sedlak, D.L.; Hoigné, J. The role of copper and oxalate in the redox cycling of iron in atmospheric waters. Atmos. Environ. Part. A Gen. Top. 1993, 27, 2173-2185. [CrossRef]

129. Lati, J.; Meyerstein, D. Oxidation of first-row bivalent transition-metal complexes containing ethylenediaminetetra-acetate and nitrilotriacetate ligands by free radicals: A pulse-radiolysis study. J. Chem. Soc. Dalton Trans. 1978, 1978, 1105-1118. [CrossRef]

130. Lutze, H.V.; Bircher, S.; Rapp, I.; Kerlin, N.; Bakkour, R.; Geisler, M.; Von Sonntag, C.; Schmidt, T.C. Degradation of Chlorotriazine Pesticides by Sulfate Radicals and the Influence of Organic Matter. Environ. Sci. Technol. 2015, 49, 1673-1680. [CrossRef] [PubMed]

131. Jonsson, S.; Persson, Y.; Frankki, S.; van Bavel, B.; Lundstedt, S.; Haglund, P.; Tysklind, M. Degradation of Polycyclic Aromatic Hydrocarbons (PAHs) in Contaminated Soils by Fenton's Reagent: A Multivariate Evaluation of the Importance of Soil Characteristics and PAH Properties. J. Hazard. Mater. 2007, 149, 86-96. [CrossRef] 
132. Sun, H.-W.; Yan, Q.-S. Influence of Fenton oxidation on soil organic matter and its sorption and desorption of pyrene. J. Hazard. Mater. 2007, 144, 164-170. [CrossRef]

133. Romero, A.; Santos, A.; Cordero, T.; Rodríguez-Mirasol, J.; Rosas, J.M.; Vicente, F. Soil remediation by Fenton-like process: Phenol removal and soil organic matter modification. Chem. Eng. J. 2011, 170, 36-43. [CrossRef]

134. Rosas, J.; Vicente, F.; Santos, A.; Romero, A. Enhancing p-cresol extraction from soil. Chemosphere 2011, 84, 260-264. [CrossRef]

135. Vicente, F.; Santos, A.; Sagüillo, E.G.; Martínez-Villacorta, Á.M.; Rosas, J.; Romero, A. Diuron abatement in contaminated soil using Fenton-like process. Chem. Eng. J. 2012, 183, 357-364. [CrossRef]

136. Criquet, J.; Nebout, P.; Leitner, N.K.V. Enhancement of carboxylic acid degradation with sulfate radical generated by persulfate activation. Water Sci. Technol. 2010, 61, 1221-1226. [CrossRef] [PubMed]

137. Lemaire, J.; Buès, M.; Kabeche, T.; Hanna, K.; Simonnot, M.-O. Oxidant selection to treat an aged PAH contaminated soil by in situ chemical oxidation. J. Environ. Chem. Eng. 2013, 1, 1261-1268. [CrossRef]

138. Yang, Y.; Ratté, D.; Smets, B.F.; Pignatello, J.J.; Grasso, D. Mobilization of soil organic matter by complexing agents and implications for polycyclic aromatic hydrocarbon desorption. Chemosphere 2001, 43, 1013-1021. [CrossRef]

139. Peluffo, M.; Mora, V.C.; Morelli, I.S.; Rosso, J.A. Persulfate treatments of phenanthrene-contaminated soil: Effect of the application parameters. Geoderma 2018, 317, 8-14. [CrossRef]

140. Hernández-Apaolaza, L.; Lucena, J.J. Influence of the Soil/Solution Ratio, Interaction Time, and Extractant on the Evaluation of Iron Chelate Sorption/Desorption by Soils. J. Agric. Food Chem. 2011, 59, 2493-2500. [CrossRef] [PubMed]

141. Cantera, R.G.; Zamarreño, A.M.; García-Mina, J.M. Characterization of Commercial Iron Chelates and Their Behavior in an Alkaline and Calcareous Soil. J. Agric. Food Chem. 2002, 50, 7609-7615. [CrossRef]

142. Siebner-Freibach, H.; Hadar, Y.; Chen, Y. Interaction of iron chelating agents with clay minerals. Soil Sci. Soc. Am. J. 2004, 68, 470-480. [CrossRef]

143. Rosas, J.M.; Vicente, F.; Sagüillo, E.G.; Santos, A.; Romero, A. Remediation of soil polluted with herbicides by Fenton-like reaction: Kinetic model of diuron degradation. Appl. Catal. B Environ. 2014, 144, 252-260. [CrossRef]

144. Chen, H.-Y. Why the Reactive Oxygen Species of the Fenton Reaction Switches from Oxoiron(IV) Species to Hydroxyl Radical in Phosphate Buffer Solutions? A Computational Rationale. ACS Omega 2019, 4, 14105-14113. [CrossRef] [PubMed]

145. Han, L.; Siekmann, F.; Zetzsch, C. Rate Constants for the Reaction of OH Radicals with Hydrocarbons in a Smog Chamber at Low Atmospheric Temperatures. Atmosphere 2018, 9, 320. [CrossRef]

146. Rosenfeldt, E.J.; Linden, K.G. Degradation of Endocrine Disrupting Chemicals Bisphenol A, Ethinyl Estradiol, and Estradiol during UV Photolysis and Advanced Oxidation Processes. Environ. Sci. Technol. 2004, 38, 5476-5483. [CrossRef] [PubMed]

147. Mandal, S. Reaction Rate Constants of Hydroxyl Radicals with Micropollutants and Their Significance in Advanced Oxidation Processes. J. Adv. Oxid. Technol. 2018, 21, 178-195. [CrossRef]

148. Haag, W.R.; Yao, C.C.D. Rate constants for reaction of hydroxyl radicals with several drinking water contaminants. Environ. Sci. Technol. 1992, 26, 1005-1013. [CrossRef]

149. Carvalho, M.; da Motta, M.; Benachour, M.; Sales, D.C.S.; Abreu, C. Evaluation of BTEX and phenol removal from aqueous solution by multi-solute adsorption onto smectite organoclay. J. Hazard. Mater. 2012, 239-240, 95-101. [CrossRef]

150. Ossai, I.C.; Ahmed, A.; Hassan, A.; Hamid, F.S. Remediation of soil and water contaminated with petroleum hydrocarbon: A review. Environ. Technol. Innov. 2020, 17, 100526. [CrossRef]

151. Killian, P.F.; Bruell, C.J.; Liang, C.; Marley, M.C. Iron (II) Activated Persulfate Oxidation of MGP Contaminated Soil. Soil Sediment. Contam. Int. J. 2007, 16, 523-537. [CrossRef]

152. Liang, C.; Huang, C.-F.; Chen, Y.-J. Potential for activated persulfate degradation of BTEX contamination. Water Res. 2008, 42, 4091-4100. [CrossRef]

153. Yap, C.L.; Gan, S.; Ng, H.K. Fenton based remediation of polycyclic aromatic hydrocarbons-contaminated soils. Chemosphere 2011, 83, 1414-1430. [CrossRef]

154. Abdel-Shafy, H.I.; Mansour, M. A review on polycyclic aromatic hydrocarbons: Source, environmental impact, effect on human health and remediation. Egypt. J. Pet. 2016, 25, 107-123. [CrossRef]

155. Sø, H.U.; Postma, D.; Jakobsen, R.; Larsen, F. Sorption of phosphate onto calcite; results from batch experiments and surface complexation modeling. Geochim. Cosmochim. Acta 2011, 75, 2911-2923. [CrossRef]

156. Zhao, D.; Liao, X.; Yan, X.; Huling, S.G.; Chai, T.; Tao, H. Effect and mechanism of persulfate activated by different methods for PAHs removal in soil. J. Hazard. Mater. 2013, 254-255, 228-235. [CrossRef]

157. Peluffo, M.; Rosso, J.A.; Morelli, I.S.; Mora, V.C. Strategies for oxidation of PAHs in aged contaminated soil by batch reactors. Ecotoxicol. Environ. Saf. 2018, 151, 76-82. [CrossRef]

158. Ferrarese, E.; Andreottola, G.; Oprea, I.A. Remediation of PAH-contaminated sediments by chemical oxidation. J. Hazard. Mater. 2008, 152, 128-139. [CrossRef] [PubMed]

159. Gryzenia, J.; Cassidy, D.; Hampton, D. Production and accumulation of surfactants during the chemical oxidation of PAH in soil. Chemosphere 2009, 77, 540-545. [CrossRef] [PubMed]

160. Paixão, I.; López-Vizcaíno, R.; Solano, A.; Martínez-Huitle, C.; Navarro, V.; Rodrigo, M.; Dos Santos, E. Electrokinetic-Fenton for the remediation low hydraulic conductivity soil contaminated with petroleum. Chemosphere 2020, 248, 126029. [CrossRef] [PubMed] 
161. Popescu, M.; Rosales, E.; Sandu, C.; Meijide, J.; Pazos, M.; Lazar, G.; Sanromán, M.A. Soil flushing and simultaneous degradation of organic pollutants in soils by electrokinetic-Fenton treatment. Process. Saf. Environ. Prot. 2017, 108, 99-107. [CrossRef]

162. Polli, F.; Zingaretti, D.; Crognale, S.; Pesciaroli, L.; D'Annibale, A.; Petruccioli, M.; Baciocchi, R. Impact of the Fenton-like treatment on the microbial community of a diesel-contaminated soil. Chemosphere 2018, 191, 580-588. [CrossRef]

163. Kakosová, E.; Hrabák, P.; Černík, M.; Novotný, V.; Czinnerová, M.; Trögl, J.; Popelka, J.; Kuráň, P.; Zoubková, L.; Vrtoch, L. Effect of various chemical oxidation agents on soil microbial communities. Chem. Eng. J. 2017, 314, 257-265. [CrossRef]

164. Watts, R.J.; Dilly, S.E. Evaluation of iron catalysts for the Fenton-like remediation of diesel-contaminated soils. J. Hazard. Mater. 1996, 51, 209-224. [CrossRef]

165. Gong, X.-B. Remediation of weathered petroleum oil-contaminated soil using a combination of biostimulation and modified Fenton oxidation. Int. Biodeterior. Biodegrad. 2012, 70, 89-95. [CrossRef]

166. Guzmán-López, O.; Cuevas-Díaz, M.D.C.; Toledo, A.M.; Contreras-Morales, M.E.; Ruiz-Reyes, C.I.; Martínez, A. del C.O. Fenton-biostimulation sequential treatment of a petroleum-contaminated soil amended with oil palm bagasse (Elaeis guineensis). Chem. Ecol. 2021, 1-16. [CrossRef]

167. Ko, S.; Crimi, M.; Marvin, B.K.; Holmes, V.; Huling, S.G. Comparative study on oxidative treatments of NAPL containing chlorinated ethanes and ethenes using hydrogen peroxide and persulfate in soils. J. Environ. Manag. 2012, 108, 42-48. [CrossRef] [PubMed]

168. Tan, C.; Gao, N.; Chu, W.; Li, C.; Templeton, M.R. Degradation of diuron by persulfate activated with ferrous ion. Sep. Purif. Technol. 2012, 95, 44-48. [CrossRef]

169. Deng, J.; Shao, Y.; Gao, N.; Deng, Y.; Tan, C.; Zhou, S. Zero-valent iron/persulfate(Fe0/PS) oxidation acetaminophen in water. Int. J. Environ. Sci. Technol. 2013, 11, 881-890. [CrossRef]

170. Lee, C.; Sedlak, D.L. A novel homogeneous Fenton-like system with Fe(III)-phosphotungstate for oxidation of organic compounds at neutral $\mathrm{pH}$ values. J. Mol. Catal. A Chem. 2009, 311, 1-6. [CrossRef]

171. Zhang, L.; Zeng, H.; Zeng, Y.; Zhang, Z.; Zhao, X. Heterogeneous Fenton-like degradation of 4-chlorophenol using a novel FeIII-containing polyoxometalate as the catalyst. J. Mol. Catal. A Chem. 2014, 392, 202-207. [CrossRef]

172. Lee, C.; Keenan, C.R.; Sedlak, D.L. Polyoxometalate-Enhanced Oxidation of Organic Compounds by Nanoparticulate Zero-Valent Iron and Ferrous Ion in the Presence of Oxygen. Environ. Sci. Technol. 2008, 42, 4921-4926. [CrossRef]

173. Chen, H.; Zhang, L.; Zeng, H.; Yin, D.; Zhai, Q.; Zhao, X.; Li, J. Highly active iron-containing silicotungstate catalyst for heterogeneous Fenton oxidation of 4-chlorophenol. J. Mol. Catal. A Chem. 2015, 406, 72-77. [CrossRef]

174. Lee, J.; Kim, J.; Choi, W. Oxidation on Zerovalent Iron Promoted by Polyoxometalate as an Electron Shuttle. Environ. Sci. Technol. 2007, 41, 3335-3340. [CrossRef] [PubMed]

175. Zhang, C.; Li, T.; Zhang, J.; Yan, S.; Qin, C. Degradation of p-nitrophenol using a ferrous-tripolyphosphate complex in the presence of oxygen: The key role of superoxide radicals. Appl. Catal. B Environ. 2019, 259, 118030. [CrossRef]

176. Deng, F.; Qiu, S.; Zhu, Y.; Zhang, X.; Yang, J.; Ma, F. Tripolyphosphate-assisted electro-Fenton process for coking wastewater treatment at neutral pH. Environ. Sci. Pollut. Res. 2019, 26, 11928-11939. [CrossRef] [PubMed]

177. Yehia, F.; Eshaq, G.; ElMetwally, A. Enhancement of the working $\mathrm{pH}$ range for degradation of p-nitrophenol using $\mathrm{Fe}^{2+}-\mathrm{aspartate}$ and $\mathrm{Fe}^{2+}$-glutamate complexes as modified Fenton reagents. Egypt. J. Pet. 2016, 25, 239-245. [CrossRef]

178. Li, Y.C.; Bachas, L.; Bhattacharyya, D. Kinetics Studies of Trichlorophenol Destruction by Chelate-Based Fenton Reaction. Environ. Eng. Sci. 2005, 22, 756-771. [CrossRef] 